(2.) ENERGY

Prepared for the U.S. Department of Energy

under Contract DE-AC05-76RL01830

RESULTS OF THE EXCRETA

BIOASSAY QUALITY CONTROL

PROGRAM FOR APRIL 1, 2007

THROUGH MARCH 31, 2008

\title{
CL Antonio
}

December 2008 


\title{
DISCLAIMER
}

This report was prepared as an account of work sponsored by an agency of the United States Government. Neither the United States Government nor any agency thereof, nor Battelle Memorial Institute, nor any of their employees, makes any warranty, express or implied, or assumes any legal liability or responsibility for the accuracy, completeness, or usefulness of any information, apparatus, product, or process disclosed, or represents that its use would not infringe privately owned rights. Reference herein to any specific commercial product, process, or service by trade name, trademark, manufacturer, or otherwise does not necessarily constitute or imply its endorsement, recommendation, or favoring by the United States Government or any agency thereof, or Battelle Memorial Institute. The views and opinions of authors expressed herein do not necessarily state or reflect those of the United States Government or any agency thereof.

\author{
PACIFIC NORTHWEST NATIONAL LABORATORY \\ operated by \\ BATTELLE \\ for the \\ UNITED STATES DEPARTMENT OF ENERGY \\ under Contract DE-AC05-76RL01830
}

Printed in the United States of America
Available to DOE and DOE contractors from the Office of Scientific and Technical Information,
P.O. Box 62, Oak Ridge, TN 37831-0062;
ph: (865) 576-8401
fax: $(865)$ 576-5728
email: reports@adonis.osti.gov

\begin{abstract}
Available to the public from the National Technical Information Service, U.S. Department of Commerce, 5285 Port Royal Rd., Springfield, VA 22161 ph: (800) 553-6847 fax: $(703) 605-6900$ email: orders@ntis.fedworld.gov online ordering: http://www.ntis.gov/ordering.htm
\end{abstract}

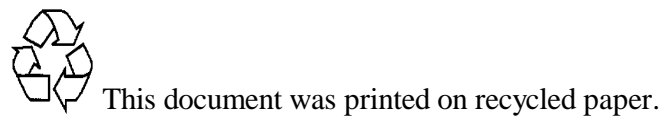


RESULTS OF THE EXCRETA BIOASSAY

QUALITY CONTROL PROGRAM FOR

APRIL 1, 2007 THROUGH MARCH 31, 2008

Cheryl L. Antonio

December 2008

Peer Reviewed by

Jay MacLellan

Date 


\section{$\underline{\text { SUMMARY }}$}

A total of 79 urine samples, 3 blank fecal and 5 spiked artificial fecal samples were submitted during the report period (April 1, 2007 through March 31, 2008) to General Engineering Laboratorics, South Carolina by the Hanford Internal Dosimetry Program (IDP) to check the accuracy, precision, and detection levels of their analyses. Urine analyses for tritium, $\mathrm{Sr},{ }^{23 \times} \mathrm{Pu},{ }^{2319} \mathrm{Pu},{ }^{241} \mathrm{Am},{ }^{243} \mathrm{Am}{ }^{235} \mathrm{U},{ }^{238} \mathrm{U}$, elemental uranium and fecal analyses for ${ }^{241} \mathrm{Am},{ }^{2.3} \mathrm{Pu}$ and ${ }^{239} \mathrm{Pu}$ were tested this year. The number of $\mathrm{QC}$ urine samples submitted during the report period represented $1.8 \%$ of the total simples submitted.

In addition to the samples provided by IDP, GEL was also requircd to conduct their own QC program, and submit the results of analyses to IDP. About $35 \%$ of the analyses processed by GEL during the third year of this contract were guality control samples. GEL tested the performance of 24 radioisotopes, all of which met or exceded the specifications in the Statement of Work within statistical uncertainty (Table 4).

IDP concluded that GEL was performing well for all analyses tested, and concerns identified earlier were satisfactorily resolved (see section on Follow-up on Concerns During the Third Contract Year)

The isotopic uranium analysis reports on three uranium isotopes: ${ }^{234} \mathrm{U},{ }^{235} \mathrm{U}$, and ${ }^{238} \mathrm{U}$. The isotopes are differentiated only during counting by alpha spectrometry. GEL reported that the calculated minimum detectable activity (MDA) for ${ }^{233.234} \mathrm{U}$ for the year slightly exceeded tic contract required detection limit. The MDA reported by GEL was within statistical uncertainty and determined to be acceptable.

Becatuse IDP used a depleted uranium source mitterial for the isotopic uranium urinalyses, ${ }^{233.234} \mathrm{U}$ was not evaluated. However, the performance statistics for ${ }^{235} \mathrm{U}$ and ${ }^{238} \mathrm{U}$ were reviewed and the MDA for ${ }^{235} \mathrm{U}$ and the bias and precision for ${ }^{238} \mathrm{U}$ were acceptable.

No concerns were identified with the clemental uranium urinalysis program and it was considered acceptable. Bccause IDP uses a $0.2 \mu \mathrm{g}$ screening level for elemental uranium, samples spiked at $0.06 \mu \mathrm{g}$ were discontinued. The MDA at the contractual level of $0.06 \mu \mathrm{g}$ was evaluated through GEL's program and were found to be acceptable. The relative bias was within statistical uncertainty and the relative precision was acceptable. The bias and 
precision as tested by IDP met the acceptance criteria. The bias and precision was tested by IDP at $0.2 \mu \mathrm{g}$ and by GEL at $1 \mu \mathrm{g}$ and at $0.06 \mu \mathrm{g}$.

The total strontium procedure is used to screen samples to determine which will require analysis for ${ }^{\% 0} \mathrm{Sr}$. Samples with total strontium results less than $15 \mathrm{dpm}$ do not undergo further analysis. Samples with results greater than or equal to $15 \mathrm{dpm}$ may undergo ${ }^{10} \mathrm{Y}$ in growth to specifically determine ${ }^{90} \mathrm{Sr}$ levels. The calculated MDA, as reported by GEL, for the total strontium part of the analysis was about $28 \%$ of the CL. The relative bias and precision, tested by IDP and GEL for the ${ }^{1 / 6} \mathrm{Sr}$ and total $\mathrm{Sr}$ procedures were all within limits. The 20 samples spiked at the contractual level by IDP were all detected. The strontium urinalysis procedure was concluded to be acceptable.

Samples spiked with ${ }^{238} \mathrm{Pu}$ and ${ }^{239} \mathrm{Pu}$ were analyzed using the same procedures and same reagents. The two isotopes are differentiated only at the end of the procedure by alpha spectrometry. Therefore, laboratory performance is expected to be similar for both isotopes using any of the seven procedures that incorporate plutonium analysis (IPU, IPA, IPS, IPSA, IPSR, IUPU, and ITPAC).

The MDAs and performance statistics for ${ }^{236} \mathrm{Pu}$ and ${ }^{238} \mathrm{Pu}$ in urine were acceptable. The 33 samples spiked at the $\mathrm{CL}$ for ${ }^{239} \mathrm{Pu}$ were reported with only onc result less than the decision level indicating a $3 \%$ false negative. There were four blank sumples indicating ${ }^{238} \mathrm{Pu}$ activity, one sample indicated activity in excess of the CL. Upon review it appears that the samples may have been cross-contaninated during handling in the audit laboratory. Results of the four samples were not removed from the data set because it could not be verified that the samples were contaminated. Including the four elevated samples, the MDA as analyzed by IDP for ${ }^{238} \mathrm{Pu}$ was only slightly elevated. GEL, reported an MDA for ${ }^{238} \mathrm{Pu}$ that was $50 \%$ of the CL. Overall the plutonium urinalyses were considered acceptable.

The MDA and performance statistics for ${ }^{239} \mathrm{Pu}$ and ${ }^{238} \mathrm{P} u$ in feces were acceptable. Approximately $15 \%$ of the fecal samples analyzed were duplicated to test the consistency of the alicpuoting procedure. A review of the duplicate samples determined that the aliquoting procedure produced results within 3 sigma of the initial results. The fecal aliquoting procedure was acceptable. None of the 7 blank ${ }^{238} \mathrm{Pu}$ or the 2 blank ${ }^{2.34} \mathrm{Pu}$ fecal analyses were greater than the decision level. There were no fecal samples spiked at the CL with ${ }^{238} \mathrm{Pu}$. The five fecal samples 
spiked with ${ }^{239} \mathrm{Pu}$ were reported with a result greater than the decision level. Overall the plutonium [ccal analyses were considered acceptable.

The ${ }^{2+1}$ Am fecal and urine analysis met the acceplance criteria for MDA, relative bias and precision. The MDA as reported by GEL was $50 \%$ of the contractual level. There were $25{ }^{24 I}$ Am samples spiked at the contractual detection level (CL) and 14 indicated activity between three to five times the CL. It was later determined that cross contamination of the samples occurred in the audit laboratory during spiking. A more detail discussion of the cross contamination is in the Am24l discussion section. The 14 data points were removed from the data set to evaluate the relative bias and precision, both of which met the acceptance criteria. GEL reported a slightly elevated precision for ${ }^{241} \mathrm{Am}$, but the results were within statistical uncertainty. The current AM241 arinalysis procedure was considered acceptable.

Both blank ${ }^{241}$ Am fecal samples were less than the decision level and the five spiked fecal samples were all greater than the decision. The ${ }^{241}$ Am fecal duplicate samples were evaluated and it was concluded that the aliquoting procedure produced results within the control limits.

The AM243 procedure was identical to the AM241 procedure, except a different tracer is used $\left({ }^{244} \mathrm{Cm}\right.$ instead of $\left.{ }^{243} \mathrm{Am}\right)$. The seven blank ${ }^{243} \mathrm{Am}$ QC samples submitted were all reported with results less than the decision level and the calculated MDA was $65 \%$ of the contractual detection level. The performance statistics for ${ }^{243} \mathrm{Am}$, as tested by GEL, met the acceptance criteria. The ${ }^{243} \mathrm{Am}$ procedure was concluded to be acceptable.

IDP did not submit QC samples to test the isotopic curium program, therefore performance statistics were based on the GEL QC results. GEL tested the MDA for ${ }^{242} \mathrm{Cm}$ and ${ }^{244} \mathrm{Cm}$ and the relative bias and precision for ${ }^{244} \mathrm{Cm}$. The results met the acceptance criteria and the isotopic curium urinalysis program was considered acceptable.

IDP also did not submit QC samples to test the isolopic thorium program, therefore performance statistics were based on the GEL QC results. GEL tested the MDA for ${ }^{228} \mathrm{Th},{ }^{229} \mathrm{Th}$, ${ }^{230} \mathrm{~T}$ Th and ${ }^{232}$ Th and the relative bias and precision for ${ }^{23} \mathrm{Th}$. The results met the acceptance criteria and the isotopic thorium urinalysis program was considered acceptable.

A new ${ }^{236} \mathrm{U}$ analysis procedure was initiated in June 2007 and one urinalysis was run. The analysis for ${ }^{236} \mathrm{U}$ uses an inductively coupled plasma mass spectrometry. A review of the ${ }^{236} \mathrm{U}$ analysis detemined that more work was needed in reducing uncertainties and improving the 
analysis. The procedure was not formally approved until June 2008 and will be discussed in the fourth contract year's report. 


\section{CONTENTS}

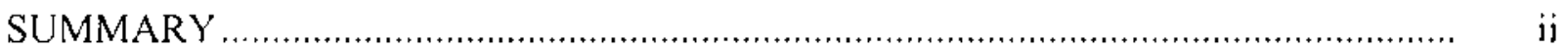

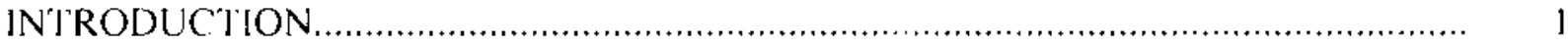

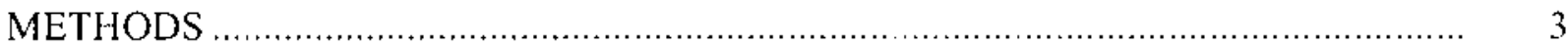

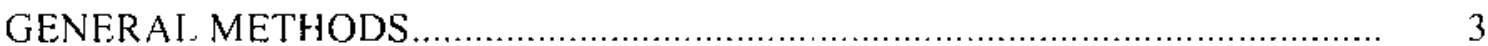

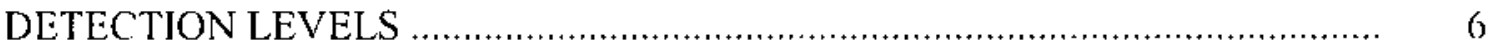

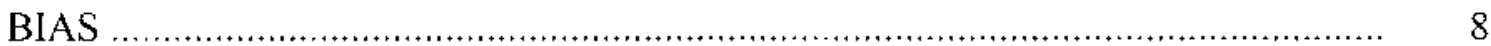

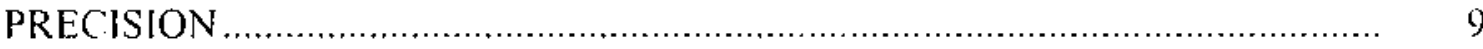

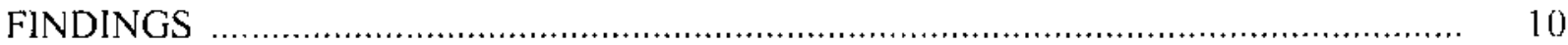

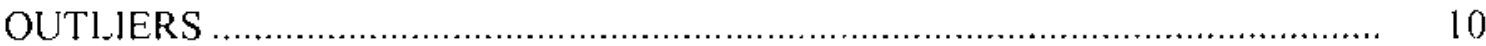

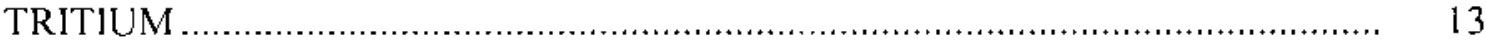

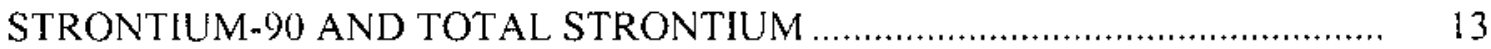

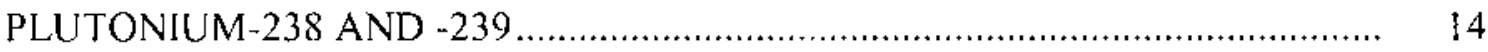

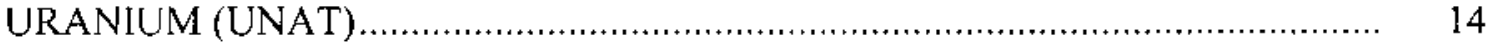

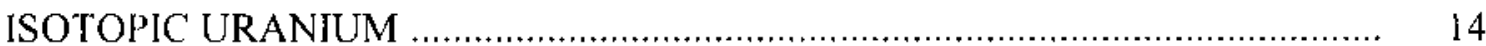

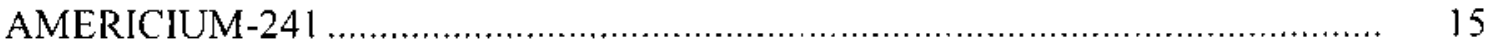

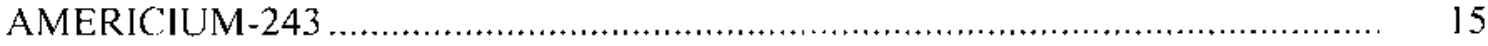

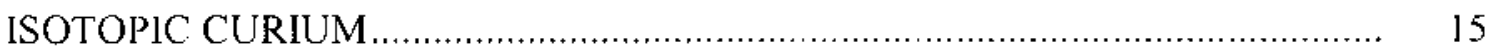

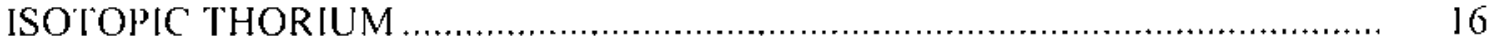

FOLLOW-UP ON CONCERNS DURING THE THIRD CONTRACT YEAR $\ldots \ldots \ldots \ldots \ldots . . . . \quad 16$

SUMMARY OF THE QUALITY CONTROL REPORT FROM GEL INCORPORATED, FOR THE CONTRACT 313500 FOURTH OPERATIONAL YEAR $\ldots \ldots \ldots \ldots \ldots \ldots \ldots \ldots \ldots \ldots \ldots$ RESULTS FROM INTERCOMPARISON PROGRAMS …..................................... 17

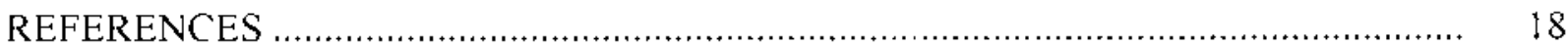

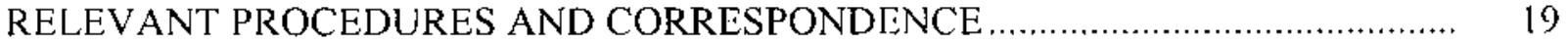

APPENDIX A QUALITY CONTROL SAMPLE RESULTS

(Historical File Only) 
APPENDIX B GEL QUALITY CONTROL REPORT SUMMARY

(Historical File Only)

APPENDIX C GEL DUPLICATES

(Historical File Only)

\section{AT'TACHMENT 1: AMERICIUM-241 CONTAMINATION INVESTIGATION}

(Historical File Only)

\section{TABLES}

1 Analytical and Reporting Requirements for Routine Processing of Samples.......... 4

2 Number and Category of Bioassay Samples Analyzed ................................... 5

3 Typical Chemical Yield, Typical Detector Efficiencies, and Counling Time Values

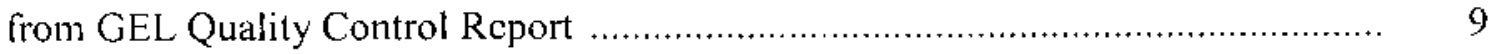

4 Summary of Statistical Values by Nuclide .............................................. 11

5 Comparison of Quality Control Statistics for 2001, 2002 and 2003 Reporting Periods

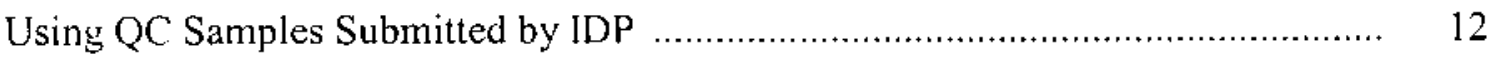

6 Other lndicators of Analytical Uncertainty .............................................. 13 


\section{INTRODUCTION}

This report summarizes the results of the excreta bioassay quality control program's monitoring of the performance of General Engineering Laboratories (GEL) for samples submitted from April 1, 2007 through March 31, 2008. During the reporting period GEL analyzed, under the contract with Battelle, 4621 urine and 98 fecal samples for various radionuclides. This is about the same workload as reported in the 2006 report.

The results of the analyses are part of a system of legal records concerning internal deposition of radionuclides for workers at the Hanford Site. GEL is required to have a rigorous quality control (QC) program to ensure the accuracy of its results. In addition, the Pacific Northwest National Laboratory's (PNNL) Hanford Internal Dosimetry Program (IDP) has a QC program in place to independently check the accuracy of the results from GEL. The objective of the PNNL excreta bioassay QC program is to provide quantitative data to support the assessment of performance criteria for excreta bioassay analyses, as specified in the Statement of Work (Battelle 2007).

The reliability of the excreta bioassay program depends, to a significant extent, on the adoption and implementation of performance criteria for laboratory accuracy, precision, and detection levels. Such performance criteria are established in the Statement of Work (Battelle 2007) and include the following:

- Actual minimum detectable activities (MDAs) determined from QC samples for the year shall be cqual to or less than the contrictual detection level (C.L) in the Statement of Work, as calculated from blank QC samples.

- The mean relative bias, $B_{r}$, shall fall within $\pm 20 \%$ when calculated from 15 to 50 samples spiked at greater than three times the $\mathrm{CL}$, and within $\pm 10 \%$ when calculated from greater than 50 samples. 
- The relative precision statistic, $\mathrm{S}_{\mathrm{B}}$, shall be less than or equal to 0.4 for samples spiked al greater than three times the CL, and less than or equal to 0.5 for samples spiked between one and three times the CL.

Formulas for MDA, $\mathrm{B}_{\mathrm{r}}$, and $\mathrm{S}_{\mathrm{B}}$, presented in the next section of this report, are based on recommendations in the Health Physics Society (HPS) Standard N13.30 (1996) and are listed in the Statement of Work. In addition to the Statement of Work (SOW) perfomance criteria, it is expected that the MDA shall also be such that fewer than $10 \%$ of the QC samples spiked at the $\mathrm{CL}$ shall be reported with values less than the decision level (i.e., twice the total propagated uncertainty of the result). 


\section{METHODS}

\section{GENERAL METHODS}

Urine collected from PNNL employees who are not occupationally exposed to radioactive material was prepared in the 325 Building as blank and spiked samples by PNNL Radiochemical Proccssing Group (RPG), according to the directions given by the PNNL Internal Dosimetry Program (IDP), following Procedure PNL-MA-565-800-20, Rev. 2. Most samples were submitted as double-blind samples, with the exception of isotopic uranium urinalyses and the spiked fecal samples. Double blind samples are scheduled with and collected by GEL as if they were personncl samples. The isotopic uranium urinalyses werc scheduled as single-blind intercomparisons, which meant that GEL was aware they were intercomparison samples but unaware of the activity. The samples were scheduled as single-blinds because they were spiked with a depleted uranium source. Since depleted uranium exposures at Hanford are rare, the intercomparison samples would stand out and the QC alias names used could bccome known and compromise the double-blind intercomparison program. The spiked fecal samples were artificial fecal samples consisting of a soil matrix. Blank fecal samples were scheduled as double-blind samples and were actual fecal samples.

GEL analyzed urine samples for tritium, ${ }^{90} \mathrm{Sr},{ }^{242} \mathrm{Cm},{ }^{244} \mathrm{Cm},{ }^{238} \mathrm{Pu},{ }^{234,240} \mathrm{Pu},{ }^{241} \mathrm{Pu}$ ${ }^{241} \mathrm{Am},{ }^{24.3} \mathrm{Am},{ }^{228} \mathrm{Th},{ }^{229} \mathrm{Th},{ }^{230} \mathrm{Th},{ }^{232} \mathrm{Th}{ }^{236} \mathrm{U},{ }^{234} \mathrm{U},{ }^{235} \mathrm{U},{ }^{238} \mathrm{U}$ and elemental uranium and fecal samples for ${ }^{238} \mathrm{Pu},{ }^{239.240} \mathrm{Pu},{ }^{241} \mathrm{Am},{ }^{234} \mathrm{U},{ }^{235} \mathrm{U},{ }^{238} \mathrm{U}$. To reduce costs in the intercomparison progran, plutonium, americium, and strontium analyses were tested using routine sequential procedures when possible (i.c., where one urine sample is analyzed for scveral radionuclides). The analysis categories specified in the contract with GEL are shown in Table 1. All urinalysis samples contained approximately $1000 \mathrm{ml}$ of urine, except for the samples analyzed for tritium, which contained approximately $100 \mathrm{ml}$.

GEL's QC sample total is dependent on the number of analytical batches run during the ear, and they were well over the $15 \%$ criteria specificd in the contract. 


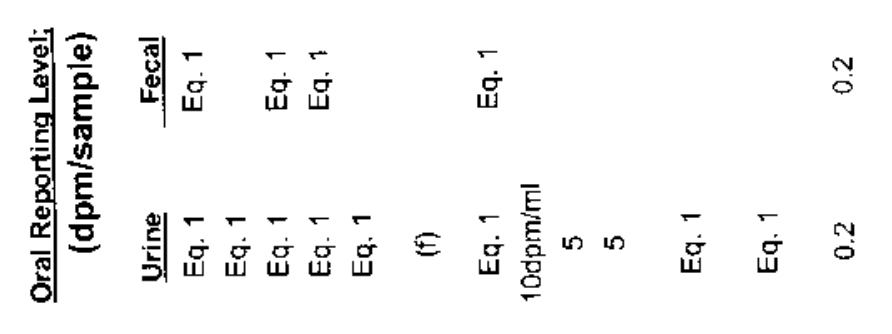

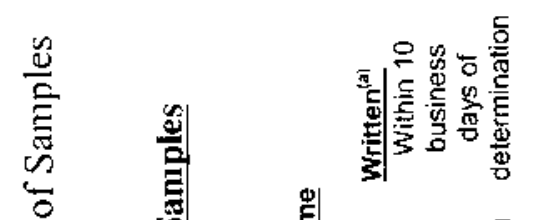

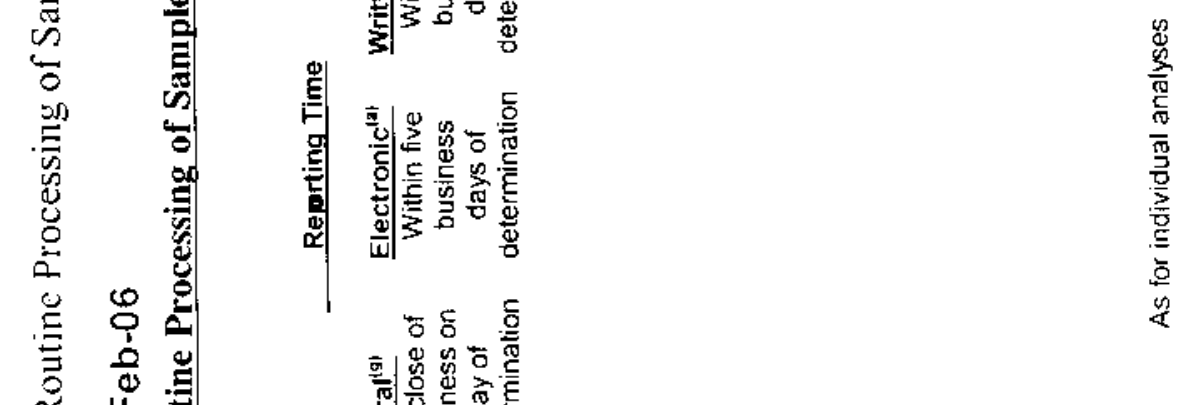

(1)

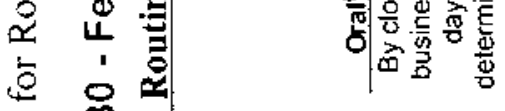

岁

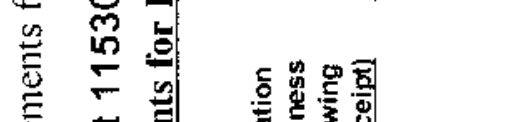

吾

을

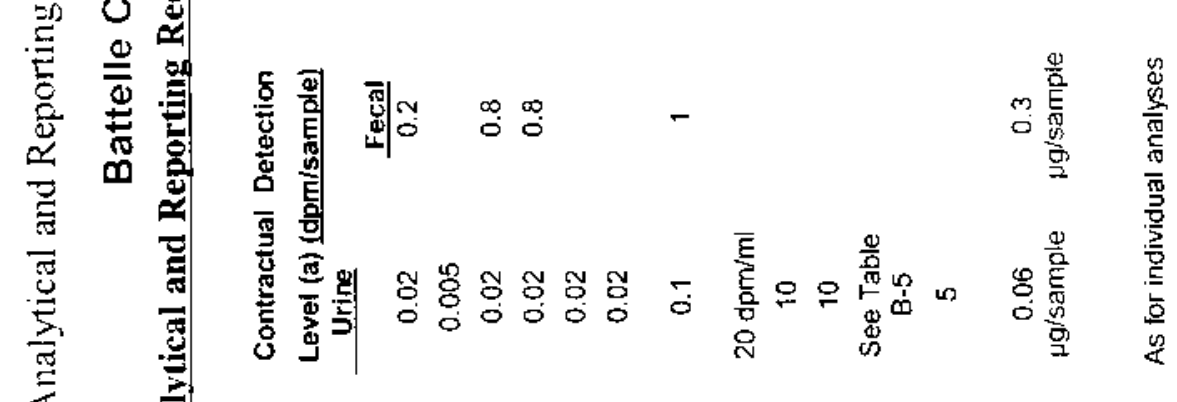

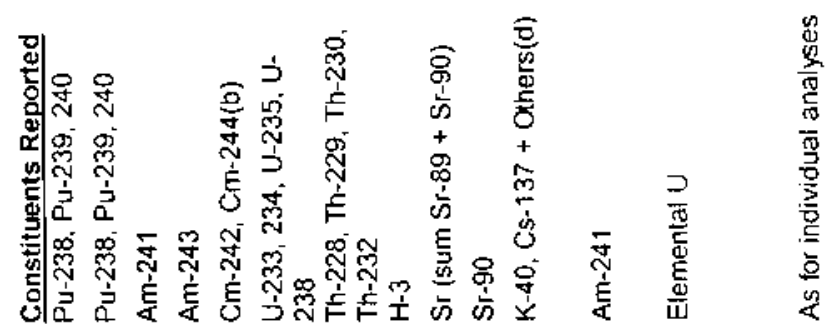


TABLE 2. Number and Category of Bioassay Samples Analyzed

\begin{tabular}{|c|c|c|c|c|c|c|c|c|}
\hline \multirow{2}{*}{$\begin{array}{l}\text { Procedure } \\
\text { Coude }\end{array}$} & \multicolumn{4}{|c|}{$\begin{array}{c}\text { SECOND CONTRACT YEAR - GEL } \\
\underline{4 / 1 / 06 \text { through } 3 / 31 / 07}\end{array}$} & \multicolumn{4}{|c|}{$\begin{array}{c}\text { THIRD CONTRAC' T YEAR - GEL } \\
\underline{4 / 1 / 07 \text { througl } 3 / 31 / 08}\end{array}$} \\
\hline & Total & $\mathrm{IDP} Q \mathrm{QC}$ & $\%$ & $\left(\mathrm{iEL} Q \mathrm{Q}^{-131}\right.$ & Total & IDP QC & $\%$ & GEI.QC ${ }^{(1)}$ \\
\hline \multicolumn{9}{|l|}{ Urine } \\
\hline $\mathrm{H} 3$ & 892 & 3 & 0.3 & 276 & 821 & 0 & 0.0 & 282 \\
\hline SR90, SR & 231 & 3 & 1.3 & 482 & 181 & 0 & 0.0 & 447 \\
\hline $\mathrm{Cl} 4$ & -- & -- & -- & -- & -- & -- & -- & $\cdots$ \\
\hline AM24l & 103 & -- & -- & 437 & 99 & -- & -- & 463 \\
\hline A.M 243 & 8.5 & 6 & 7.1 & 122 & 88 & 7 & 8.0 & 84 \\
\hline U235 & -- & -- & -- & -- & -- & -- & -- & 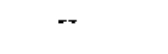 \\
\hline Ic $\mathrm{M}$ & 13 & -- & -- & 241 & 7 & -- & -- & \\
\hline IPU & 1243 & -- & -- & 1152 & 1401 & 9 & -- & 1261 \\
\hline l]UL & l & -- & -- & $\mathrm{N} / \mathrm{A}$ & 5 & -- & -- & -- \\
\hline$[\mathrm{P} A$ & 293 & 4 & 1.4 & $\mathrm{~N} / \mathrm{A}$ & 401 & 4 & 1.0 & $\mathrm{~N} / \mathrm{A}$ \\
\hline IPS & 553 & 2 & 0.4 & N/A & 481 & 0 & 0.0 & $\mathrm{~N} / \mathrm{A}$ \\
\hline IPSA & 152 & 15 & 9.9 & $\mathrm{~N} / \mathrm{A}$ & 158 & 20 & 12.7 & $\mathrm{~N} / \mathrm{A}$ \\
\hline IPSR & -- & - & -- & -- & -- & -- & -- & -- \\
\hline ISPEC & -- & -- & -- & -- & -- & $-\cdot$ & -- & -- \\
\hline ITPAC & 90 & -- & -- & $\mathrm{N} / \mathrm{A}$ & 116 & $\cdots$ & -- & N/A \\
\hline ITH & -- & -- & -- & - & 1 & -- & -- & 8 \\
\hline IL!PU & 108 & -- & .. & $\mathrm{N} / \mathrm{A}$ & 114 & -- & -- & $\mathrm{N} / \mathrm{A}$ \\
\hline [PIU & 4 & 1 & 25.0 & $\mathrm{~N} / \mathrm{A}$ & 10 & 0 & 0.0 & N/A \\
\hline [U] & 500 & 14 & 2.8 & 279 & 519 & 16 & 3.1 & 243 \\
\hline NP237 & -- & -. & -- & -- & -- & -- & - & - \\
\hline U236 & -- & $\cdots$ & -- & -- & 1 & -- & -- & 3 \\
\hline UNAT" & 235 & 18 & 7.7 & 339 & 218 & 23 & 10.6 & 402 \\
\hline LEPD & -- & -- & -- & -- & -- & . & -- & -- \\
\hline PU241 & - & -- & -- & -- & - & -- & -- & -- \\
\hline Trtal & 4503 & 66 & 1.5 & 3328 & 4621 & 79) & 1.7 & .3253 \\
\hline
\end{tabular}

\begin{tabular}{|c|c|c|c|c|c|}
\hline \multicolumn{6}{|l|}{ Fecal $I^{f()}$} \\
\hline U232 & -- & -- & -- & -- & $-\cdot$ \\
\hline ICM & 1 & -- & -- & -. & -- \\
\hline IL' & -- & -- & - & -- & 3 \\
\hline AM241 & 15 & -- & - & 133 & 4 \\
\hline [PU] & 12 & -- & - & 138 & 36 \\
\hline IPA & 83 & 12. & 14.5 & $\mathrm{~N} / \mathrm{A}$ & 55 \\
\hline Toral & 111 & 12 & 10.8 & 271 & 98 \\
\hline
\end{tabular}


Table 2 presents a breakdown of the numbers and categories for all bioassay samples analyzed, inciuding personnel and QC samples. From 79 urine and 8 fecal QC samples submitted by IDP to GEL during the reporting period, GEL reported 4621 analytical urine results for 13 different analytes and 98 fecal results for 4 different analytes. The 87 QC samples represent $1.8 \%$ of the total analyses performed by GEL. In addition to these samples, GEL analyzed 3,462 internal QC samples. The QC samples analyzed equaled $35 \%$ of the samples analyzed by GEL under their contract with Battelle.

GEL's performance was checked by determining detection level, bias, and precision based on the results of blank and spiked samples. Spiked samples fell into two categories: those spiked near the CL and those spiked at equal to or greater than three times the CL. These two categories were necessary to check compliance with the criteria for relative precision $\left(\mathrm{S}_{\mathrm{B}}\right)$ specified by the Statement of Work. Satisfying these wwo categories also verified that GEL could detect sample activities near the CL.

\section{DETECTION LEVELS}

Various mathematical expressions and terminology can be used to describe a detection level. The statistical approach specified in the Statement of Work basically follows that of Currie (1968) and HPS N13.30 (HPS 1996). However, the HPS N13.30 formulas were modified to account for the difference between a priori estimates of detection levels based on counts (Currie 1968) and a posteriori estimates based on total activity, where chemical yield is determined specifically for each sample.

Two test criteria were used: the decision level $\left(L_{c}\right)$ and the MDA (also called the detection level). The decision level was defined in the Statement of Work as the quantity of radioactivity or mass above which there is at least $95 \%$ confidence that the sample is not a blank (Type I error). If the measured value was greater than the $\mathrm{L}_{\mathfrak{c}}$, the sample was considered likely to contain the radionuclide of interest. If the measured value was less than $\mathrm{L}_{c}$, then the result was considered indistinguishable from a blank. The $\mathrm{L}_{\mathfrak{c}}$ was determined solely by measuring blank samples. Before the $\mathrm{L}_{\mathrm{c}}$ was calculated, results that were significant outliers were eliminated from the data set. Outliers were identified by the use of the criteria of ASTM E178-94 (ASTM 1994). 
Mathematically, $L_{c}$ is defined by the following equation:

$$
L_{c}=2 s_{\mathrm{A}}
$$

where, $s_{\wedge}$ equals the combined standard uncertainty of the net analyte reported.

The MDA was based on a $95 \%$ confidence in detecting activity when the actual activity was equal to the MDA. Conversely, the $95 \%$ confidence level is the point at which only $5 \%$ of the results for samples containing activity equal to the MDA fall below the $\mathrm{L}_{\mathrm{c}}$ and, thus, were judged to contain no activity (Type II error). The MDA, expressed in units of disintegrations per minute, is calculated from the same set of blanks as the $L_{c}$ (outliers excluded), using the following equation:

$$
\operatorname{MDA}=\overline{X_{11}}+2\left(t_{n-1}\right) s_{1:}+\frac{\left(t_{n-1}\right)^{2}}{\text { ERT }}
$$

where $E$ is the typical counter detection efficiency in counts per disintegration, $R$ is the average fractional chemical recovery or yield, and $\mathrm{T}$ is the typical counting time. In keeping with the philosophy of HPS N13.30, if $\mathrm{t}^{2}$ is less than 3 , then 3 is used instead. For elemental uranium analyses, the analytical method does not produce count data; the unit for the analysis result and MDA is micrograms. Thus, the "3" term is not an appropriate part of the equation for the elemental uranium analysis.

The present contract with GEL, implemented on April 1,2005 with GEL, specilies an operational year that ends March $31^{\text {st }}$, each year. This QC report covers the second operational year of that contract, and includes samples analyzed by GEL during period of April 1, 2006 through March 31, 2007.

The MDA values GEL calculates for their QC reports are based on mean values for parameters of equation 2 of the contract statement of work, and not replicate measurements. GEL also uses synthetic samples, whereas IDP uses real fecal and urine samples.

The IDP QC samples were evaluated by first calculating the $L_{\mathfrak{c}}$ from blank samples, excluding outliers. This $\mathrm{L}_{c}$ was compared with the $\mathrm{L}_{c}$ calculated from GEL's own QC samples. Then, the MDA was calculated and compared with the CL and the MDA calculated from GEL's own QC samples. Values used for $\mathrm{E}, \mathrm{R}$, and $\mathrm{T}$ in the MDA equation were obtained from the 
laboratory; they are listed in Table 3. Finally, the percentage of QC samples spiked at the CL that were measured by the laboratory as having less than the decision level (i.e., no activity was detected) was determined; this percentage was then compared with the 5\% allowed in the Statement of Work. Outliers were included in this test.

BIAS

Relative bias is defined as the mean fractional deviation of the reported results from the true values of spikes added to the samples. The formulas in the Statement of Work used to measure bias in sample results are the same as those in HPS N13.30 (1996). The mean relative bias, $\mathrm{Br}$, is detemined using:

$$
B_{r}=\sum_{i=1}^{H} \sum_{i=1}^{n} \frac{B_{r i j}}{N}
$$

where $n=$ number of spike samples in each level

$\mathrm{m}=$ number of spike levels

$\mathrm{N}=$ total number of spiked samples

$\mathrm{B}_{\mathrm{rij}}=$ bias of a single measurement, defined as:

$$
B_{r i j}=\frac{\left(A_{i j}-A_{u i}\right)}{A_{a i}}
$$

where

$$
A_{i j}=\text { the jth measured value of the ith spike level, }
$$

$A_{a i}=$ the true value of the ith spike level 
TABLE 3. Typical Chemical Yjeld (R), Typical Detector Efficiencies (E), and Counting Time (T) Values from GEL Quality Control Report

\begin{tabular}{|c|c|c|c|c|c|c|c|}
\hline \multirow[b]{2}{*}{ Matrix } & \multirow{2}{*}{$\begin{array}{l}\text { Nuclide/ } \\
\text { Method }\end{array}$} & \multirow{2}{*}{$\begin{array}{l}\text { Count } \\
\text { Minutes }\end{array}$} & \multirow{2}{*}{$\begin{array}{l}\text { Contract } \\
\text { Limit }^{\text {(ut }}\end{array}$} & \multicolumn{2}{|c|}{ Counter Efficiency } & \multicolumn{2}{|c|}{ Chentical Yicld } \\
\hline & & & & $2006-2007$ & $2007-2008$ & $2006-2007$ & $2007-2008$ \\
\hline \multirow[t]{12}{*}{ Urinc } & ${ }^{3} \mathrm{HI}$ & 20 & 20 & 0.18 & 0.24 & --- & -- \\
\hline & Total Sr & 60 & 10 & 0.396 & 0.379 & 0.774 & 0.788 \\
\hline & SR90 & 60 & 10 & --- & $\ldots$ & --- & --- \\
\hline & ${ }^{241} \mathrm{AIm}$ & 2520 & 0.02 & 0.385 & 0.391 & 0.725 & 0.816 \\
\hline & ${ }^{24.3} \mathrm{Am}$ & 2520 & 0.02 & 0.385 & 0.391 & 0.885 & 0.871 \\
\hline & $=-12 \mathrm{Cm} / 2+4+\mathrm{Cm}$ & 2520 & 0.02 & 0.385 & 0.391 & 0.725 & 0.816 \\
\hline & ${ }^{2.37} \mathrm{~Np}$ & 2520 & 0.02 & --- & -- & --- & $-\cdots$ \\
\hline & ${ }_{2.3 .13} \mathrm{Pu} /{ }^{234} \mathrm{Pu}$ & 2520 & 0.02 & 0.385 & 0.391 & 0.915 & 0.890 \\
\hline & IPUL & 10000 & 0.005 & --- & $\cdots$ & --- & --- \\
\hline & 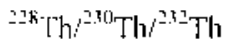 & 2520 & 0.1 & $\mathrm{NA}$ & 0.386 & NA & 0.880 \\
\hline & 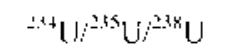 & 2520 & 0.02 & 0.382 & 0.386 & 0.704 & 0.834 \\
\hline & liranium & -- & 0.06 & $\mathrm{~N} / \mathrm{A}$ & NA & $N / A$ & $\mathrm{~N} / \mathrm{A}$ \\
\hline \multirow[t]{2}{*}{ Fecal } & : & 960 & 0.8 & 0.385 & $0.39]$ & 0.744 & 0.757 \\
\hline & ${ }^{23.6} \mathrm{Pu} /{ }^{2-349} \mathrm{Pu}$ & 960 & 0.2 & 0.385 & 0.391 & 0.90 & 0.85 \\
\hline
\end{tabular}

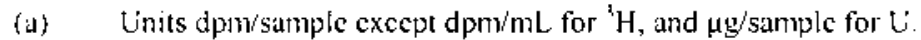

Outliers werc cxcluded from the test, but not ignored for the procedure evaluation. As stipulated in the Statement of Work, the mean relative bias shall lall within $\pm 20 \%$ when calculated from 15 to 50 spiked samples, and within $\pm 10 \%$ when calculatcd from over 50 samples.

\section{PRECISION}

The precision statistic used for this contract was $S_{13}$ from HPS N13.30 (1996), but the limits differ from that standard. $S_{B}$ is given by:

$$
S_{B}=\sqrt{\sum_{i=1}^{m} \sum_{i=1}^{\prime \prime} \frac{\left(B_{i_{1}}-B_{i}\right)^{2}}{(N-l)}}
$$

where the symbols are the same as for relative bias $\left(\mathrm{B}_{1}\right)$.

The above equation is valid for samples spiked at one or more levels, subject to the limits for the relative precision, which depend on the activity of the spikes relative to the $\mathrm{CL}$.

Specifically, the relative precision statistics shall be less than or equal to 0.4 for samples spiked greater than three times the CL and less than or equal to 0.5 for samples spiked between one and three times the C.L. Outliers were not included in the determination of precision. 


\section{FINDINGS}

Results from three types of QC samples were available: 1) those prepared by GEL and anaiyzed as single-blinds (spike amount unknown to the analyst), 2) those submitted by IDP and analyzed as single-blinds (spike amount unknown to the analyst), and 3) those submitted by IDP and analyzed as double-blinds (spike amount and sample origin unknown to the analyst).

Single-blind samples this year included 22 urines and 7 artificial fecal samples prepared by RPG. The results of the statistical tests (see Table 4 and Appendix A) are discussed below. Statistical results from the present and previous years are compared in Table 5.

\section{$\underline{\text { OUTLLIERS }}$}

Analytical results that are biased by "blunders" during the analysis should not be included in the data set used for the statistical evaluation of the analytical procedure, but too many outliers would indicate poor laboratory performance (see Table 6). GEL (see Appendix B) did not identify any outliers. However, there were 14 analytical ${ }^{241}$ An urinalysis results spiked at the CL that were determined to be outliers. These samples indicated activity between three to five times the CL. An investigation concluded that the samples were contaminated in the RPG laboratory during spiking. All 14 urine samples were spiked witl $0.02 \mathrm{dpm}{ }^{239} \mathrm{Pu}$ and $0.02 \mathrm{dpm}{ }^{241} \mathrm{Am}$, unfortunately the ${ }^{239} \mathrm{Pu}$ source material was contaminated with ${ }^{241} \mathrm{Am}$. The 14 data points were subsequently removed from the data set. 
TABLE 4. Summary of Statistical Values by Nuclide

\begin{tabular}{|c|c|c|c|c|c|c|c|c|c|c|c|}
\hline \multirow[b]{2}{*}{1 solope $\mathrm{e}^{(.1)}$} & \multirow{2}{*}{$\begin{array}{l}\text { Sample } \\
\text { Source }\end{array}$} & \multicolumn{3}{|c|}{ Blank (dpm) } & \multirow[b]{2}{*}{ CI } & \multicolumn{3}{|c|}{ Spike level at $\mathrm{CL}(\mathrm{d} p \mathrm{~m})$} & \multicolumn{3}{|c|}{ Spike Level $>2 C L(\mathrm{dpm})$} \\
\hline & & $\underline{\mathrm{n}}$ & $\underline{L_{\underline{L}}}$ & $\underline{\mathrm{MDA}}$ & & n & $\underline{B}_{r}$ & $\underline{S}_{B}$ & $\underline{11}$ & $\underline{B}_{1}$ & $\underline{S}_{13}$ \\
\hline${ }^{3} \mathrm{H}(\mathrm{dpm} / \mathrm{mL})$ & IDP & 0 & $\ldots$ & $\ldots$ & 20 & 0 & & & 0.00 & $\ldots$ & $\ldots$ \\
\hline \multirow{3}{*}{ Toral Sr } & GLL & 141 & 0.9960 & 0.009 & 20 & & & & 141 & -0.01 & 0.07 \\
\hline & IDP & 0 & $\ldots$ & $\ldots$ & 10 & 20 & 0.003 & 0.10 & 0 & $\ldots$ & $\ldots$ \\
\hline & GEI. & 20 & 0.32 & 2.82 & 10 & $\begin{array}{l}20 \\
12\end{array}$ & 0.05 & 0.13 & 20 & $-0,0)]$ & 0.06 \\
\hline " $\mathrm{Sr}$ & Gil. & 127 & 0.62 & 2.32 & 10 & 3 & -0.02 & 0.15 & 133 & 0.015 & 0.103 \\
\hline${ }^{12 . "} \mathrm{Th}$ & GEL & 6 & 0.030 & 0.044 & 0.1 & $\ldots$ & $\cdots$ & $\ldots$ & $\ldots$ & $\ldots$ & $\ldots$ \\
\hline$\because n+1 \mathrm{~h}$ & GLL & 6 & 0.021 & 0.032 & 0.1 & $\ldots$ & $\ldots$ & $\ldots$ & $\ldots$ & $\ldots$ & $\ldots$ \\
\hline$\cdots \cdot T h$ & Gili. & 6 & 0.021 & 0.032 & 0.1 & 1 & 0.05 & $\ldots$ & 1 & -0.042 & $\ldots$ \\
\hline $13 \mathrm{rh}$ & GFI. & 6 & 0.021 & 0.036 & 0.1 & $\ldots$ & $\ldots$ & $\ldots$ & $\ldots$ & $\ldots$ & $\ldots$ \\
\hline "l'cm & Gili. & 38 & 0.004 & 0.011 & 0.02 & $\ldots$ & $\ldots$ & $\cdots$ & $\ldots$ & $\ldots$ & $\ldots$ \\
\hline${ }^{-t+} \mathrm{Com}$ & GEL & 155 & 0.004 & 0.010 & 0.02 & 30 & 0.19 & 0.28 & 38 & 0.065 & 0.095 \\
\hline \multirow[t]{2}{*}{${ }^{2: 3 x} P_{u-\text {-urine }}$} & IDP & 32 & $0.0\} 1$ & $0.025^{(c)}$ & 0.02 & 0 & $\ldots$ & $\ldots$ & 0 & $\ldots$ & $\ldots$ \\
\hline & GEL & 426 & 0.004 & 0.010 & 0.02 & $\ldots$ & $\ldots$ & $\ldots$ & $\ldots$ & $\ldots$ & $\ldots$ \\
\hline \multirow[t]{2}{*}{ feces } & IDP & 7 & 0.01 & 0.041 & 0.2 & 0 & $\cdots$ & $\cdots$ & 0 & $\cdots$ & $\cdots$ \\
\hline & GEL & 34 & 0.01 & 0.069 & 0.2 & $\ldots$ & $\ldots$ & $\ldots$ & $\ldots$ & $\ldots$ & $\ldots$ \\
\hline \multirow[t]{2}{*}{${ }^{2: 11}$ Pu-urine } & IDP & & & & 0.02 & $\begin{array}{l}33 \\
37\end{array}$ & -0.02 & 0.30 & 0 & $\ldots$ & $\ldots$ \\
\hline & GEL & 426 & 0.005 & $0.01 !$ & 0.02 & 8 & 0.02 & 0.27 & 454 & -0.001 & 0.072 \\
\hline \multirow{2}{*}{ feces } & IDP & 2 & 0.04 & 0.197 & 0.2 & 5 & -0.10 & 0.11 & 0 & & \\
\hline & GEL & 34 & 0.01 & 0.076 & 0.2 & 31 & 0.17 & 0.00 & 25 & -0.055 & 0.057 \\
\hline \multirow[t]{2}{*}{${ }^{2+1}$ Am-urine } & IDP & & & & 0.02 & $\begin{array}{l}25 \\
14\end{array}$ & 0.14 & 0.50 & 0 & $\ldots$ & $\ldots$ \\
\hline & GEl. & 155 & 0.004 & 0.011 & 0.02 & 6 & $0.012^{(\mathfrak{c})}$ & 0.32 & 157 & 0.053 & 0.107 \\
\hline \multirow[t]{2}{*}{ feces } & IDP & 2 & 0.03 & 0.205 & 0.8 & 5 & -0.08 & 0.10 & 0 & $\ldots$ & $\ldots$ \\
\hline & GELL & 24 & 0.01 & 0.062 & 0.8 & 21 & 0.11 & 0.20 & 19 & 0.005 & $0.08^{\circ}$ \\
\hline \multirow[t]{2}{*}{${ }^{24}$ Am-uritle } & IDP & 7 & 0.006 & 0.016 & 0.02 & 0 & $\ldots$ & $\ldots$ & 0 & $\ldots$ & $\ldots$ \\
\hline & GEL & 38 & 0.005 & 0.013 & 0.02 & 17 & 0.20 & 0.32 & 37 & -0.013 & 0.097 \\
\hline \multirow[t]{2}{*}{$\stackrel{i+1}{U}$} & IDP & 0 & ... & $\ldots$ & 0.02 & $\ldots$ & $\ldots$ & $\ldots$ & 0 & $\ldots$ & $\ldots$ \\
\hline & GFl. & 80 & 0.010 & $0.021^{\text {ie\} }}$ & 0.02 & $\ldots$ & $\ldots$ & $\ldots$ & $\ldots$ & $\ldots$ & $\ldots$ \\
\hline lices & GEL & 2 & 0.149 & 0.016 & $\cdots$ & $\ldots$ & $\cdots$ & $\ldots$ & $\ldots$ & $\cdots$ & $\ldots$ \\
\hline \multirow[t]{2}{*}{$\because 5 \mathrm{y}$} & IDP & 8 & $\ldots$ & 0.020 & 0.02 & $\ldots$ & $\ldots$ & $\ldots$ & 0 & $\ldots$ & $\ldots$ \\
\hline & GEL. & 80 & 0.007 & 0.016 & 0.02 & $\ldots$ & $\ldots$ & $\ldots$ & $\ldots$ & $\ldots$ & $\ldots$ \\
\hline lices & GEL & 2 & 0.085 & 0.016 & $\ldots$ & $\ldots$ & $\ldots$ & $\cdots$ & $\ldots$ & $\cdots$ & $\cdots$ \\
\hline \multirow[t]{2}{*}{${ }^{1: 88} \mathrm{U}$} & IDP & 0 & $\ldots$ & $\ldots$ & 0.02 & 16 & -0.02 & 0.30 & 0 & & \\
\hline & GEL & 80 & 0.009 & 0.020 & 0.02 & 78 & -0.04 & 0.22 & 82 & -0.05 & 0.11 \\
\hline fices & GEL & 2 & 0.112 & 0.016 & $\ldots$ & 2 & $0.514^{(k)}$ & $0.536^{(1)}$ & 2.00 & 0.105 & 0.005 \\
\hline (ICPMS) & GE? & 1 & 0.000 & $95.5 \mathrm{pg}$ & $140 \mathrm{pg}$ & 1 & -0.05 & $\ldots$ & $\ldots$ & .. & $\ldots$ \\
\hline \multirow[t]{2}{*}{$e^{-}$-urine $e^{(b)}$} & IDP & 0 & $\begin{array}{c}\ldots \\
0.006\end{array}$ & $\ldots$ & 0.06 & 0 & & & 22 & -0.064 & 0.321 \\
\hline & GEI & 225 & $\mu \mathrm{g}$ & $0.011 \mu g$ & $0.06 \mu \mathrm{g}$ & 74 & -0.12 & 0.20 & 75 & -0.124 & 0.117 \\
\hline
\end{tabular}

(a) Anilyzed in urine matrix unless otherwise noted.

(b) Units for $L_{b}, M D A$, and $C L$ are mg per sample.

(c) Falled performance eritcrion. (d) Possible environmental contaminant.

(c) Within statistical uncertainty

(i) Stats for Com same as $A m-241$ 
TABLE 5. Comparison of Quality Control Statistics Between the First and Second Contract Year with GEL Using QC Samples Submitted by IDP

\begin{tabular}{|c|c|c|c|c|c|c|c|c|c|c|c|}
\hline \multirow[b]{2}{*}{ Nislude } & \multirow[b]{2}{*}{$\mathrm{Cl}$} & \multicolumn{2}{|l|}{ Report } & \multicolumn{2}{|c|}{ Blanks } & \multicolumn{3}{|c|}{ Spike Lcvel at CL } & \multicolumn{3}{|c|}{ Spike Level > $3 \mathrm{CL}$} \\
\hline & & Ycar & $n$ & $L_{i}$ & MDA & $n$ & $B_{\mathrm{r}}$ & $S_{i s}$ & $n$ & $\mathrm{~B}_{1}$ & $S_{1 k}$ \\
\hline \multirow[t]{2}{*}{31} & $20 \mathrm{dpm} / \mathrm{mL}$ & 2006 & 1 & $\ldots$ & $\ldots$ & 2 & 0.42 & 0.6 .3 & $\ldots$ & $\ldots$ & $\ldots$ \\
\hline & & 2007 & 0 & $\cdots$ & $\ldots$ & 0 & 0.00 & 0.00 & $\cdots$ & $\ldots$ & $\ldots$ \\
\hline \multirow[t]{2}{*}{$\mathrm{Sr}$} & $10 \mathrm{dpm}$ & 2006 & 1 & $\ldots$ & $\ldots$ & 14 & 0.12 & 0.23 & $\ldots$ & $\ldots$ & $\ldots$ \\
\hline & & 2007 & 0 & $\ldots$ & $\ldots$ & 20 & 0.00 & 0.10 & 0 & $\ldots$ & $\ldots$ \\
\hline $\mathrm{U}$ & $0.06 \mathrm{~m}$ ngy & 2006 & 1 & $\ldots$ & $\ldots$ & 2 & $-1.6(c)$ & $2.05(\mathrm{c})$ & 15 & -0.14 & 0.22 \\
\hline \multicolumn{2}{|c|}{ (slemental) } & 2007 & 0 & $\ldots$ & $\ldots$ & 0 & 0.00 & 0.00 & 22 & -0.06 & 0.32 \\
\hline \multirow[t]{2}{*}{$2 n \mathrm{U}$} & $0.02 \mathrm{dpm}$ & 2006 & 12 & 0.01 & 0.02 & $\therefore$ & $-0.24(c)$ & 0.3 & $\ldots$ & $\ldots$ & $\ldots$ \\
\hline & & 2007 & 8 & $\ldots$ & 0.02 & .. & $\cdots$ & $\cdots$ & 0 & $\cdots$ & $\ldots$ \\
\hline \multirow[t]{2}{*}{${ }^{2138} \mathrm{U}$} & $0.02 \mathrm{dpm}$ & 2006 & $\ldots$ & $\ldots$ & $\ldots$ & 0 & 0.00 & 0.00 & 15 & 0.02 & 0.23 \\
\hline & & 2007 & 0 & $\ldots$ & $\ldots$ & 16 & -0.02 & 0.30 & 0 & 0.00 & 0.00 \\
\hline \multirow{2}{*}{$\begin{array}{l}{ }^{2 s x_{P_{t !}}} \\
\text { (turine) }\end{array}$} & $0.02 \mathrm{dpm}$ & 2006 & 21 & 0.004 & 0.011 & 1 & -0.18 & $\ldots$ & $\ldots$ & $\ldots$ & $\ldots$ \\
\hline & & 2007 & 32 & 0.011 & $0.025(\mathrm{e})$ & 0 & $\ldots$ & $\ldots$ & 0 & $\ldots$ & \\
\hline \multirow{2}{*}{$\begin{array}{l}{ }^{3.9} \mathrm{Pu} \\
\text { (turine) }\end{array}$} & $0.02 \mathrm{dpm}$ & 2006 & 6 & 0.002 & 0.009 & 16 & 0.05 & 0.2 .3 & $\cdots$ & $\ldots$ & $\ldots$ \\
\hline & & 2007 & 0 & 0.000 & 0.000 & 33 & -0.02 & 0.30 & 0 & $\cdots$ & $\ldots$ \\
\hline \multirow{2}{*}{$\begin{array}{l}{ }^{: 34} \mathrm{Pu} \\
\text { (fecal) }\end{array}$} & $0.2 \mathrm{dpm}$ & 2006 & 6 & 0.027 & 0.07 & $\ldots$ & $\ldots$ & $\ldots$ & 6 & -0.05 & 0.09 \\
\hline & & 2007 & 2 & 0.036 & 0.20 & 5 & 0 & 0 & 0 & 0.00 & 0.00 \\
\hline \multirow{2}{*}{$\begin{array}{l}{ }^{2+1} \wedge \mathrm{m} \\
\text { (urine) }\end{array}$} & $0.02 \mathrm{~d}$ & 2006 & 2 & 0.005 & 0.068 (c) & 17 & 0.19 & 0.35 & $\cdots$ & $\ldots$ & $\ldots$ \\
\hline & & 2007 & 0 & 0.000 & 0.000 & 25 & 0.14 & 0.50 & 0 & $\cdots$ & $\ldots$ \\
\hline \multirow{2}{*}{$\begin{array}{l}:{ }^{-\lambda} \mathrm{Am} \\
\text { (lecal) }\end{array}$} & $0.02 \mathrm{dpm}$ & 2006 & 8 & 0.025 & 0.063 & 4 & -0.17 & 0.09 & $\ldots$ & $\ldots$ & $\ldots$ \\
\hline & & 2007 & 2 & 0.033 & 0.205 & 5 & -0.08 & 0.10 & 0 & $\ldots$ & $\cdots$ \\
\hline \multirow[t]{2}{*}{${ }^{213} \mathrm{Am}$} & $0.02 \mathrm{dpm}$ & 2006 & 2 & 0.020 & 0.09 & 0 & $\cdots$ & $\ldots$ & $\ldots$ & $\ldots$ & $\ldots$ \\
\hline & & 2007 & 7 & 0.006 & 0.016 & 0 & $\ldots$ & $\ldots$ & 0 & $\ldots$ & $\ldots$ \\
\hline
\end{tabular}

Note: $L_{-}$and MDA units same as $C L . B_{r}$ and $S_{R}$ are unitless (fractional values). 
TABLE 6. Other Indicators of Analytical Uncertainty (IDP Samples)

Spikes at

$\mathrm{CDL}$
False

Negatives $(\%) \quad$ Yield Failed

\begin{tabular}{|c|c|c|c|c|c|c|c|c|}
\hline Nuclide & Analyses & Outliers & IDP & GEL & IDP & GEL & Flags & Analyses \\
\hline \multicolumn{9}{|l|}{ Urine } \\
\hline${ }^{3} \mathrm{H}$ & 0 & $0(0)$ & 0 & & $0(0)$ & & & \\
\hline${ }^{90} \mathrm{Sr}$ & 20 & $0(0)$ & 20 & 20 & $0(0)$ & & $1.4 \%$ & $0.2 \%$ \\
\hline${ }^{23 *} \mathrm{U}$ & 16 & $0(0)$ & 16 & 78 & $0(0)$ & & $13.5 \%$ & $2.9 \%$ \\
\hline${ }^{238} \mathrm{Pu}$ & 32 & $0(0)$ & 0 & & $0(0)$ & & $0.4 \%$ & $0.0 \%$ \\
\hline${ }^{234} \mathrm{Pu}$ & 33 & $0(0)$ & 33 & 378 & $\begin{array}{c}1 \\
(3 \%)\end{array}$ & $4(1 \%)$ & $0.4^{\% / 1}$ & $0.0 \%$ \\
\hline${ }^{2+1} \mathrm{Am}$ & 11 & $14(56 \%)$ & 11 & 146 & $0(0)$ & $1(0.7 \%)$ & $0.4 \%$ & $0.4 \%$ \\
\hline${ }^{2+3} \mathrm{Am}$ & 7 & $0(0)$ & 0 & 17 & $0(0)$ & & & \\
\hline Unat & 22 & $0(0)$ & 22 & 74 & $0(0)$ & & $1.3 \%$ & $1.3 \%$ \\
\hline Total & 149 & $0(0)$ & 68 & & $0(0)$ & & & \\
\hline \multicolumn{9}{|l|}{ Feces } \\
\hline${ }^{241} \mathrm{Am}$ & 7 & $0(0)$ & 5 & 21 & $0(0)$ & & $25.0 \%$ & $4.2 \%$ \\
\hline${ }^{238} \mathrm{Pu}$ & 7 & $0(0)$ & $\ldots$ & & $0(0)$ & & $6.3 \%$ & \\
\hline${ }^{239} \mathrm{Pul}$ & 7 & $0(0)$ & 5 & 31 & $0(0)$ & & & \\
\hline Total & 21 & $0(0)$ & 10 & & $\theta(0)$ & & & \\
\hline
\end{tabular}

\section{TRITIUM}

Effective June 2006, the tritium intercomparison program by IDP was discontinued, performance indicators will be evaluated through GEL's QC program. The control samples run by GEL also met all the acceptance criteria tested as part of the quality control program. The tritium analyses were considered acceptable.

\section{STRONTIUM-90 AND TOTAL STRONTIUM}

The total strontium procedure is used to screen samples to determine which will require analysis for ${ }^{10} \mathrm{Sr}$. Samples with total strontium results less than $15 \mathrm{dpm}$ do not undergo further analysis. Samples with results greater than or equal to $15 \mathrm{dpm}$ may undergo ${ }^{90} \mathrm{Y}$ in growth to specifically determine ${ }^{(1)} \mathrm{Sr}$ levels. The calculated MDA, as reported by GEL, for the total strontium part of the analysis was about $28 \%$ of the CL. The relative bias and precision, tested by IDP and GEL for the ${ }^{90} \mathrm{Sr}$ and total $\mathrm{Sr}$ procedures were all within limits. The 20 samples spiked at the contractual level by IDP were all detected. The strontium urinalysis procedure was concluded to be acceptable. 


\section{PLUTONIUM-238 AND --239}

Samples spiked with ${ }^{238} \mathrm{Pu}$ and ${ }^{239} \mathrm{Pu}$ were analyzed using the same procedures and same reagents. The two isotopes are differentiated only at the end of the procedure by alpha spectrometry. Therefore, laboratory performance is expected to be similar for both isotopes using any of the seven procedures that incorporate plutonium analysis (IPU, IPA, IPS, IPSA, IPSR, IUPU, and ITPAC).

The MDAs and pcrformance statistics for ${ }^{239} \mathrm{Pu}$ and ${ }^{238} \mathrm{Pu}$ in urine were acceptable. The 33 samples spiked at the CL for ${ }^{239} \mathrm{Pu}$ were reported witl only onc result less than the decision level indicating a $3 \%$ false negative. There were four blank samples indicaling ${ }^{238} \mathrm{Pu}$ activity, one sample indicated activity in excess of the CL. Upon revicw it appears that the samples may have been crosscontaminated during handling in the audit laboratory. Results of the four samples were not removed from the data set bccause it could not be verified that the samples were contaminated. Including the four elevated samples, the MDA as analyzed by IDP for ${ }^{23 x} \mathrm{Pu}$ was only slightly clcvated. GEL reported an MDA for ${ }^{238} \mathrm{Pu}$ that was $50 \%$ of the CL. Overall the plutonium urinalyses were considered acceptable.

\section{URANIUM (UNAT)}

No concerns were identified with the elemental uranium urinalysis program and it was considered acceptable. Because IDP uses a $0.2 \mu \mathrm{g}$ screening level for elemental uranium, samples spiked at $0.06 \mu \mathrm{g}$ were discontinued. The MDA at the contractual level of $0.06 \mu \mathrm{g}$ was evaluated through GEL's program and were found to be acceptable. The relative bias was within statistical uncertainty and the relative precision was acceptable. The bias and precision as tested by IDP met the acceptance criteria. The bias and precision was tested by IDP at $0.2 \mu \mathrm{g}$ and by GEL at $1 \mu \mathrm{g}$ and at $0.06 \mu \mathrm{g}$.

\section{$\underline{\text { ISOTOPIC URANIUM }}$}

The isotopic uranium analysis reports on three uranium isotopes: ${ }^{234} \mathrm{U},{ }^{235} \mathrm{U}$, and ${ }^{238} \mathrm{U}$. The isotopes are differentiated only during counting by alpha spectrometry. GEL reported that the calculated minimum detectable activity (MDA) for ${ }^{233,234} \mathrm{U}$ for the year slightly exceeded the contract required detection limit. The MDA reported by GEL was within statistical uncertainty and determined to be acceptable.

Because IDP used a depleted uranium source material for the isotopic uranium urinalyses, ${ }^{233,234} \mathrm{U}$ was not evaluated. However, the performance statistics for ${ }^{235} \mathrm{U}$ and ${ }^{238} \mathrm{U}$ were reviewed and the MDA for ${ }^{235} \mathrm{U}$ and the bias and precision for ${ }^{23 x} \mathrm{U}$ werc acceplable. GEL is still working to improve the 
tracer yields on the isotopic uranium urinalysis program and this will continue to be monitored.

\section{AMERICIUM-241}

$T h e^{2+1} \wedge \mathrm{m}$ fecal and urine analysis met the acceptance criteria for MDA, relative bias and precision. The MDA as reported by GEL was $50 \%$ of the contractual level. There were $25{ }^{241} \mathrm{Am}$ samples spiked at the contractual detection level $(\mathrm{CL})$ and 14 indicated activity between three to five times the CL. An investigation, which ran from November 2007 through March 2008, concluded that the samples were contaminated in the RPG laboratory daring spiking (Attachment 1). All 14 urine samples were spiked with $0.02 \mathrm{dpm}{ }^{234} \mathrm{Pu}$ and $0.02 \mathrm{dpm}{ }^{241}$ Am, unfortunately the ${ }^{234} \mathrm{Pu}$ source material was contaminated with ${ }^{2+1} \mathrm{Am}$. Americium-24l may have been added to the ${ }^{236} \mathrm{Pu}$ source material via a contaminatcd pipette tip, however, the exact circumstance is unknown. A new ${ }^{239} \mathrm{Pu}$ source material wals prepared. Subsequent samples did not show ${ }^{241}$ Am contamination.

The 14 data points werc removed from the data set to evaluate the relative bias and precision, both of which met the acceptance criteria. GEL reported a slightly clevated precision for ${ }^{241} \mathrm{Am}$, but the results were within statistical uncertainty. The current AM241 urinalysis procedure was considered acceptable.

Both blank ${ }^{241}$ Am fecal samples were less than the decision level and the five spiked fecal samples were all greater than the decision. The ${ }^{241} \mathrm{Am}$ fecal duplicate samples were evaluated and it was concluded that the aliquoting procedure produced results within the control limits.

\section{AMERICIUM-243}

The AM243 procedure was identical to the AM241 procedure, excepl a different tracer is used $\left({ }^{244} \mathrm{Cm}\right.$ instead of $\left.{ }^{243} \mathrm{Am}\right)$. The seven blank ${ }^{243} \mathrm{Am}$ QC satmples submitted were all reported with results less than the decision level and the calculated MDA was $65 \%$ of the contractual detection level. The performance statistics for ${ }^{243} \mathrm{Am}$, as tested by GEL, met the acceptance criteria. The ${ }^{243}$ Am procedure was concluded to be acceptable.

\section{ISOTOPIC CURIUM}

IDP did not submit QC samples to test the isotopic curium program, therefore performance statistics were based on the GEL QC results. GEL tested the MDA for ${ }^{242} \mathrm{Cm}$ and ${ }^{244} \mathrm{Cm}$ and the relative bias and precision for ${ }^{244} \mathrm{Cm}$. The results met the acceptance criteria and the isotopic curium urinalysis program was considered acceptable. 


\section{ISOTOPIC THORIUM}

IDP also did not submit QC samples to test the isolopic thorium program, therefore performance statistics were based on the GEL QC results. GEL tested the MDA for ${ }^{228} \mathrm{Th},{ }^{229} \mathrm{Th},{ }^{230} \mathrm{Th}$ and ${ }^{232} \mathrm{Th}$ and the relative bias and precision for ${ }^{232} \mathrm{Th}$. The results met the acceptance criteria and the isotopic thorium urinalysis program was considered acceptable.

\section{URANIUM VIA INDUCTIVELY COUPLED PLASMA MASS SPECTROMETRY (ICPMS)}

A new ${ }^{236} \mathrm{U}$ analysis procedure was initiated in June 2007 and one urinalysis was run. The analysis for ${ }^{236} \mathrm{U}$ uses an inductively coupled plasma mass spectrometry (ICPMS). A review of the ${ }^{236} \mathrm{U}$ analysis determined that more work was needed in relucing uncertainties and improving the analysis. The procedure was not formally approved until June 2008 and will be discussed in the fourth contract year's report.

\section{FOLLOW-UP ON CONCERNS DURING THE THIRD CONTRACT YEAR}

There were few concerns during the third year with General Engineering Laboratories (GEL). The main emphasis was developing an ICPMS procedure for ${ }^{236} \mathrm{U}$ analysis. This was accomplished in June 2008.

A review of Incident reports since the contract wilh GEL was initiated did not identify a trend or a concern. The majority of incident reports were due to human error and corrective actions were decmed acceptable. Incident reports issued during the second contract year and their follow-up are reported in Appendix B. 


\section{INCORPORATED, FOR THE CONTRACT 313500 FOURTH OPERATIONAL YEAR}

GEL reported all analytical batches were analyzed with a reagent blank (Unat only), matrix blank or both. GEL considered blanks in control when the calculate MDA was less than the Contract Limit (CL) and the $L_{\mathfrak{L}}$ was less than $1 / 2 \mathrm{CL}$ (see Appendix B). In addition, the chemical tracer yields were evaluated against the yicld requirements stated in the subject contract. Overall, GEL believed that the blank and spike data for each analytical process demonstrated that the anaiyses were in control.

In the review GEL indentified laboratory control samples that had yields greater than $125 \%$. However, a review of excreta sample results found no analytical sample that had a tracer yield greater than $125 \%$. GEL also indentified laboratory control samples that met the criteria for low yield, but likcwise a revicw of excreta sample results found the low yield rate to be acceptable. GEL is stil] working to improve the tracer yields on the isotopic uranium urinalysis program and this will continue to be monitored.

\section{RESULTS FROM INTERCOMPARISON PROGRAMS}

GEL participated in 3 intercomparison programs (Appendix D - Intercomparison Programs) in the third contract year. On April 1, 2006 they participated in the National Institute of Standards and Technology's program testing the relative bias and precision for ${ }^{238} \mathrm{Pu},{ }^{239} \mathrm{Pu},{ }^{241} \mathrm{Am},{ }^{2307 \mathrm{th}},{ }^{235} \mathrm{U},{ }^{23 *} \mathrm{U}$, ${ }^{234} \mathrm{U}$ and ${ }^{10} \mathrm{Sr}$ in synthetic feces. GEL met the acceptance critcria for relative bias and precision for all isolopes except for ${ }^{\%} \mathrm{Sr}$, which failed the portion on relative bias but passed on relative precision. Because Hanford does not use fecal samples for strontium analyses, this was not deemed a concern. GEL also participated in the National Institute of Standards and Technology's program testing the relative bias and precision for ${ }^{238} \mathrm{Pu},{ }^{239} \mathrm{Pu},{ }^{241} \mathrm{Am},{ }^{230} \mathrm{Th},{ }^{235} \mathrm{U},{ }^{238} \mathrm{U},{ }^{234} \mathrm{U},{ }^{90} \mathrm{Sr},{ }^{60} \mathrm{Co},{ }^{133} \mathrm{Ba},{ }^{137} \mathrm{Cs}$ and ${ }^{1.52} \mathrm{Eu}$ in synthetic urine. GEL met the acceptance critcria for relative bias and precision on all isotopes.

On December 1, 2006 GEL participated in the Department of Energy Laboratory Accreditation Program, Session 10. Isotopes tested in a fecal matrix were ${ }^{238} \mathrm{Pu},{ }^{239} \mathrm{Pul},{ }^{241} \mathrm{Am},{ }^{230} \mathrm{Th},{ }^{232} \mathrm{Th},{ }^{2228} \mathrm{Th}$ ${ }^{238} \mathrm{U},{ }^{234} \mathrm{U},{ }^{96} \mathrm{Sr},{ }^{60} \mathrm{Co}$, and ${ }^{137} \mathrm{Cs}$. sotopes tested in a urine matrix were ${ }^{238} \mathrm{Pu},{ }^{234} \mathrm{Pu},{ }^{241} \mathrm{Am},{ }^{230} \mathrm{Th},{ }^{232} \mathrm{Th}$, ${ }^{222 \mathrm{~K}} \mathrm{Th},{ }^{238} \mathrm{U},{ }^{234} \mathrm{U},{ }^{90} \mathrm{Sr},{ }^{60} \mathrm{Co},{ }^{137} \mathrm{Cs}$, tritium and U-tolal. GEL passed the acceptance criteria for all isotopes in both the fecal and urine matrix for relative bias and precision. 


\section{REFERENCES}

American Society for Testing and Materials (ASTM). 1994. Standard Practice for Dealing with Outlying Observations. ASTM E 178-94, ASTM, Philadelphia, Pennsylvania.

Health Physics Society (HPS). 1996. Health Physics Society Standard for Performance Criteria for Radiobioassay. HPS N13.30-1996, HPS, McLean, VA.

Battelle. 2007. "Contract No. 11530 Mod 5 Bioassay Radiochemical Analytical Services" General Engineering Laboratories, LLC, Charleston, South Carolina. (Available from the Hanford Radiological Records Historical File.)

Currie, L. A. 1968. "Limits for Qualitative Detection and Quantitative Determination." Analytical Chemistry 40(3):586-593.

Remmington, Richard D. and M. Anthony Schork, 1970. Statistics with Applications to the Biological and Health Sciences. Printice-Hall. New York.

Pifer, S. 2007. "PNNL Annual QC Package, Second Contract Year 2006/2007 (April 1, 2006 . March 31, 2007)" Letter Report, General Engineering Laboralories, LLC, Charleston, South Carolina. (Available from the Hanford Radiological Records Historical File.)

Pifer, S. 2008. " PNNL Annual QC Package, Second Contract Year 2007/2008 (April 1, 2007 - March 31, 2008)" Letter Report, General Engineering Laboratories, LLC, Charleston, South Carolina. (Available from the Hanford Radiological Records Historical File.)

Miller, Irwin and John Freund, 1977. Probability and Statistics for Engineers. Prentice-Hall. Englewood Cliffs, New Jersey. 


\section{RELEVANT PROCEDURES AND CORRESPONDENCE}

Antonio, C. L.. 2006. "Results of the PNL Excreta Bioassay Quality Control Oversight Program for April 1, 2006 through June 30, 2006." Letter Report, Pacific Northwest Laboratory, Richland, Washington. (Available from the Hanford Radiological Records Historical File.)

Antonio, C. L. 2007. "Results of the PNL Excreta Bioassay Quality Control Oversight Program for July 1, 2006 through September 30, 2006." Letter Report, Pacific Northwest Laboratory, Richland, Washington. (Available from the Hanford Radiological Records Historical Filc.)

Antonio, C. L. 2007. "Results of the PNL Excreta Bioissay Quality Control Oversight Program for October 1, 2006 through December 31, 2006." Letter Report, Pacific Northwest Laboratory, Richland, Washington. (Available from the Hanford Radiological Records Historical Filc.) 
APPENDIX A

QUALITY CONTROL SAMPLE RESULTS

(Historical File Only) 


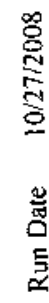

䒺

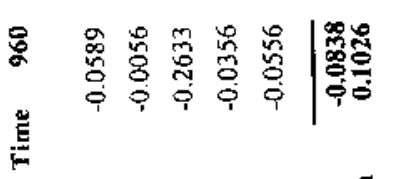

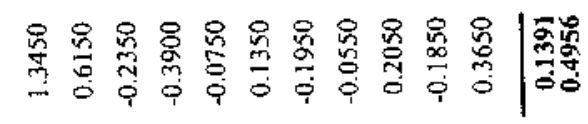

$\stackrel{\infty}{\infty}$

产
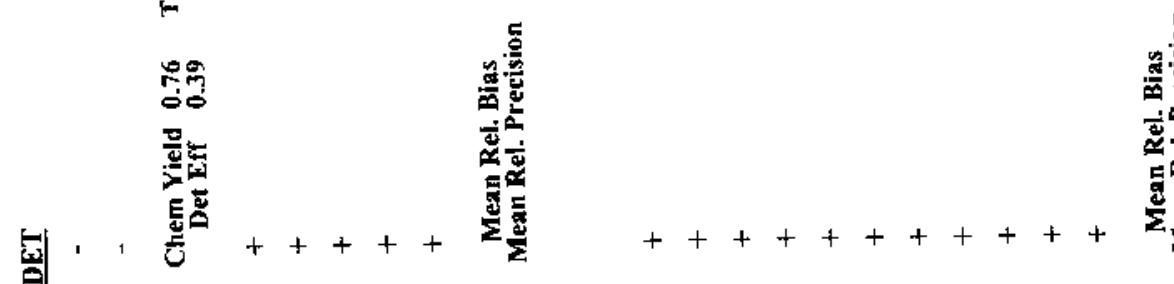

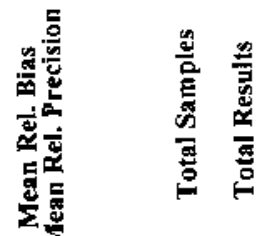

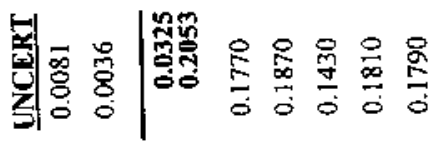

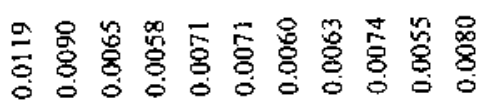

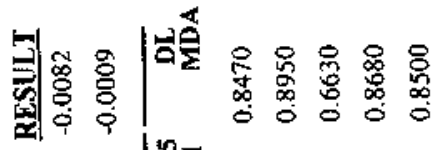

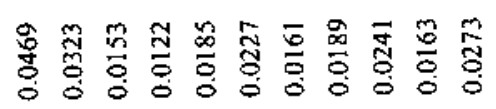

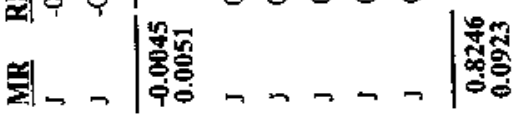

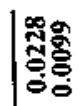

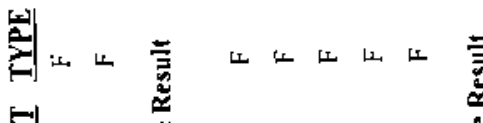

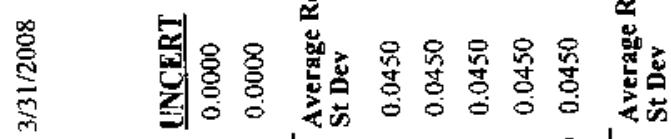

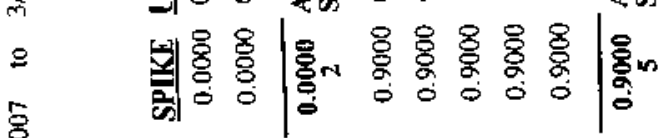

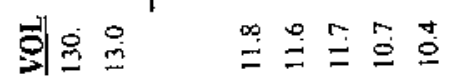

$\supset D D D P D D D D D \bar{~}$

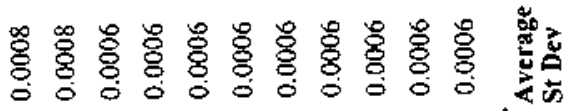

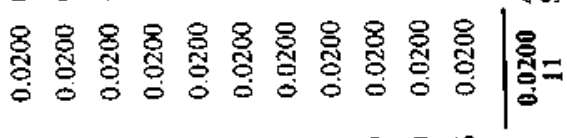

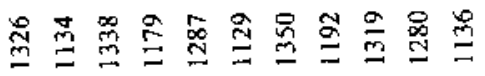

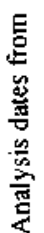

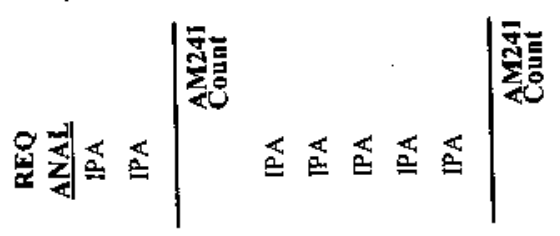

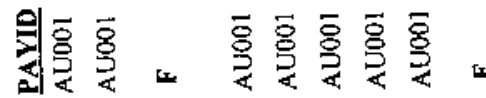

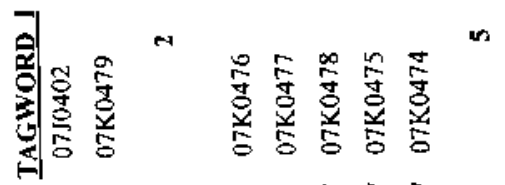

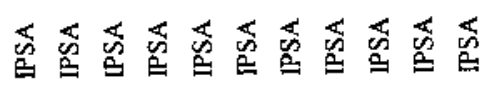

추를

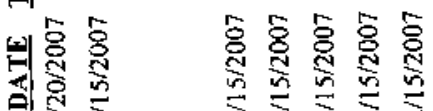

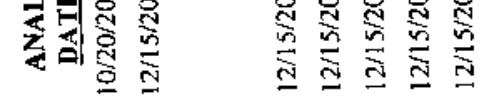



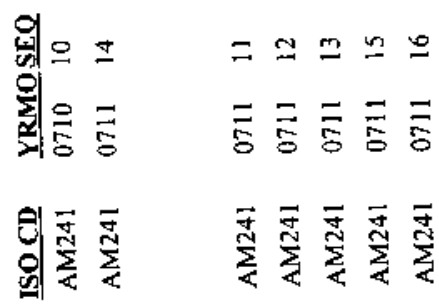

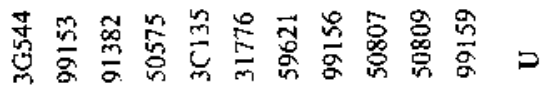

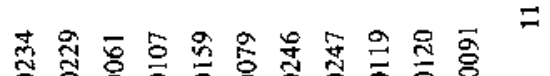

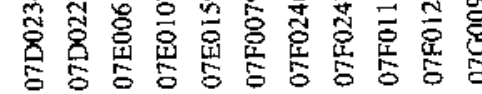

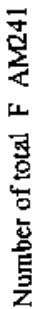

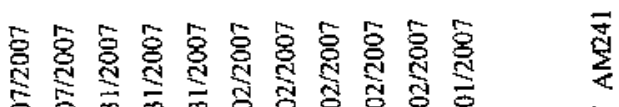

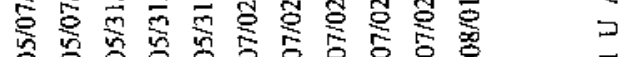

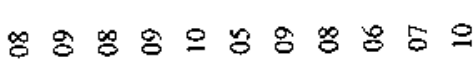

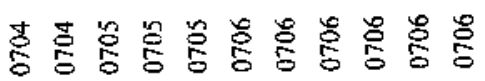

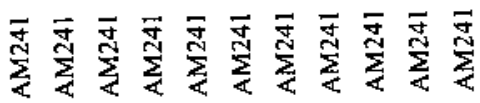


苂

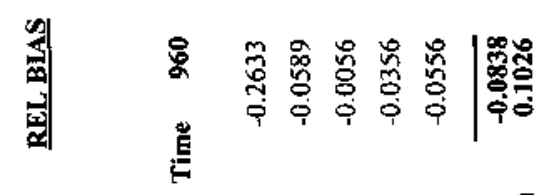

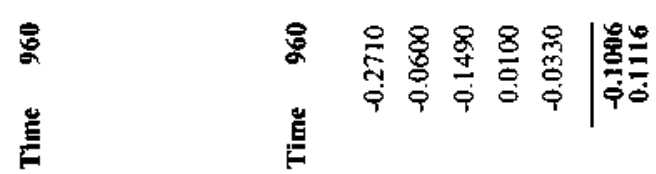

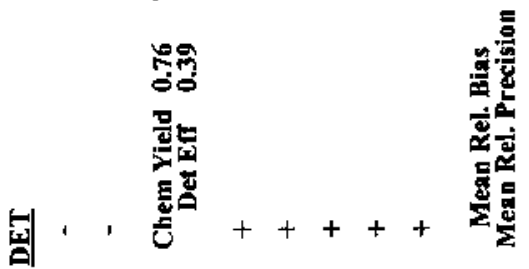

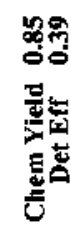

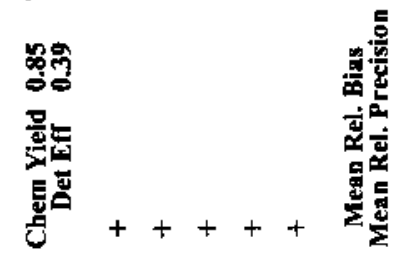

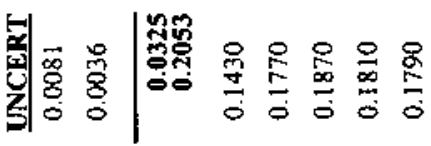

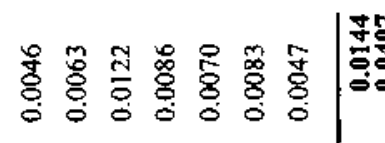

芦命

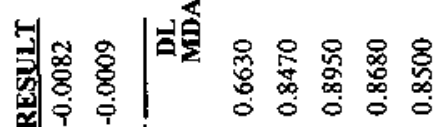

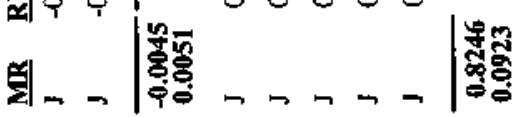

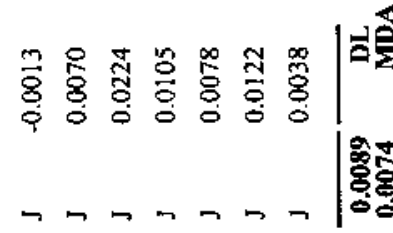

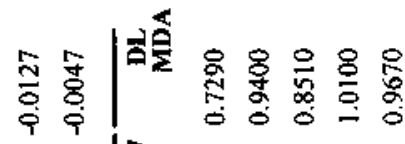

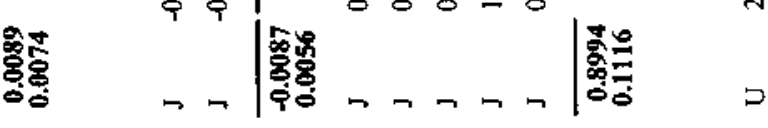

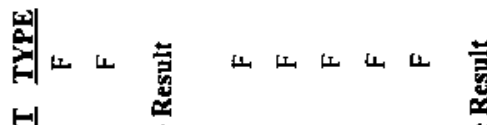

山地士上山上击

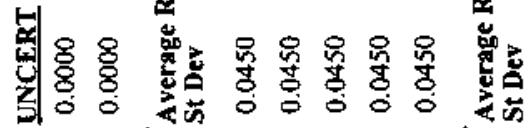

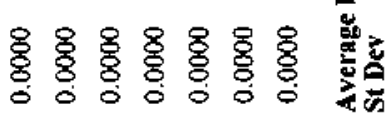

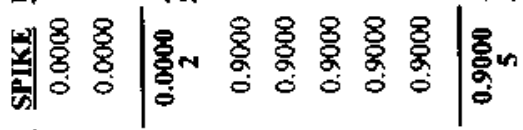

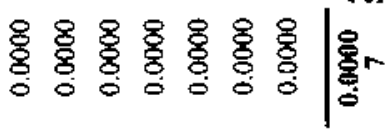

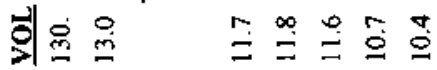

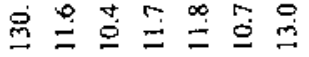

is is

\&

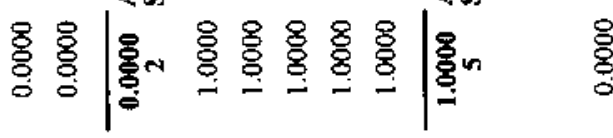

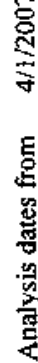

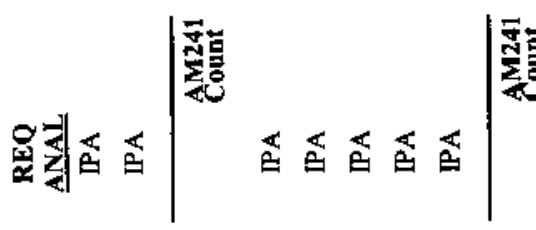

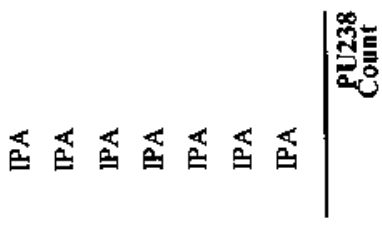

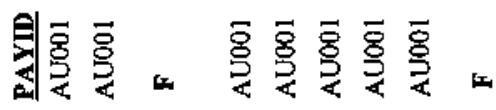

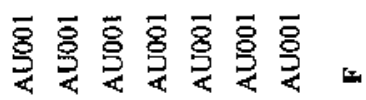

คำำ

$\stackrel{\infty}{=} \stackrel{+}{\Xi} \stackrel{0}{=}$

品

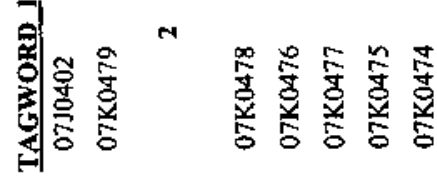

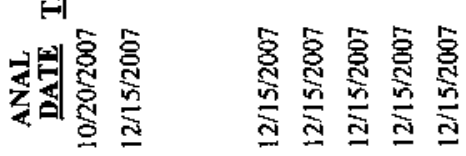

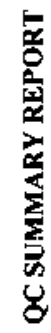

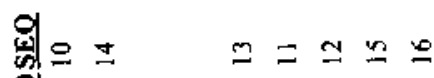

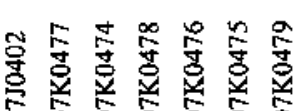

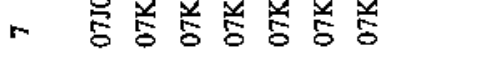

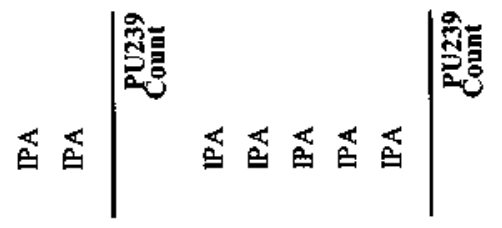

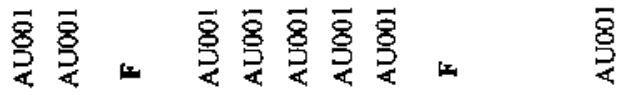

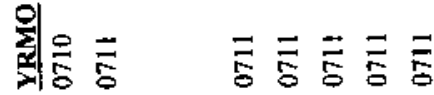

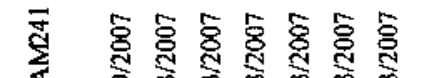

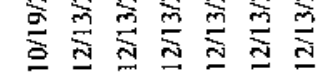

으믄

害莒

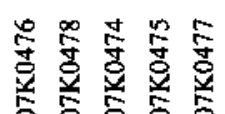

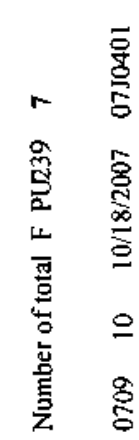

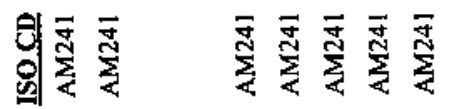

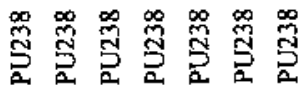

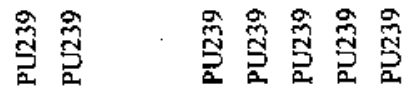

$\stackrel{\text { I }}{2}$ 


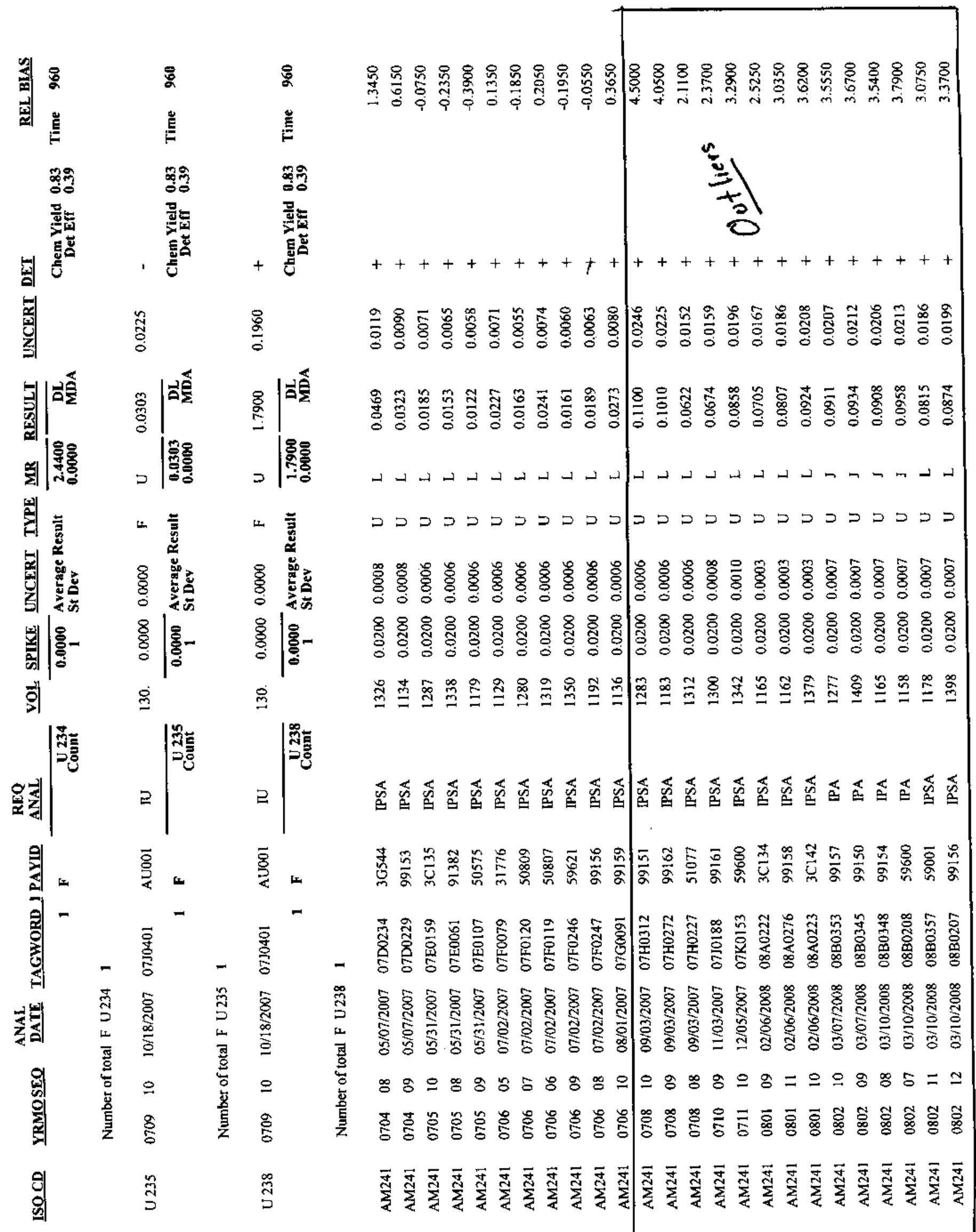




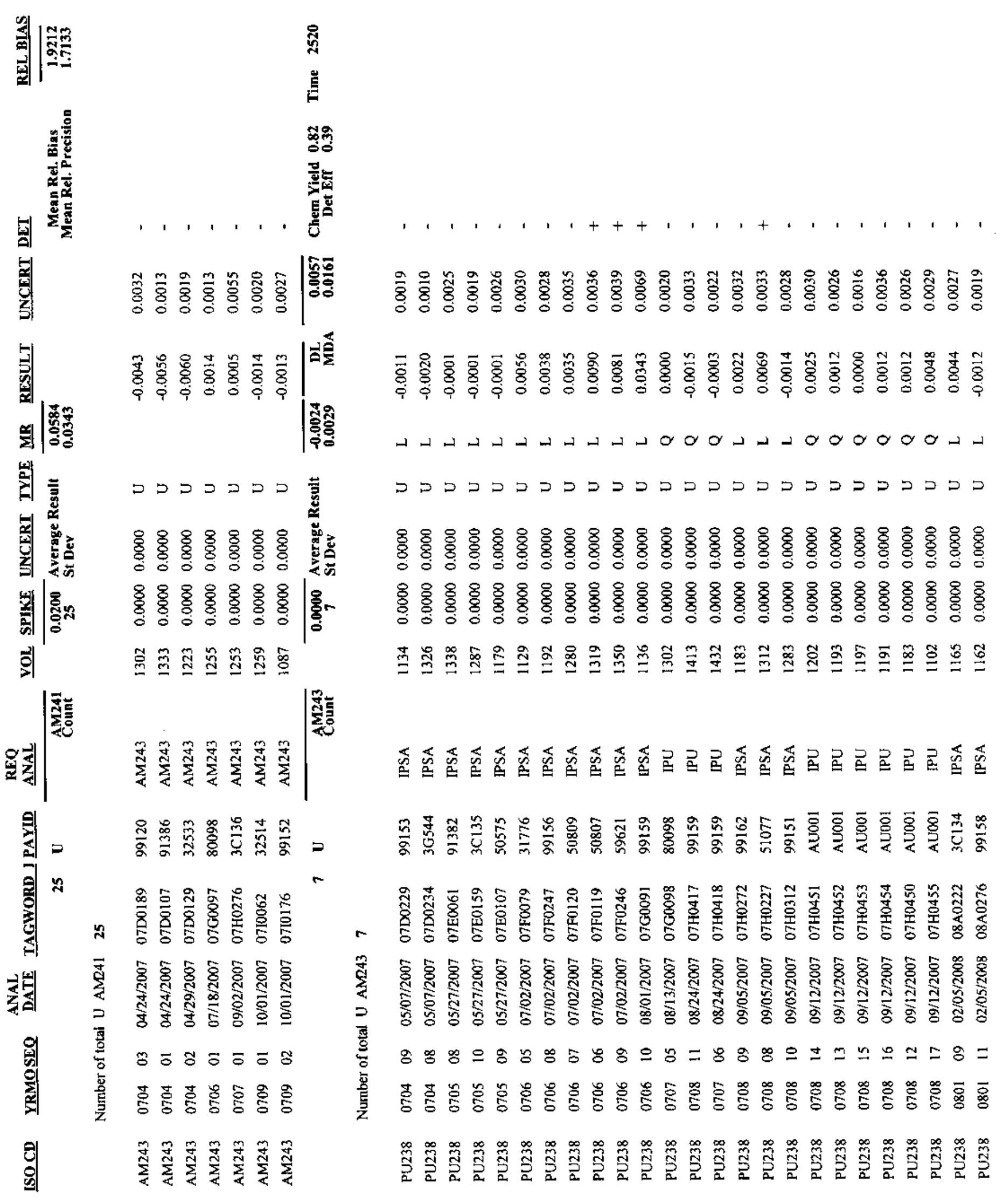




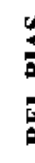

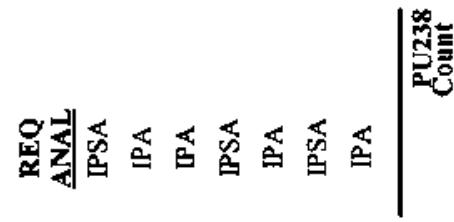

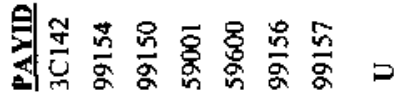

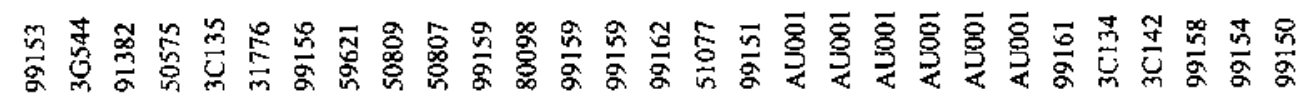
两

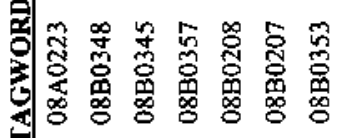
$\Rightarrow$

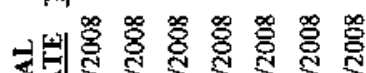

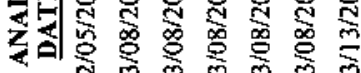

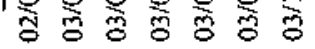

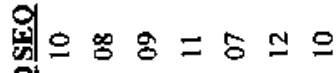

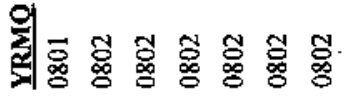

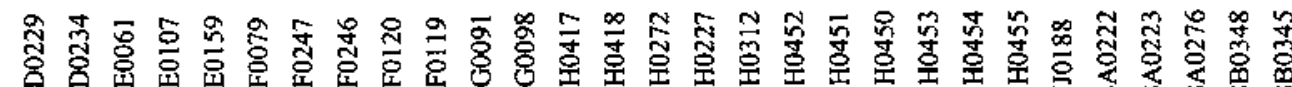

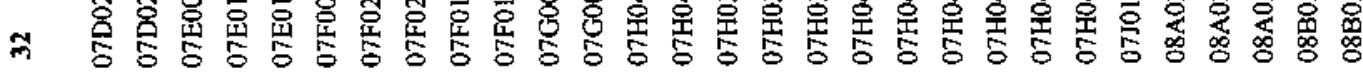

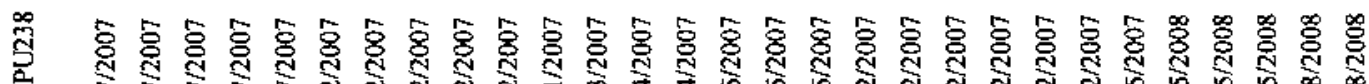

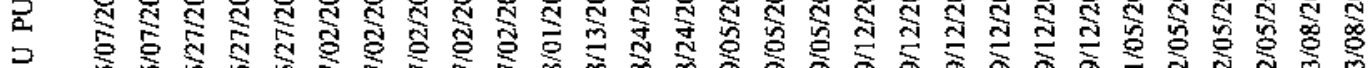

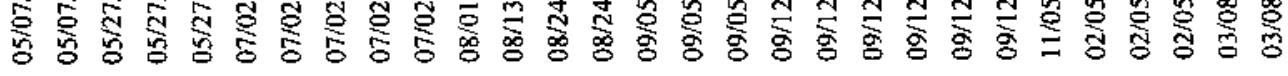

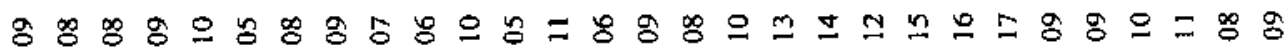

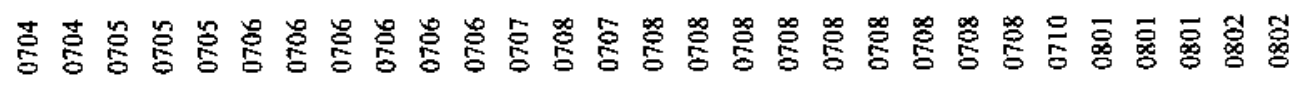

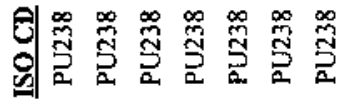

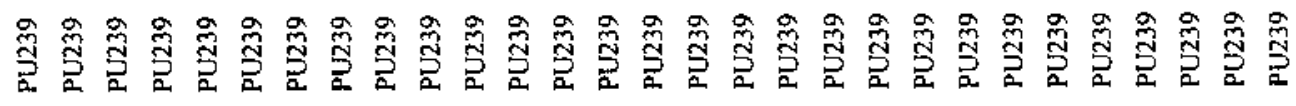




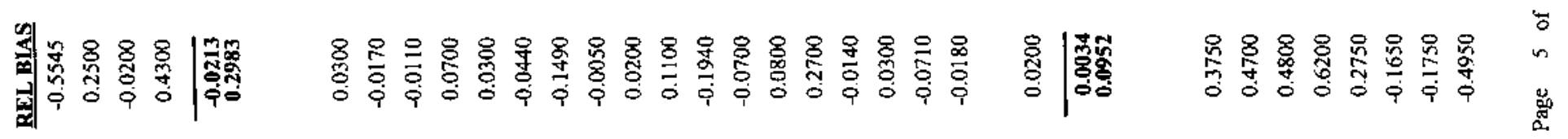

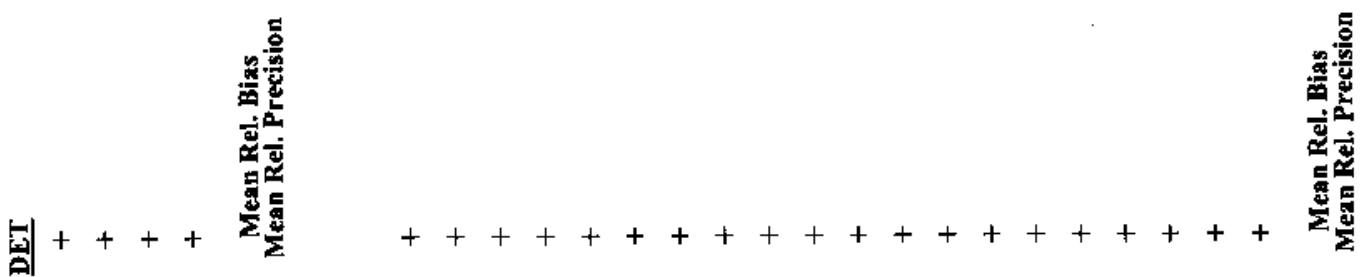

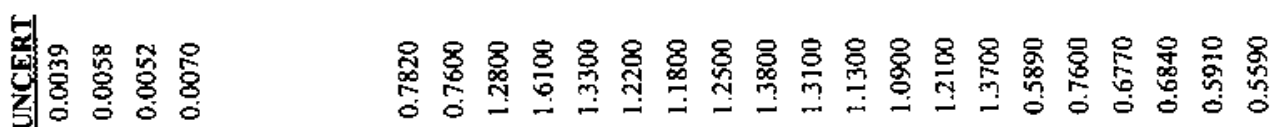

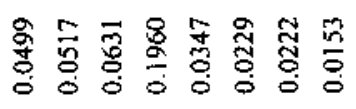

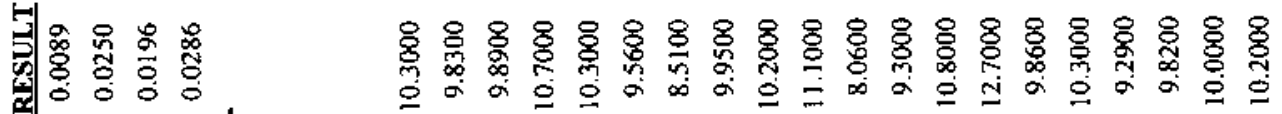
絊

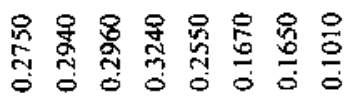

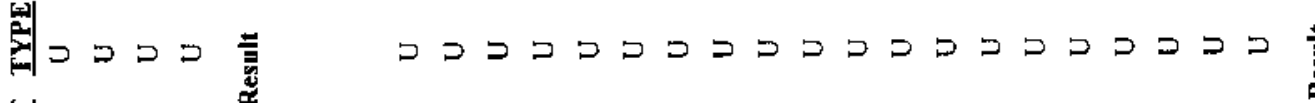

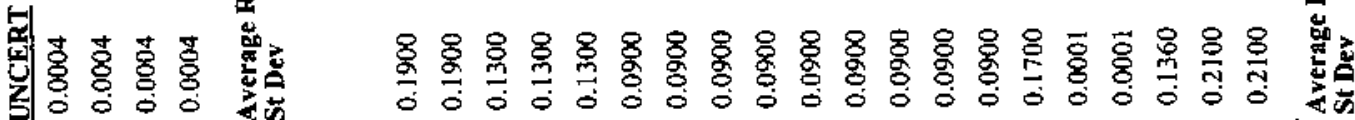

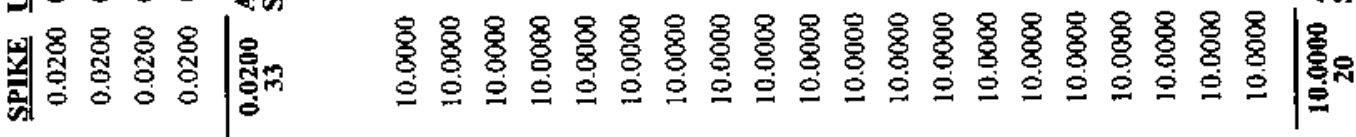

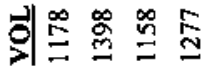

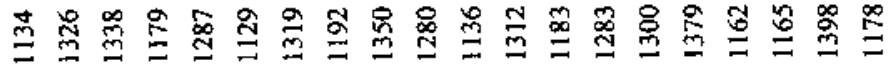

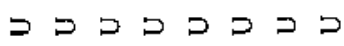

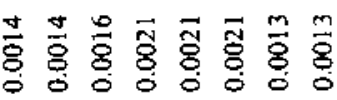

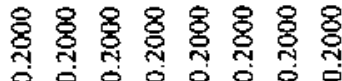

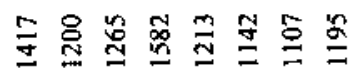

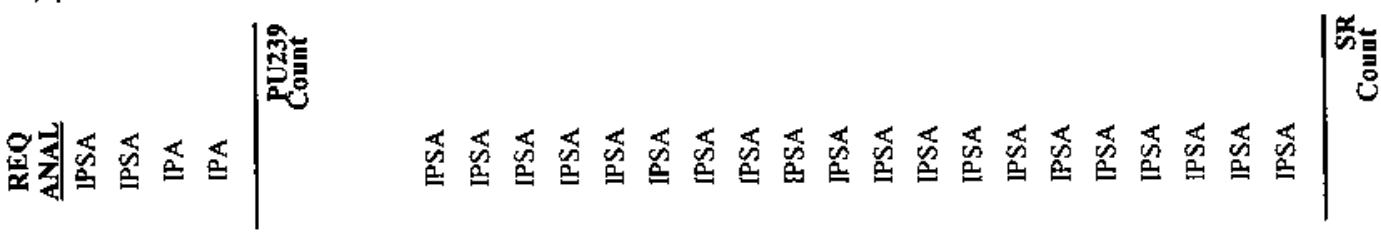

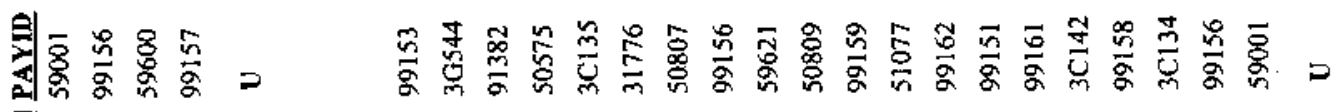

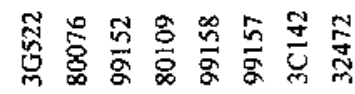

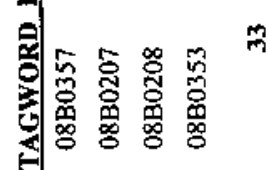

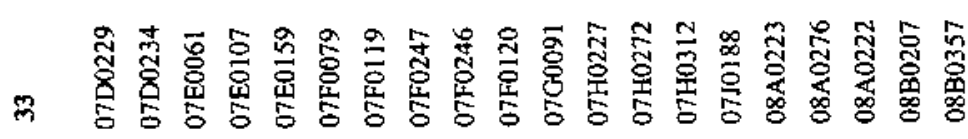

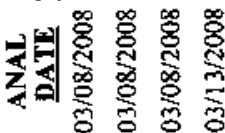

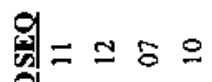

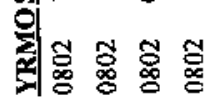

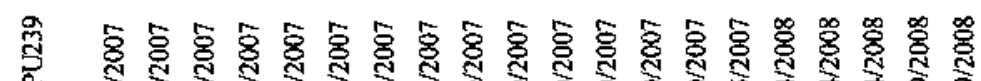

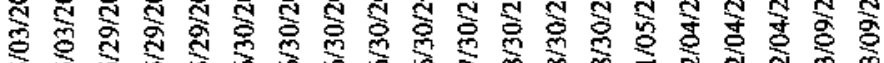

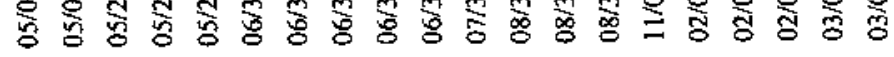

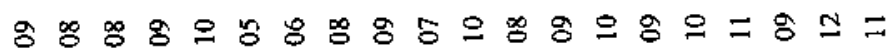

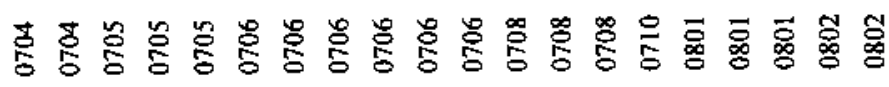
ส

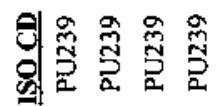

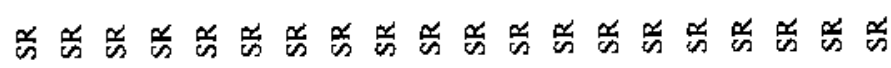

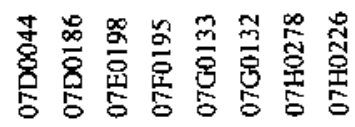

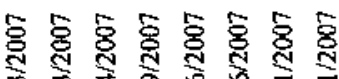

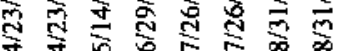

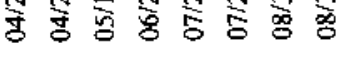

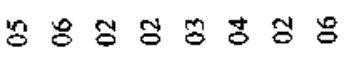

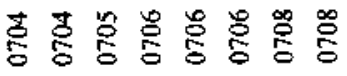
$\operatorname{DDDPDDPD}$ 


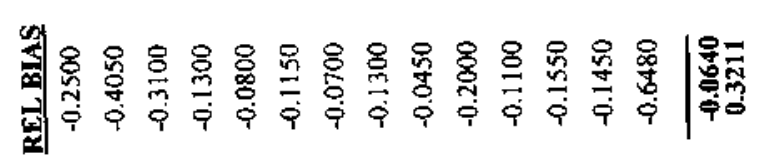

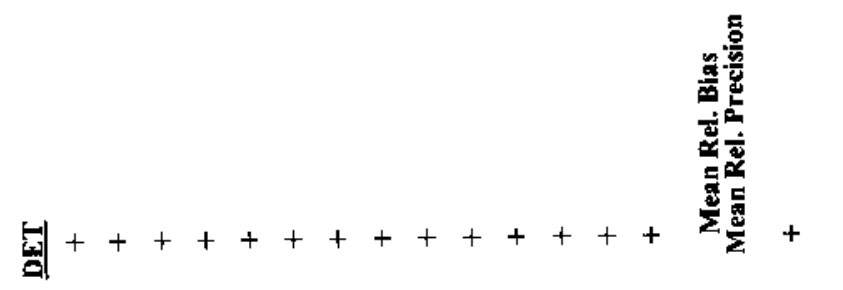

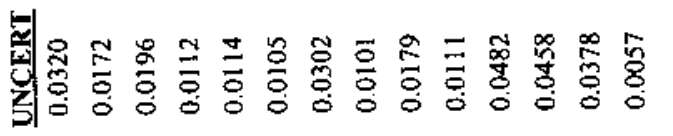

蹇

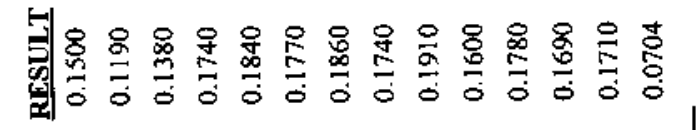

a

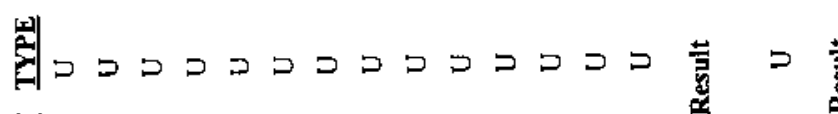

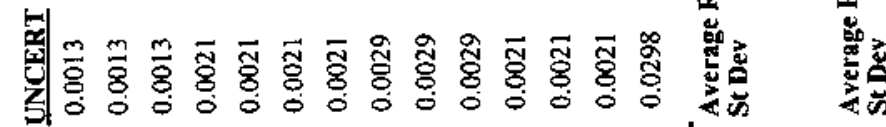

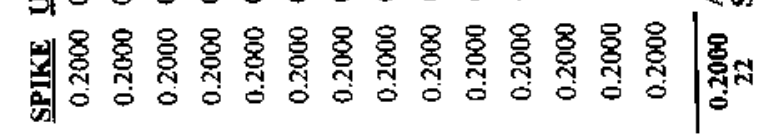

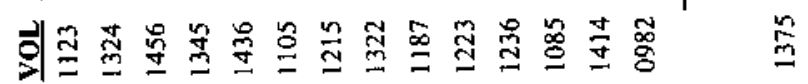

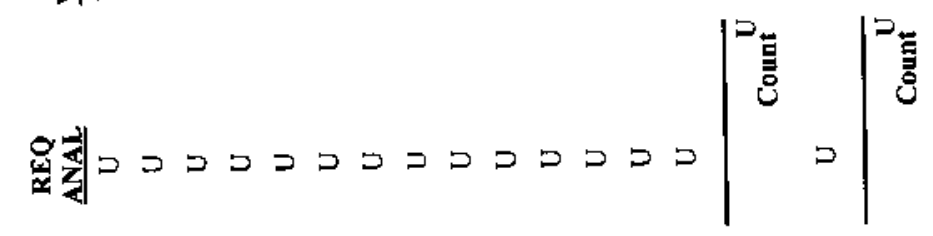

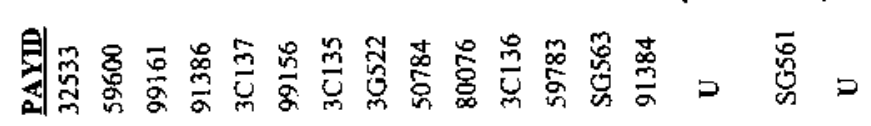

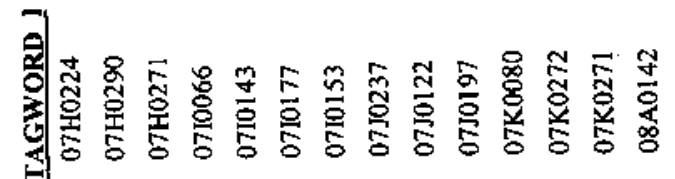

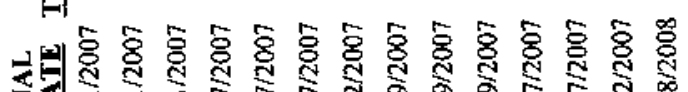

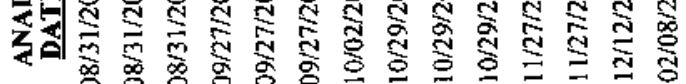

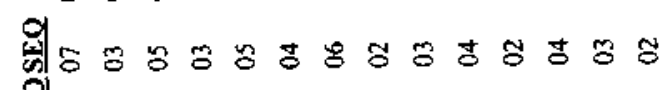

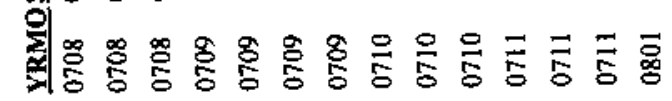

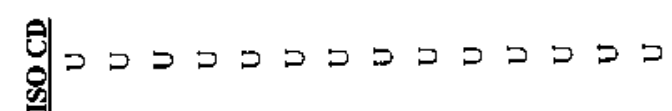

N -

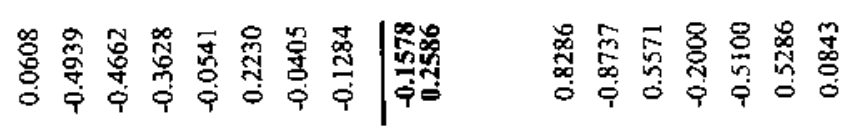

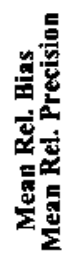

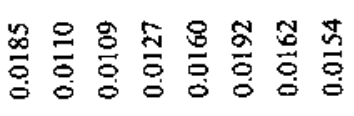

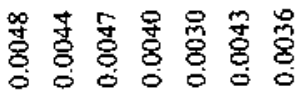

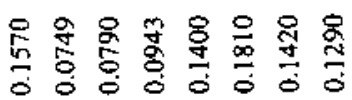

|

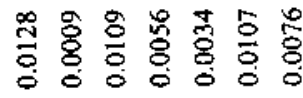

$\supset \supset D D D D$

$D D D D D D D$

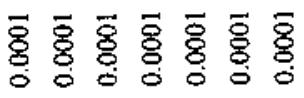

융융융융용용용용

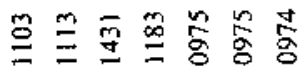

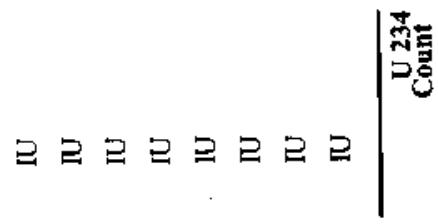

ㅋコㄹㄹ|

$\mid \begin{aligned} & \infty \\ & : \infty\end{aligned}$

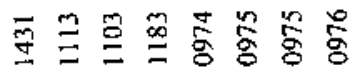

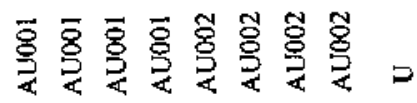

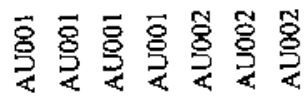

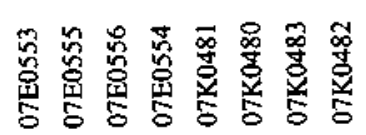

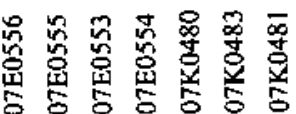

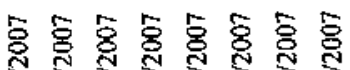

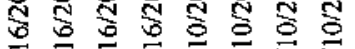

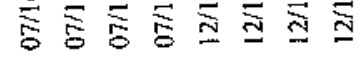

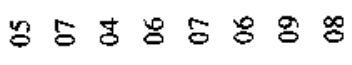

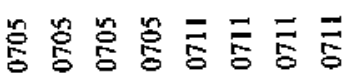

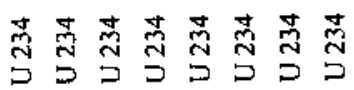

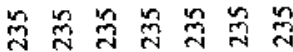




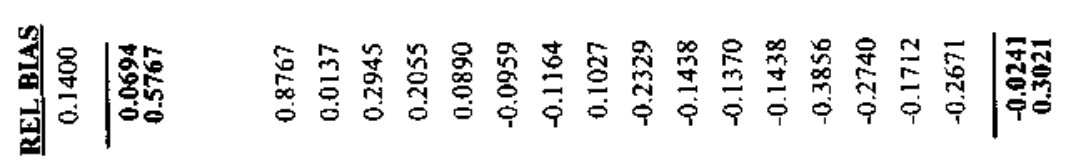

$\infty$ :

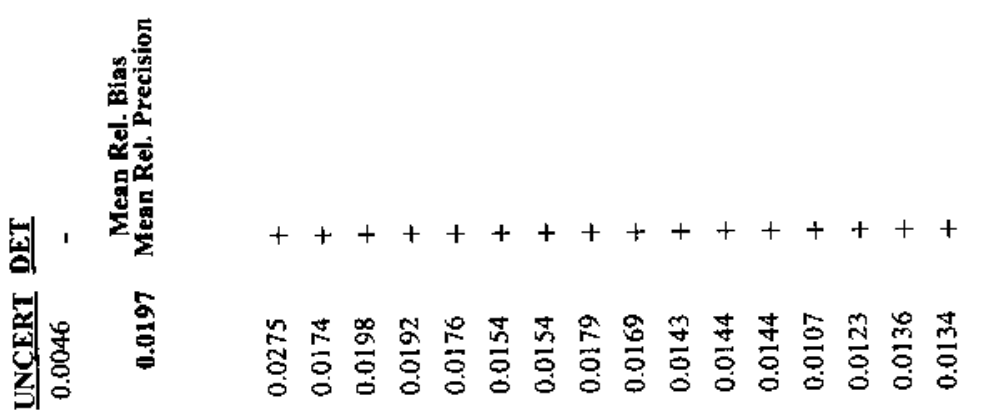

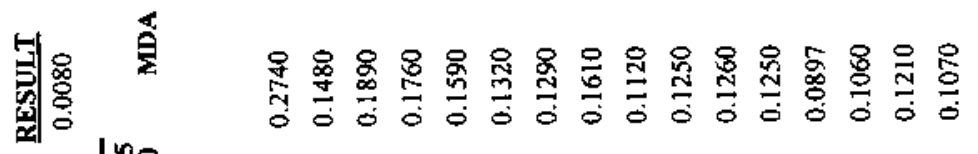

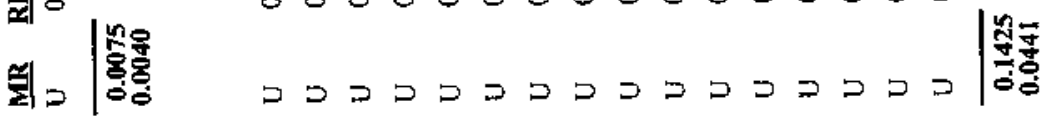

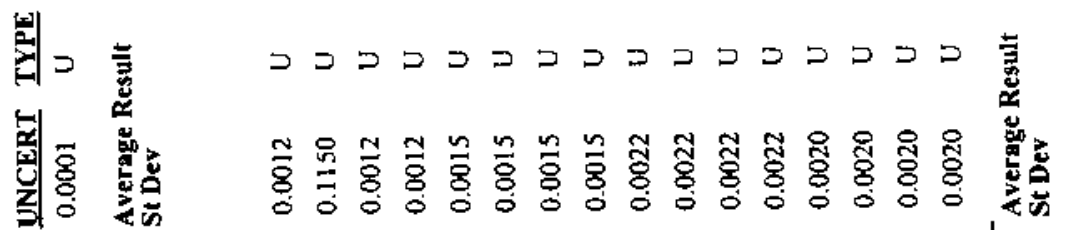

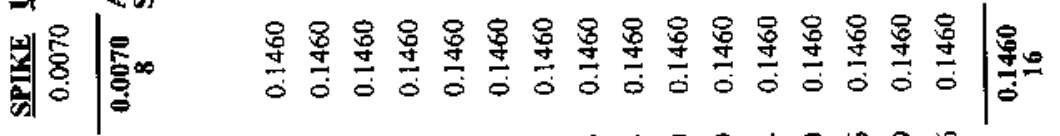

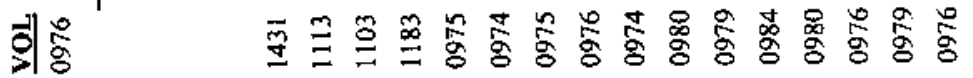

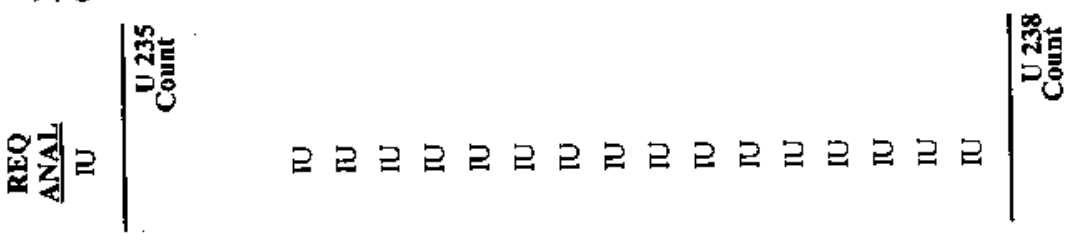

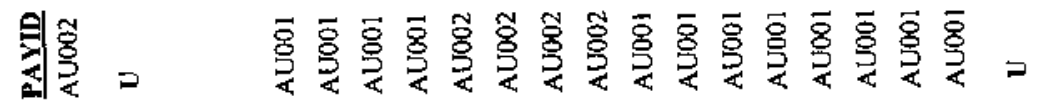

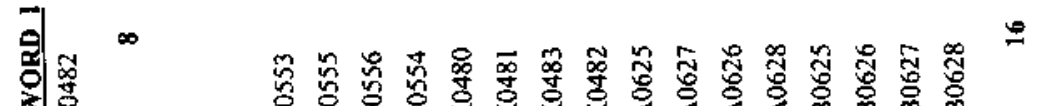

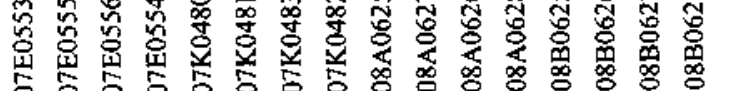

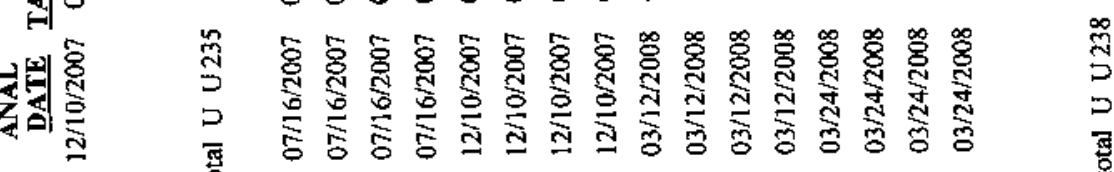

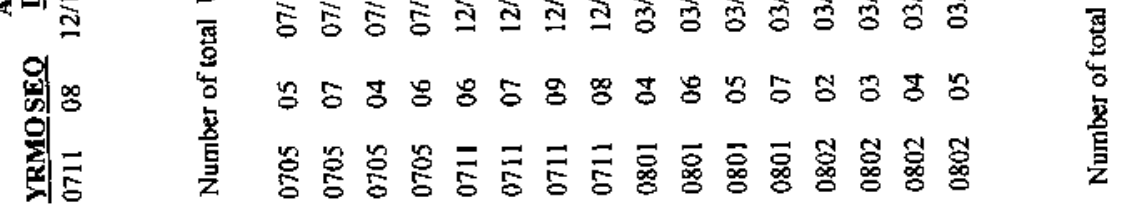

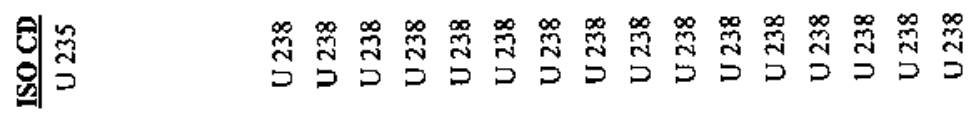




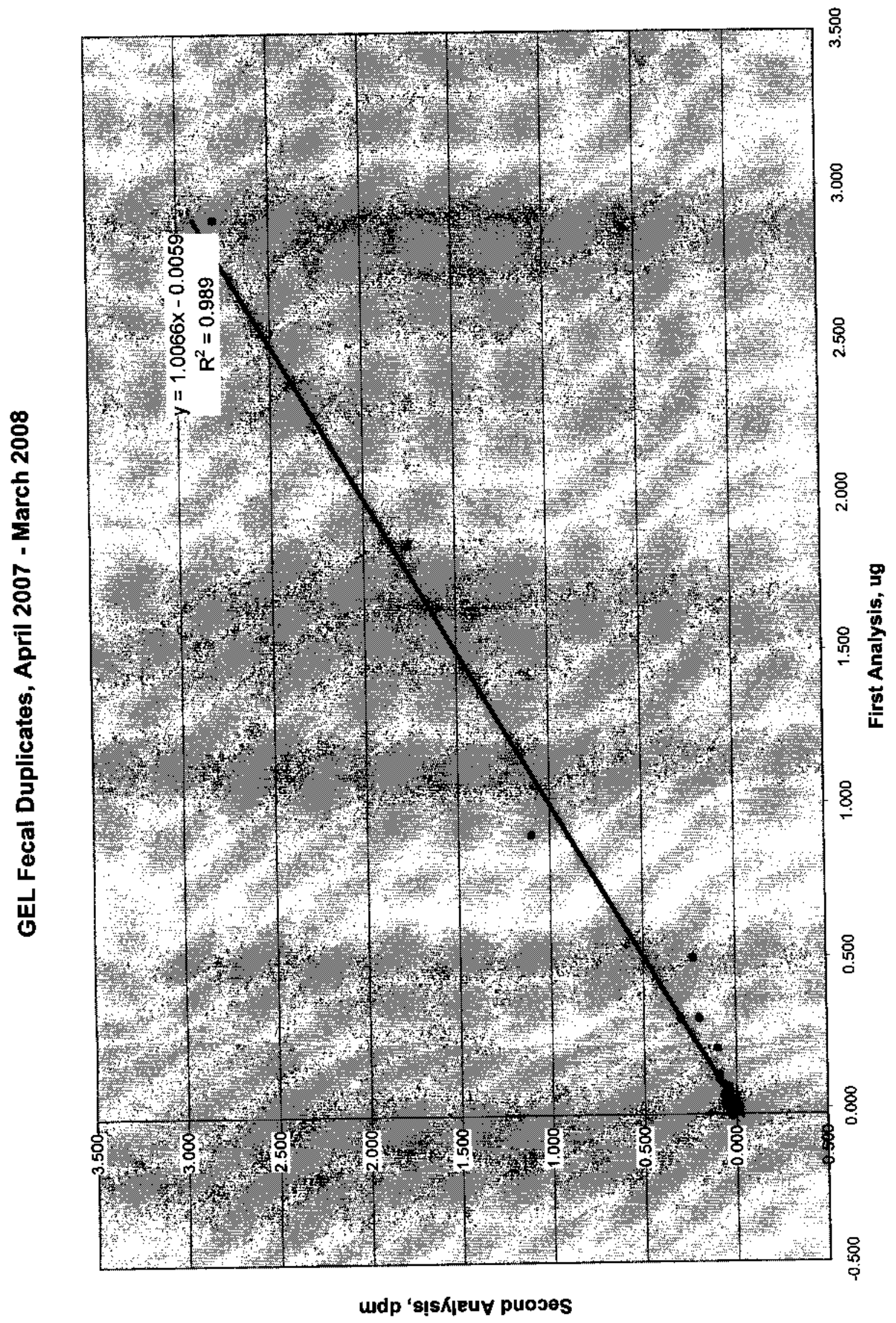


APPENDIX B

GEL QUALITY CONTROL SAMPL.E REPORT SUMMARY

(Historical File Only) 
PNNL

ANNUAL

QC PACKAGE

Contract Year 2007/2008

April 1, 2007 - Mo ' 31, 2008

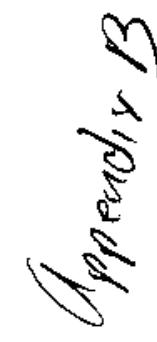


Data was reviewed and found acceptable.

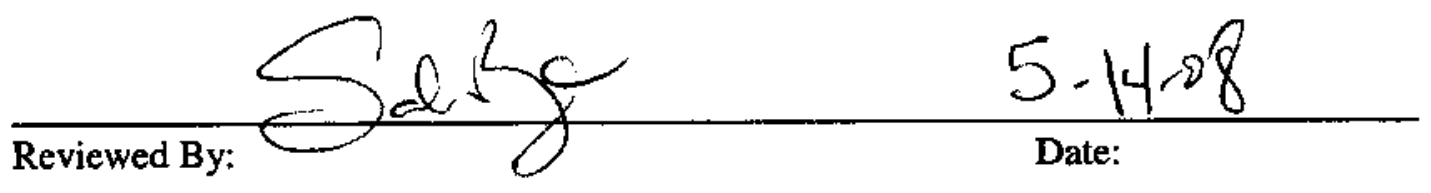

2 


\section{Table of Contents}

Section 1: Case Narrative

Section 2: Database Results

\section{Urine Data}

Am-241 - Blank Activity

Am-241 - LCS Bias High

Am-241 - LCS Bias Low

Am-243 - Blank Activity

Am-243 - Tracer Yield

Am-243 - LCS Bias High

Am-243 - LCS Bias Low

Cm-242 - Blank Activity

Cm-243/244 - Blank Activity

Cm-243/244 - Tracer Yield

Cm-243/244 - LCS Bias High

Cm-243/244 - LCS Bias Low

Pu-238 - Blank Activity

Pu-239/240 - Blank Activity

Pu-239/240 - LCS Bias High

Pu-239/240 - LCS Bias Low

Pu-242 - Tracer Yield

Sr-90 - Blank Activity

Sr-90 - Carrier Yield

Sr-90 - LCS Bias High

Sr-90 - LCS Bias Low

Th-228 - Blank Activity

Th-228 - Tracer Yield

Th-229 - Blank Activity

Th-230 - Blank Activity

Th-232 - Blank Activity

Th-232 - LCS Bias High

Th-232 - LCS Bias Low

Total Sr - Blank Activity

Total Sr-Carrier Yield

Total Sr - LCS Bias High

Total Sr - LCS Bias Low

Total U - Blank Activity

Total U - LCS Bias High

Total U - LCS Bias Low

Tritium - Blank Activity

Tritium - LCS Bias Low

U-232 - Tracer Yield 
U-233/234 - Blank Activity

U-235/236 - Blank Activity

U-238 - Blank Activity

U-238 - LCS Bias High

U-238 - LCS Bias Low

U-236 - Blank Activity

U-236 - LCS Bias Low

U-236 - Tracer Yield

Fecal Data

Am-241 - Blank Activity

Am-241 - Duplicate RER

Am-241 - LCS Bias High

Am-241 - LCS Bias Low

Am-243 - Tracer Yield

Pu-238 - Blank Activity

Pu-238 - Duplicate RER

Pu-239/240 - Blank Activity

Pu-239/240 - Duplicate RER

Pu-239/240 - LCS Bias High

Pu-239/240 - LCS Bias Low

Pu-242 - Tracer Yield

U-232 - Tracer Yield

U-233/234 - Blank Activity

U-233/234 - Duplicate RER

U-235/236 - Blank Activity

U-235/236 - Duplicate RER

U-238 - Blank Activity

U-238 - Duplicate RER

U-238 - LCS Bias High

U-238 - LCS Bias Low

\begin{tabular}{|ll|}
\hline & Legend \\
Samp ID & = the N-value (number of the samples in the data set) \\
Inst & = the analytical instrument ìdentification number/name \\
Run Date & $=$ the sample analysis date \\
LCL & $=$ Lower Control Level (minus 3 sigma) \\
LWL & $=$ Lower Warning Level (minus 2 sigma) \\
Mean & $=$ the average value of the data set
\end{tabular}




$\begin{array}{|ll|}\begin{array}{ll}\text { Numvalue } & \text { Number Value for parameter being monitored } \\ \text { Exclude } & \text { a checked box indicates the data was not used in the calculation of the } \\ & \text { mean and control limits } \\ \text { = Standard Deviation }\end{array} \\ \text { Stdev } & =\text { Upper Warning Level (plus } 2 \text { sigma) } \\ \text { UWL } & =\text { Upper Contol Level (plus } 3 \text { sigma) } \\ \text { UCL } & =\text { the difference of the individual relative bias from the mean } \\ \text { Dispersion } & \text { Parent Sample = the sample that was duplicated } \\ \text { TPU } & =\text { Total Proportion Uncertainty (1 sigma combined standard uncertainty) } \\ \text { RER } & =\text { Relative Error Ratio (the difference of the individual duplicate pairs } \\ \text { Nominal } & \text { based on the combined standard uncertainties of the individual analyses) } \\ \text { Result } & =\text { the calculated concentration of the spike in the sample geometry } \\ \text { Bias } & =\text { the actual measured analyte concentration in the sample }\end{array}$




\section{Statistical Parameters Utilized by The GEL Group, Inc}

\section{Zone Definitions}

Zone $\mathrm{A}$ - Area defined as being between 2 and 3 times sigma above the center line Zone $B$ - Area defined as being between 1 and 2 times sigma above the center line Zone $\mathrm{C}$ - Area defined as being between the center line and 1 times sigma

\section{Data Flag Definitions}

1. Nine (9) points on Zone $\mathrm{C}$ and beyond on one side of the central line - Indicates that the process average may have changed

2. Six (6) points in a row steadily increasing or decreasing on one side of the central line - Indicates that a drift may be occurring in the process average

3. Fourteen (14) points in a row alternating up or down on either side of the center line - If this test is positive it indicates that two systematically alternating causes may be producing different results

4. Two (2) out of three (3) points in a row are in Zone A or beyond - Indicates an early warning of a process shift

5. Four (4) out of five (5) points are in Zone B or beyond - If positive, this, like flag 4, indicates and early warning of a potential process shift

6. Fifteen (15) points are in Zone $C$ above or below the center line - Indicates a smaller variability than expected

7. Eight (8) points in a row are in Zone B, A or beyond on either side of the center line with no points occurring in Zone $\mathrm{C}$ - Indicates that different samples are affected by different factors resulting in bimodal distribution of averages

\section{References}

Statistica Software - Data Mining, Statistical Analysis and Quality Control

Quality Control Charts - www.statsoft.com/textbook/stquacon.html 
SECTION 1

CASE NARRATIVE 


\section{$4^{\text {th }}$ Quarter QC Report - Operational Year 2007}

This report summarizes Quality Control Samples (QC) analyzed with bioassay samples under Contract 11530 during the Contract Year 2007, beginning April 1, 2007 and ending March 31, 2008. Included in the report are listings for the blank, duplicate and spike results. A description of the attached data is provided below. 6303 reported samples were analyzed under this contract with a run date during the annual quarter including failed analyses, recounts, and reanalyses. The QC samples include blanks, spikes, and duplicates.

\section{PNNL Sample/QC Summary}

\begin{tabular}{|l|l|l|l|l|l|l|}
\hline \multicolumn{1}{|c}{$\begin{array}{c}\text { Test } \\
\text { Description }\end{array}$} & Matrix & $\begin{array}{l}\text { Reported } \\
\text { Samples }\end{array}$ & $\begin{array}{c}\text { QC } \\
\text { Samples }\end{array}$ & $\begin{array}{c}\text { Total } \\
\text { Samples }\end{array}$ & $\%$ QC \\
\hline Americium & Fecal & 58 & 86 & 144 & 60 \\
\hline Uranium & Fecal & 3 & 7 & 10 & 70 \\
\hline Plutonium & Fecal & 91 & 116 & 207 & 56 \\
\hline Americium-243 & Urine & 89 & 84 & 173 & 49 \\
\hline Thorium & Urine & 1 & 8 & 9 & 89 \\
\hline Uranium by ICPMS & Urine & 1 & 3 & 4 & 75 \\
\hline Americium & Urine & 796 & 463 & 1259 & 37 \\
\hline Plutonium & Urine & 2750 & 1261 & 4011 & 31 \\
\hline Strontium 90 & Urine & 798 & 384 & 1182 & 32 \\
\hline Total Strontium & Urine & 36 & 63 & 99 & 64 \\
\hline Total Uranium & Urine & 334 & 462 & 796 & 58 \\
\hline Tritium & Urine & 816 & 282 & 1098 & 26 \\
\hline Uranium & Urine & 529 & 243 & 772 & 31 \\
\hline Totals & & 6303 & 3465 & 9768 & 35 \\
\hline
\end{tabular}

\section{BJanks}

The following table contains the analyses, isotope, matrix, and the calculated MDAs. The alpha spectrometry MDAs are based on the average blank counts and average tracer yields for the quarter. The Strontium MDAs are adjusted according to the average tracer yield for the quarter. The total uranium MDAs are based on the standard deviation of the $0.05 \mathrm{ug} / \mathrm{L}$ standard analyzed each day throughout the quarter. 


\begin{tabular}{|c|c|c|c|c|c|c|c|c|c|}
\hline Isotope & Matrix & N\# & MDA & Le & $\begin{array}{c}\text { Avg. } \\
\text { Volume }\end{array}$ & $\begin{array}{c}\text { Sample } \\
\text { units }\end{array}$ & $\begin{array}{c}\text { Detector } \\
\text { Yleld }\end{array}$ & $\begin{array}{c}\text { Count } \\
\text { Efticlency }\end{array}$ & $\begin{array}{l}\text { Time } \\
(\min )\end{array}$ \\
\hline$A m-241$ & Urine & 155 & 0.011 & 0.00447 & 1 & $\mathrm{dpm} / \mathrm{s}$ & 0.816 & 0.391 & 2520 \\
\hline$A m-243$ & Urine & 38 & 0.013 & 0.00506 & 1 & $\mathrm{dpm} / \mathrm{s}$ & 0.8709 & 0.391 & 2520 \\
\hline $\begin{array}{c}\mathrm{Cm}-242 \\
\mathrm{Cm}-\end{array}$ & Urine & 38 & 0.011 & 0.00413 & 1 & $\mathrm{dpm} / \mathrm{s}$ & 0.816 & 0.391 & 2520 \\
\hline $243 / 244$ & Urine & 155 & 0.010 & 0.00410 & 1 & $\mathrm{dpm} / \mathrm{s}$ & 0.816 & 0.391 & 2520 \\
\hline $\begin{array}{c}\text { Pu-238 } \\
\text { Pu- }\end{array}$ & Urine & 426 & 0.010 & 0.00403 & 1 & $\mathrm{dpm} / \mathrm{s}$ & 0.89 & 0.391 & 2520 \\
\hline $239 / 240$ & Urine & 426 & 0.011 & 0.00450 & 1 & $\mathrm{dpm} / \mathrm{s}$ & 0.89 & 0.391 & 2520 \\
\hline Th-228 & Urine & 6 & 0.044 & 0.02953 & 1 & $\mathrm{dpm} / \mathrm{s}$ & 0.8804 & 0.386 & 2520 \\
\hline Th-229 & Urine & 6 & 0.032 & 0.02137 & 1 & $\mathrm{dpm} / \mathrm{s}$ & 0.8804 & 0.386 & 2520 \\
\hline Th-230 & Urine & 6 & 0.036 & 0.02137 & 1 & $\mathrm{dpm} / \mathrm{s}$ & 0.8804 & 0.386 & 2520 \\
\hline Th-232 & Urine & 6 & 0.012 & 0.00630 & 1 & $\mathrm{dpm} / \mathrm{s}$ & 0.880 & 0.386 & 2520 \\
\hline U-233/234 & Urine & 80 & 0.021 & 0.00962 & 1 & $\mathrm{dpm} / \mathrm{s}$ & 0.834 & 0.386 & 2520 \\
\hline U-235/236 & Urine & 80 & 0.016 & 0.00669 & 1 & $\mathrm{dpm} / \mathrm{s}$ & 0.834 & 0.386 & 2520 \\
\hline U-238 & Urine & 80 & 0.020 & 0.00898 & 1 & $\mathrm{dpm} / \mathrm{s}$ & 0.834 & 0.386 & 2520 \\
\hline$U-236$ & Urine & 1 & $9.55 \mathrm{E}-05$ & 0.00000 & $1 \mathrm{~L}$ & ugll. & $n / a$ & $n / a$ & $\mathrm{n} / \mathrm{a}$ \\
\hline Sr-90 & Urine & 127 & 2.32 & 0.61810 & 1 & $\mathrm{dpm} / \mathrm{s}$ & 0.789 & 0.379 & 60 \\
\hline Total Sr & Urine & 20 & 2.82 & 0.31600 & 1 & $\mathrm{dpm} / \mathrm{s}$ & 0.788 & 0.379 & 60 \\
\hline Tritium & Urine & 141 & 996 & 8.55251 & $0.01 \mathrm{~L}$ & $\mathrm{dpm} /$ & $n / a$ & 0.243 & 20 \\
\hline Total U & Urine & 225 & 0.011 & 0.00632 & $0.05 \mathrm{~L}$ & $u g / s$ & $\mathrm{n} / \mathrm{a}$ & n/a & $n / a$ \\
\hline$A m-241$ & Fecal & 24 & 0.062 & 0.00514 & 0.3333 & $\mathrm{dpm} / \mathrm{s}$ & 0.757 & 0.391 & 960 \\
\hline $\begin{array}{l}\text { Pu-238 } \\
\text { Pu- }\end{array}$ & Fecal & 34 & 0.069 & 0.00774 & 0.3333 & $\mathrm{dpm} / \mathrm{s}$ & 0.847 & 0.391 & 960 \\
\hline $239 / 240$ & Fecal & 34 & 0.076 & 0.00801 & 0.3333 & $\mathrm{dpm} / \mathrm{s}$ & 0.847 & 0.391 & 960 \\
\hline U-233/234 & Fecal & 2 & 0.149 & 0.01465 & 0.3333 & $\mathrm{dpm} / \mathrm{s}$ & 0.808 & 0.386 & 960 \\
\hline U-235 & Fecal & 2 & 0.085 & 0.00546 & 0.3333 & $\mathrm{dpm} / \mathrm{s}$ & 0.808 & 0.386 & 960 \\
\hline U-238 & Fecal & 2 & 0.112 & 0.00799 & 0.3333 & $\mathrm{dpm} / \mathrm{s}$ & 0.808 & 0.386 & 960 \\
\hline
\end{tabular}

All analytical batches were analyzed with either a reagent blank, matrix blank or both. Blanks are in control when the calculated MDA and blank activity are both less than CRDL (contract required detection limit). In addition, the chemical tracer yields are evaluated against the yield requirements stated in the subject contract. Overall, the blank data for each analytical process demonstrate the analyses were in control. Processing categories and samples which did not meet contractual requirements are discussed in the Observations section of this report.

\section{Laboratory Control Samples (LCS)}

The enclosed listing contains the analysis isotope, matrix, average relative bias and the relative precision statistic. One or more LCS sample was analyzed with each batch of samples. 


\begin{tabular}{|l|l|l|l|l|l|l|}
\hline \multicolumn{1}{|c|}{ Test } & Matrix & $\begin{array}{c}\text { Number } \\
\text { In Set } \\
\text { (N\#) }\end{array}$ & $\begin{array}{c}\text { Range } \\
\text { High(1)(2) }\end{array}$ & $\begin{array}{c}\text { Average } \\
\text { Nominal } \\
\text { (dpm/sample) }\end{array}$ & $\begin{array}{c}\text { Average } \\
\text { Relative } \\
\text { Bias }\end{array}$ & $\begin{array}{l}\text { Relative } \\
\text { Precision }\end{array}$ \\
\hline Americium-241 & Fecal & 19 & High(1) & 3.87 & .00537 & .0892 \\
\hline Plutonium-239/240 & Fecal & 25 & High(1) & 9.05 & .0545 & .0568 \\
\hline Uranium-238 & Fecal & 2 & High(2) & 5.7 & 105 & .005 \\
\hline Americium-241 & Urine & 157 & High(1) & .335 & .0534 & .107 \\
\hline Americium-243 & Urine & 37 & High(1) & .513 & -.0132 & .0971 \\
\hline Curium-243/244 & Urine & 38 & High(1) & .331 & .0651 & .0947 \\
\hline Plutonium-239/240 & Urine & 454 & High(1) & .444 & -.0014 & .0723 \\
\hline Strontium-90 & Urine & 133 & High(1) & 36.6 & .0149 & .103 \\
\hline Thorium-232 & Urine & 1 & High(1) & 2.15 & -.042 & 0 \\
\hline Total Strontium & Urine & 20 & High (1) & 16.46 & -0.0098 & 0.057 \\
\hline Total Uranium & Urine & 75 & High(1) & 1 ug/L & -.124 & .117 \\
\hline Tritium & Urine & 141 & High(1) & $17000 \mathrm{dpm} / \mathrm{L}$ & -.0147 & .0675 \\
\hline Uranium-238 & Urine & 82 & High(2) & .422 & -.049 & .108 \\
\hline
\end{tabular}

(1) High range: nominal $>2 x$ the Contractual Detection Level (CL)

(2) High range for U-238: nominal >0.34 dpm/sample

*Unless otherwise noted.

\begin{tabular}{|c|c|c|c|c|c|c|c|}
\hline Test & Matrix & $\begin{array}{c}\text { Number } \\
\text { In Set } \\
\text { (N*) }\end{array}$ & $\begin{array}{c}\text { Range } \\
\text { Low(1)(2)(3) }\end{array}$ & $\begin{array}{c}\text { Average } \\
\text { Nominal } \\
\text { (Apm/sample) }\end{array}$ & $\begin{array}{l}\text { Number } \\
\text { Below Le }\end{array}$ & $\begin{array}{c}\text { Average } \\
\text { Relative } \\
\text { Bins }\end{array}$ & $\begin{array}{l}\text { Relative } \\
\text { Prectsion }\end{array}$ \\
\hline $\begin{array}{l}\text { Americium- } \\
241\end{array}$ & Fecal & 21 & Low(1) & .554 & 1 & 106 & .195 \\
\hline $\begin{array}{l}\text { Plutonium- } \\
239 / 240\end{array}$ & Fecal & 31 & Low(1) & .214 & 0 & .17 & 0 \\
\hline \begin{tabular}{|l} 
Uranium- \\
238
\end{tabular} & Fecal & 2 & Low(3) & .339 & 0 & .514 & .536 \\
\hline \begin{tabular}{|l} 
Americium- \\
241
\end{tabular} & Urine & 146 & Low(1) & .0209 & 0 & .122 & .316 \\
\hline \begin{tabular}{|l} 
Americium- \\
243
\end{tabular} & Urine & 17 & Low(1) & .0203 & 10 & .196 & .321 \\
\hline $\begin{array}{l}\text { Curium- } \\
243 / 244\end{array}$ & Urine & 30 & Low(1) & .025 & 0 & .187 & .281 \\
\hline $\begin{array}{l}\text { Plutonium- } \\
239 / 240\end{array}$ & Urine & 378 & Low(1) & .0223 & 4 & .0164 & .267 \\
\hline
\end{tabular}




\begin{tabular}{|c|c|c|c|c|c|c|c|}
\hline $\begin{array}{l}\text { Strontium- } \\
90\end{array}$ & Urine & 123 & Low $(1)$ & 10.4 & 0 & -.0189 & 1474 \\
\hline $\begin{array}{l}\text { Thorium- } \\
232\end{array}$ & Urine & 1 & Low $(1)^{\prime}$ & .108 & 0 & .05 & 0 \\
\hline $\begin{array}{l}\text { Total } \\
\text { Strontium }\end{array}$ & Urine & 20 & Low (1) & 4.68 & 0 & .0451 & .1344 \\
\hline $\begin{array}{l}\text { Total } \\
\text { Uranium }\end{array}$ & Urine & 74 & Low (1) & .0839 & 0 & -.122 & .2 \\
\hline $\begin{array}{l}\text { Uranium- } \\
236\end{array}$ & Urine & 1 & Low(1) & $.05 \mathrm{ug} / \mathrm{L}$ & 0 & -.0498 & 0 \\
\hline $\begin{array}{l}\text { Uranium- } \\
238\end{array}$ & Urine & 78 & $\operatorname{Low}(3)$ & .127 & 1 & -.0405 & .219 \\
\hline
\end{tabular}

(1) Low range: nominal * the Contractual Detection Level (CL)

(3) Low range for U-238: nominal $<0.34 \mathrm{dpm} / \mathrm{sample}$

*Unless otherwise noted.

Overall, the LCS data demonstrates the analytical processes were in control. Any LCS outside the limits is discussed in the Observations section of this report.

\section{Duplicate Samples (DUP)}

The duplicate samples were evaluated to determine that the aliquot procedure produces results within the RER limits of 0 to 3 .

\section{Americium-241}

\begin{tabular}{|c|c|c|c|c|c|c|c|c|c|c|}
\hline$\#$ & Sample ID & Inst & $\begin{array}{l}\text { Run } \\
\text { Date }\end{array}$ & $\begin{array}{l}\text { Tracer } \\
\text { Yield }\end{array}$ & Mear & RER & $\mathbf{T P U}$ & $\begin{array}{l}\text { Parent } \\
\text { Sample }\end{array}$ & Result & TPU \\
\hline 1 & 1201449893 & 1700 & $\begin{array}{l}08- \\
\text { NOV- } \\
07\end{array}$ & .73 & .831 & 1.41 & .0295 & 196602001 & $\begin{array}{l}.0701 \\
\text { and } \\
.0234\end{array}$ & $\begin{array}{l}.0295 \\
\text { and } \\
.0148\end{array}$ \\
\hline 2 & 1201403069 & 1703 & $\begin{array}{l}05- \\
\text { SEP- } \\
07\end{array}$ & .765 & .831 & .63 & .24 & 192329001 & 1.11 and & $\begin{array}{l}.24 \text { and } \\
.203\end{array}$ \\
\hline 3 & 1201464614 & 1680 & $\begin{array}{l}15- \\
\text { DEC- } \\
07\end{array}$ & .817 & .831 & .117 & 172 & 197975001 & $\begin{array}{l}.821 \text { and } \\
.85\end{array}$ & $\begin{array}{l}.172 \\
\text { and } \\
179\end{array}$ \\
\hline 4 & 1201495192 & 1673 & $\begin{array}{l}21- \\
\text { JAN- } \\
08\end{array}$ & .77 & 831 & .0405 & .071 & 200812001 & $\begin{array}{l}257 \text { and } \\
253\end{array}$ & $\begin{array}{l}.071 \\
\text { and } \\
.0686\end{array}$ \\
\hline & & & & & & & & & & \\
\hline 5 & 1201478005 & 1659 & 18. & .563 & 831 & 1.55 & .00834 & 199166001 & -.00964 & .00834 \\
\hline
\end{tabular}




\begin{tabular}{|c|c|c|c|c|c|c|c|c|c|c|}
\hline & & & $\begin{array}{l}\text { DEC- } \\
07\end{array}$ & & & & & & $\begin{array}{l}\text { and } \\
.00556\end{array}$ & $\begin{array}{l}\text { and } \\
.00514\end{array}$ \\
\hline 6 & 1201347902 & 1667 & $\begin{array}{l}13- \\
\text { JUN- } \\
07\end{array}$ & .739 & .831 & .559 & .0261 & 187075001 & $\begin{array}{l}.0621 \\
\text { and } \\
.0414\end{array}$ & $\begin{array}{l}.0261 \\
\text { and } \\
.0263\end{array}$ \\
\hline 7 & 1201349152 & 1679 & $\begin{array}{l}15- \\
\pi N- \\
07\end{array}$ & 842 & .831 & .591 & .0151 & 187164001 & $\begin{array}{l}.0136 \\
\text { and - } \\
.00442\end{array}$ & $\begin{array}{l}.0151 \\
\text { and } \\
.00364\end{array}$ \\
\hline 8 & 1201350782 & 1646 & $\begin{array}{l}16- \\
J U N- \\
07\end{array}$ & .766 & .831 & 1.35 & .00597 & 187371001 & $\begin{array}{l}.00992 \\
\text { and - } \\
.00104\end{array}$ & $\begin{array}{l}.00597 \\
\text { and } \\
.00271\end{array}$ \\
\hline 9 & 1201354251 & 1697 & $\begin{array}{l}19 \\
\int U N- \\
07\end{array}$ & .683 & 831 & 1.23 & .0342 & 187443001 & $\begin{array}{l}0821 \\
\text { and .162 }\end{array}$ & $\begin{array}{l}.0342 \\
\text { and } \\
.0555\end{array}$ \\
\hline 10 & 1201360628 & 1635 & $\begin{array}{l}28- \\
\mathrm{JUN}- \\
07\end{array}$ & .883 & .831 & 1.88 & .00263 & 188127001 & \begin{tabular}{|l|}
.00224 \\
and - \\
.00471
\end{tabular} & $\begin{array}{l}.00263 \\
\text { and } \\
.0026\end{array}$ \\
\hline 11 & 1201387026 & 1678 & $\begin{array}{l}11- \\
\text { AUG- } \\
07\end{array}$ & .298 & .831 & .364 & .011 & 190622002 & $\begin{array}{l}.00117 \\
\text { and - } \\
.00306\end{array}$ & \begin{tabular}{|l}
.011 \\
and \\
.00379 \\
\end{tabular} \\
\hline 12 & 1201403899 & 1636 & $\begin{array}{l}06- \\
\text { SEP- } \\
07\end{array}$ & .744 & .831 & 1.56 & .0123 & 192440001 & $\begin{array}{l}-.0145 \\
\text { and } \\
00638\end{array}$ & $\begin{array}{l}.0123 \\
\text { and } \\
.00532\end{array}$ \\
\hline 13 & 1201407277 & 1624 & $\begin{array}{l}10- \\
\text { SEP- } \\
07\end{array}$ & .685 & .831 & .444 & .00553 & 192741001 & $\begin{array}{l}.00663 \\
\text { and } \\
.0108\end{array}$ & $\begin{array}{l}.00553 \\
\text { and } \\
.00758\end{array}$ \\
\hline 14 & 1201437503 & 1687 & \begin{tabular}{|l}
$07-$ \\
NoV- \\
07
\end{tabular} & .681 & .831 & .498 & 00491 & 195471001 & $\begin{array}{l}-.00387 \\
\text { and - } \\
.0203 \\
\end{array}$ & $\begin{array}{l}.00491 \\
\text { and } \\
.0326\end{array}$ \\
\hline 15 & 1201440105 & 1697 & $\begin{array}{l}20- \\
\text { OCT- } \\
07\end{array}$ & .732 & .831 & .674 & 00473 & 195489001 & $\begin{array}{l}-.00186 \\
\text { and - } \\
.00816\end{array}$ & $\begin{array}{l}.00473 \\
\text { and } \\
.00807\end{array}$ \\
\hline 16 & 1201518599 & 1653 & $\begin{array}{l}27- \\
\text { FEB- } \\
08\end{array}$ & .844 & .831 & .389 & .0387 & 203019001 & .112 and & $\begin{array}{l}.0387 \\
\text { and } \\
.0339\end{array}$ \\
\hline
\end{tabular}


Plutonium-238

\begin{tabular}{|c|c|c|c|c|c|c|c|c|c|c|}
\hline$\#$ & Sample $\mathbf{D}$ & Inst & $\begin{array}{l}\text { Run } \\
\text { Date }\end{array}$ & $\begin{array}{l}\text { Tracer } \\
\text { Yleld }\end{array}$ & Meen & RER & TPU & $\begin{array}{l}\text { Parent } \\
\text { Sample }\end{array}$ & Result & TPU \\
\hline 1 & 1201366796 & 1677 & $\begin{array}{l}09- \\
\text { JUL- } \\
07\end{array}$ & .974 & .718 & .531 & .235 & 188743001 & $\left\{\begin{array}{l}2.76 \text { and } \\
2.59\end{array}\right.$ & $\begin{array}{l}.235 \\
\text { and } \\
.217\end{array}$ \\
\hline 2 & 1201449897 & 1680 & $\begin{array}{l}07- \\
\text { NOV- } \\
07\end{array}$ & .933 & .718 & .952 & .00518 & 196602001 & $\begin{array}{l}.00206 \\
\text { and } \\
0139\end{array}$ & $\begin{array}{l}.00518 \\
\text { and } \\
0113\end{array}$ \\
\hline 3 & 1201403073 & 1643 & $\begin{array}{l}04 \\
\text { SEP- } \\
07\end{array}$ & .685 & .718 & 1.59 & .00717 & 192329001 & $\begin{array}{l}.0011 \\
\text { and } \\
.0329\end{array}$ & $\begin{array}{l}.00717 \\
\text { and } \\
0187 \\
\end{array}$ \\
\hline 4 & 1201464618 & 1699 & $\begin{array}{l}13- \\
\text { DEC- } \\
07\end{array}$ & 1.01 & .718 & 1.48 & .00411 & 197975001 & $\begin{array}{l}00336 \\
\text { and } \\
.0224\end{array}$ & $\begin{array}{l}.00411 \\
\text { and } \\
.0122\end{array}$ \\
\hline 5 & 1201495196 & 1663 & $\begin{array}{l}21- \\
\text { JAN- } \\
08\end{array}$ & .888 & .718 & .269 & .0178 & 200812001 & $\begin{array}{l}.036 \text { and } \\
.0434\end{array}$ & $\begin{array}{l}.0178 \\
\text { and } \\
.021\end{array}$ \\
\hline 6 & 1201478009 & 1645 & $\begin{array}{l}18- \\
\text { DEC- } \\
07\end{array}$ & .886 & .718 & .28 & .00539 & 199166001 & $\begin{array}{l}0 \text { and } \\
.00214\end{array}$ & $\begin{array}{l}.00539 \\
\text { and } \\
.00542\end{array}$ \\
\hline 7 & 1201343728 & 1655 & $\begin{array}{l}02- \\
\text { JUN- } \\
07\end{array}$ & .531 & 718 & .934 & .00871 & 186716001 & $\begin{array}{l}-.000575 \\
\text { and } \\
.0135\end{array}$ & $\begin{array}{l}.00871 \\
\text { and } \\
.0123\end{array}$ \\
\hline 8 & 1201349155 & 1678 & $\begin{array}{l}14- \\
\text { JUN- } \\
07\end{array}$ & .906 & .718 & .287 & .00501 & 187164001 & $\begin{array}{l}-.000413 \\
\text { and } \\
.00169\end{array}$ & $\begin{array}{l}.00501 \\
\text { and } \\
.00534\end{array}$ \\
\hline 9 & 1201347905 & 1659 & $\begin{array}{l}13- \\
\mathrm{JUN}- \\
07\end{array}$ & 1.04 & .718 & .843 & .0123 & 187075001 & $\begin{array}{l}-.00296 \\
\text { and } \\
.00985\end{array}$ & $\begin{array}{l}.0123 \\
\text { and } \\
.00893\end{array}$ \\
\hline 10 & 1201350786 & 1675 & $\begin{array}{l}15- \\
\mathrm{JUN}- \\
07\end{array}$ & .816 & .718 & 0 &, 00574 & 187371001 & 0 and 0 & $\begin{array}{l}.00574 \\
\text { and } \\
.0049 \\
\end{array}$ \\
\hline 11 & 1201358645 & 1660 & $\begin{array}{l}26- \\
0 U N- \\
07\end{array}$ & .93 & .718 & 117 & 241 & 188066001 & $\begin{array}{l}2.81 \text { and } \\
2.85\end{array}$ & $\begin{array}{l}.241 \\
\text { and } \\
.244 \\
\end{array}$ \\
\hline 12 & 1201360637 & 1689 & $\begin{array}{l}27- \\
\text { JUN- } \\
07\end{array}$ & .984 & .718 & .513 & .00493 & 188127001 & $\begin{array}{l}00195 \\
\text { and } \\
0104\end{array}$ & $\begin{array}{l}00493 \\
\text { and } \\
0104\end{array}$ \\
\hline 13 & 1201354257 & 1710 & $\left\{\begin{array}{l}21- \\
\pi N- \\
07\end{array}\right.$ & .775 & .718 & .628 & .0206 & 187443001 & $\begin{array}{l}.0377 \\
\text { and } \\
.0601\end{array}$ & $\begin{array}{l}.0206 \\
\text { and } \\
.0291\end{array}$ \\
\hline
\end{tabular}




\begin{tabular}{|c|c|c|c|c|c|c|c|c|c|c|}
\hline 14 & 1201374195 & 1697 & $\begin{array}{l}20- \\
\text { JUL- } \\
07\end{array}$ & 1.01 & .718 & 1.68 & .004721 & 189413001 & $\begin{array}{l}0 \text { and } \\
.0251\end{array}$ & $\begin{array}{l}.00472 \\
\text { and } \\
0142\end{array}$ \\
\hline 15 & 1201375657 & 1714 & $\begin{array}{l}24- \\
\text { JUL- } \\
07\end{array}$ & .903 & .718 & 1.77 & .0175 & 189593001 & $\begin{array}{l}.032 \text { and } \\
-.000298\end{array}$ & $\begin{array}{l}.0175 \\
\text { and } \\
.00503\end{array}$ \\
\hline 16 & 1201378049 & 1659 & $\begin{array}{l}25- \\
\text { JUL- } \\
07\end{array}$ & .396 & .718 & .225 & .242 & 189776001 & $\begin{array}{l}1.76 \text { and } \\
1.84\end{array}$ & $\begin{array}{l}242 \\
\text { and } \\
261\end{array}$ \\
\hline 17 & 1201379979 & 1647 & $\begin{array}{l}30- \\
3 \mathrm{UL} \\
07\end{array}$ & .939 & .718 & .598 & .0544 & 190038001 & .296 and & $\begin{array}{l}.0544 \\
\text { and } \\
.059\end{array}$ \\
\hline 18 & 1201387031 & 1673 & $\begin{array}{l}11- \\
\text { AUG- } \\
07\end{array}$ & .913 & .718 & .226 & .00509 & 190622002 & $\begin{array}{l}.00212 \\
\text { and - } \\
.0053\end{array}$ & $\begin{array}{l}.00509 \\
\text { and } \\
0131\end{array}$ \\
\hline 19 & 1201403903 & 1647 & $\begin{array}{l}06- \\
\text { SEP- } \\
07\end{array}$ & .955 & .718 & 1.48 & .00488 & 192440001 & $\begin{array}{l}-.0016 \\
\text { and } .017\end{array}$ & $\begin{array}{l}.00488 \\
\text { and } \\
.0116\end{array}$ \\
\hline 20 & 1201407285 & 1702 & $\begin{array}{l}08- \\
\text { SEP- } \\
07\end{array}$ & .705 & 718 & .271 & .00665 & 192741001 & and -.012 & $\begin{array}{l}00665 \\
\text { and } \\
.0378\end{array}$ \\
\hline 21 & 1201437507 & 1694 & $\begin{array}{l}07- \\
\text { Nov- } \\
07\end{array}$ & .542 & .718 & 1.01 & .0137 & 195471001 & $\mid 015$ and & $\begin{array}{l}.0137 \\
\text { and } \\
.0059\end{array}$ \\
\hline 22 & 1201440106 & 1698 & $\begin{array}{l}19- \\
\text { OCT- } \\
07\end{array}$ & .83 & .718 & 316 & 1.00604 & 195489001 & $\begin{array}{l}.00113 \\
\text { and - } \\
.00127\end{array}$ & $\begin{array}{l}.00604 \\
\text { and } \\
00459\end{array}$ \\
\hline 23 & 1201518608 & 1641 & $\begin{array}{l}27- \\
\text { FEB- } \\
08\end{array}$ & .241 & 718 & .519 & .0949 & 203019001 & $\begin{array}{l}-.0261 \\
\text { and } \\
.0261\end{array}$ & $\begin{array}{l}.0949 \\
\text { and } \\
.0336\end{array}$ \\
\hline
\end{tabular}

Plutonium-239/240

\begin{tabular}{|c|c|c|c|c|c|c|c|c|c|c|}
\hline \# & Sample W & Inst & $\begin{array}{l}\text { Run } \\
\text { Date }\end{array}$ & $\begin{array}{l}\text { Tracer } \\
\text { Yileld }\end{array}$ & Mean & RER & TPU & $\begin{array}{l}\text { Parent } \\
\text { Sample }\end{array}$ & Result & TPU \\
\hline 11 & 1201366796 & 1677 & $\begin{array}{l}09- \\
\text { JUL- } \\
07\end{array}$ & .974 & .703 & 228 & .0157 & 188743001 & $\begin{array}{l}.031 \\
\text { and } \\
.0359\end{array}$ & $\begin{array}{l}.0157 \\
\text { and } \\
0147\end{array}$ \\
\hline 2 & 1.201449897 & 1680 & $\begin{array}{l}07- \\
\text { Nov- } \\
07\end{array}$ & .933 & .703 & .063 & .0293 & 196602001 & $\begin{array}{l}.0934 \\
\text { and } \\
.096\end{array}$ & $\begin{array}{l}.0293 \\
\text { and } \\
.0291\end{array}$ \\
\hline
\end{tabular}




\begin{tabular}{|c|c|c|c|c|c|c|c|c|c|c|}
\hline 3 & 1201403073 & 1643 & $\begin{array}{l}04- \\
\text { SEP- } \\
07\end{array}$ & .685 & .703 & .0551 & .0318 & 192329001 & $\begin{array}{l}.0938 \\
\text { and } \\
.0963\end{array}$ & $\begin{array}{l}.0318 \\
\text { and } \\
.0324\end{array}$ \\
\hline 4 & 1201464618 & 1699 & $\begin{array}{l}13- \\
\text { DEC- } \\
07\end{array}$ & $\mid 1.01$ & .703 & 1.63 & 0997 & 197975001 & $\begin{array}{l}1.07 \\
\text { and } \\
.851\end{array}$ & $\begin{array}{l}.0997 \\
\text { and } \\
.0897\end{array}$ \\
\hline 5 & 1201495196 & 1663 & $\begin{array}{l}21- \\
\text { JAN- } \\
08 \\
\end{array}$ & .888 & 703 & 1.03 & .0616 & 200812001 & $\begin{array}{l}.356 \\
\text { and } \\
.272\end{array}$ & $\begin{array}{l}.0616 \\
\text { and } \\
.0537\end{array}$ \\
\hline 6 & 1201478009 & 1645 & \begin{tabular}{|l}
$18-$ \\
DEC- \\
07 \\
\end{tabular} & .886 & .703 & 1.1 & .0261 & 199166001 & $\begin{array}{l}-.0148 \\
\text { and } \\
.0159 \\
\end{array}$ & $\begin{array}{l}.0261 \\
\text { and } \\
0102\end{array}$ \\
\hline 7 & 1201343728 & 1655 & $\begin{array}{l}2- \\
\text { JUN- } \\
07 \\
\end{array}$ & .531 & .703 & .545 & .00809 & 186716001 & $\begin{array}{l}.00891 \\
\text { and } \\
.018\end{array}$ & $\begin{array}{l}00809 \\
\text { and } \\
.0146\end{array}$ \\
\hline 8 & 1201349155 & 1678 & \begin{tabular}{|l|}
$14-$ \\
JUN- \\
07
\end{tabular} & .906 & .703 & 2,14 & .0222 & 187164001 & $\begin{array}{l}.0583 \\
\text { and } \\
.00791\end{array}$ & $\begin{array}{l}.0222 \\
\text { and } \\
.00791\end{array}$ \\
\hline 9 & 1201347905 & 1659 & $\begin{array}{l}13- \\
\text { JUN- } \\
07\end{array}$ & 1.04 & .703 & .245 & .0231 & 187075001 & $\begin{array}{l}.0719 \\
\text { and } \\
.0809\end{array}$ & $\begin{array}{l}.0231 \\
\text { and } \\
0286 \\
\end{array}$ \\
\hline 10 & 1201350786 & 1675 & $\begin{array}{l}15- \\
\text { JN- } \\
07 \\
\end{array}$ & .816 & .703 & 1.22 & .00797 & 187371001 & $\begin{array}{l}.0141 \\
\text { and - } \\
.00266\end{array}$ & $\begin{array}{l}.00797 \\
\text { and } \\
.0049\end{array}$ \\
\hline 11 & 1201358645 & 1660 & $\begin{array}{l}26- \\
\text { JUN- } \\
07 \\
\end{array}$ & .93 & .703 & .935 & .019 & 188066001 & \begin{tabular}{|l|}
.0434 \\
and \\
.0723 \\
\end{tabular} & $\begin{array}{l}.019 \\
\text { and } \\
.0244 \\
\end{array}$ \\
\hline 12 & 1201360637 & 1689 & $\begin{array}{l}27- \\
\text { JUN- } \\
07 \\
\end{array}$ & .984 & .703 & .802 & .0129 & 188127001 & $\begin{array}{l}.0189 \\
\text { and } \\
.00906\end{array}$ & $\begin{array}{l}.0129 \\
\text { and } \\
.00737\end{array}$ \\
\hline 13 & 1201354257 & 1710 & $\begin{array}{l}21- \\
\text { JUN- } \\
07 \\
\end{array}$ & .775 & .703 & 815 & .0534 & 187443001 & $\begin{array}{l}248 \\
\text { and } \\
.319 \\
\end{array}$ & \begin{tabular}{|l|}
.0534 \\
and \\
0688
\end{tabular} \\
\hline 14 & 1201374195 & 1697 & $\begin{array}{l}20- \\
\text { JUL- } \\
07 \\
\end{array}$ & 1.01 & .703 & .228 & .013 & 189413001 & $\begin{array}{l}-.0104 \\
\text { and - } \\
.00724 \\
\end{array}$ & $\begin{array}{l}013 \\
\text { and } \\
00477\end{array}$ \\
\hline 15 & 1201375657 & 1714 & $\begin{array}{l}24- \\
\mathrm{jUL} \\
07\end{array}$ & .903 & .703 & 0 & .00509 & 189593001 & $\begin{array}{l}.00893 \\
\text { and - } \\
.00893 \\
\end{array}$ & $\begin{array}{l}.00509 \\
\text { and } \\
.00503\end{array}$ \\
\hline 16 & 1201378049 & 1659 & \begin{tabular}{|l|}
$25-$ \\
JUL- \\
07 \\
07
\end{tabular} & .396 & .703 & 317 & .0345 & 189776001 & $\begin{array}{l}0628 \\
\text { and } \\
.0481 \\
\end{array}$ & $\begin{array}{l}.0345 \\
\text { and } \\
.031 \\
\end{array}$ \\
\hline
\end{tabular}




\begin{tabular}{|c|c|c|c|c|c|c|c|c|c|c|}
\hline 17. & 1201379979 & 1647 & $\begin{array}{l}30- \\
\text { JUL- } \\
07\end{array}$ & .939 & .703 & .0109 & .00258 & 190038001 & $\begin{array}{l}-.00534 \\
\text { and - } \\
.0053\end{array}$ & $\begin{array}{l}.00258 \\
\text { and } \\
.00259\end{array}$ \\
\hline 18 & 1201387031 & 1673 & $\begin{array}{l}11- \\
\text { AUG- } \\
07\end{array}$ & .913 & .703 & .00735 & .00994 & 190622002 & $\begin{array}{l}-.016 \\
\text { and - } \\
.0159\end{array}$ & $\begin{array}{l}.00994 \\
\text { and } \\
.00928\end{array}$ \\
\hline 19 & 1201403903 & 1647 & $\begin{array}{l}06- \\
\text { SEP- } \\
07\end{array}$ & .955 & $.703^{\prime}$ & .578 & .00514 & 192440001 & $\begin{array}{l}-.0129 \\
\text { and - } \\
.00922\end{array}$ & $\begin{array}{l}.00514 \\
\text { and } \\
.00375\end{array}$ \\
\hline 20 & 1201407285 & 1702 & $\begin{array}{l}08- \\
\text { SEP- } \\
07\end{array}$ & .705 & .703 & 2.31 & .0106 & 192741001 & $\begin{array}{l}.0165 \\
\text { and - } \\
.0139\end{array}$ & $\begin{array}{l}0106 \\
\text { and } \\
.00779\end{array}$ \\
\hline 21 & 1201437507 & 1694 & $\begin{array}{l}07- \\
\text { NOV- } \\
07\end{array}$ & .542 & .703 & .0626 & .0237 & 195471001 & $\begin{array}{l}-.0153 \\
\text { and - } \\
0135\end{array}$ & $\begin{array}{l}0237 \\
\text { and } \\
0163\end{array}$ \\
\hline 22 & 1201440106 & 1698 & $\begin{array}{l}19- \\
\text { OCT- } \\
07\end{array}$ & .83 & .703 & 231 & .0158 & 195489001 & $\begin{array}{l}.0165 \\
\text { and - } \\
.0127\end{array}$ & $\begin{array}{l}0158 \\
\text { and } \\
00459\end{array}$ \\
\hline $23 \mid$ & 1201518608 & 1641 & $\begin{array}{l}27- \\
\text { FEB- } \\
08\end{array}$ & .241 & .703 & 1.62 & .141 & 203019001 & $\begin{array}{l}.496 \\
\text { and } \\
.228\end{array}$ & $\begin{array}{l}.141 \\
\text { and } \\
.0871\end{array}$ \\
\hline
\end{tabular}

Uranium-233/234

\begin{tabular}{|c|c|c|c|c|c|c|c|c|c|}
\hline$\#$ Sample ID & Inst & $\begin{array}{c}\text { Run } \\
\text { Date }\end{array}$ & $\begin{array}{c}\text { Tracer } \\
\text { Yteld }\end{array}$ & Mean & RER & TPU & $\begin{array}{c}\text { Parent } \\
\text { Sample }\end{array}$ & Result & TPU \\
\hline 1.1201440104 & 1587 & $18-$ & 865 & 1.82 & 1.82 & 19 & 195490001 & 1.87 and & 19 and \\
\hline
\end{tabular}

Uranium-235/236

\begin{tabular}{|c|c|c|c|c|c|c|c|c|c|}
\hline I Sample ID & Inst & $\begin{array}{l}\text { Run } \\
\text { Date }\end{array}$ & $\begin{array}{l}\text { Tracer } \\
\text { Yield }\end{array}$ & Mean & RER & TPU & $\begin{array}{l}\text { Parent } \\
\text { Sample }\end{array}$ & Result & TPU \\
\hline $1 \quad 1201440104$ & 1587 & $\begin{array}{l}18- \\
\text { OCT- } \\
07\end{array}$ & .865 & 1.47 & 1.47 & .0365 & 195490001 & $\begin{array}{l}.0935 \\
\text { and } \\
.0303\end{array}$ & $\begin{array}{l}.0365 \\
\text { and } \\
.0225\end{array}$ \\
\hline
\end{tabular}




\begin{tabular}{|c|c|c|c|c|c|c|c|c|c|c|}
\hline \multicolumn{11}{|c|}{ Uranium-238 } \\
\hline \# & Sample ID & Inst & $\begin{array}{l}\text { Run } \\
\text { Date }\end{array}$ & $\begin{array}{l}\text { Tracer } \\
\text { Yield }\end{array}$ & Mean & RER & TPU & $\begin{array}{l}\text { Parent } \\
\text { Sample }\end{array}$ & Result & TPU \\
\hline 1 & 1201440104 & 1587 & $\begin{array}{l}18- \\
\text { OCT- } \\
07\end{array}$ & .865 & .0374 & .0374 & 182 & 195490001 & $\begin{array}{l}1.8 \text { and } \\
1.79\end{array}$ & $\begin{array}{l}182 \\
\text { and } \\
.196\end{array}$ \\
\hline
\end{tabular}

\section{Sample Summary}

Overall, the chemical yields for the analytical processes were greater than the minimum yields required in the SOW. Those not meeting the yield requirements are further discussed in the Observation section of this report.

\section{OBSERVATIONS}

\section{Am Isotopic in Urine}

Out of thirty-nine high range Americium-243 LCSs, two (5.13\%) are less than $75 \%$, and one is greater than $125 \%$.

Out of seventeen low range Americium-243 LCSs, two (11.76\%) are less than $75 \%$, and six $(35.29 \%)$ are greater than $125 \%$.

Out of one hundred and fjfty-seven high range Americium-241 LCSs, seven (4.46\%) are greater than $125 \%$.

Out of one hundred and forty-six low range Americium-241 LCSs, twelve (8.22\%) are less than $75 \%$. Forty-five $(30.82 \%)$ are greater than $125 \%$.

Out of one thousand two hundred and fifty-nine Americium-243 yields, five $(0.40 \%)$ are less than the low yield of $40 \%$.

\section{Cm Isotopic in Urine}

Out of thirty low range Curium-243/244 LCSs, thirteen (43.33\%) are greater than $125 \%$. Two $(6.67 \%)$ are less than $75 \%$.

Out of one hundred and seventy-three Curium-243/244 yields, one $(0.58 \%)$ is less than the low yield of $40 \%$.

\section{Pu Isotopic in Urine}

Out of four hundred and thirty-two Pu-239/240 blanks, one (0.23\%) result is greater than the CL. This anomaly is documented by NCR 470608 . 
Out of four hundred and fifty-four high range Plutonium 239/240 LCSs, three $(0.66 \%)$ are less than $75 \%$.

Out of three hundred and seventy-eight low range Plutonium 239/240 LCSs, fifty-nine $(15.6 \%)$ are less than $75 \%$. Sixty-three $(16.67 \%)$ are greater than $125 \%$.

Out of the four thousand and eleven Pu-242 tracers, eighty-three (2.07\%) were less than the low yield of $50 \%$.

\section{Sr-90/Total Sr in Urine}

Out of one hundred twenty-three low range Strontium-90 LCSs, five (4.07\%) are less than $75 \%$, and three $(2.44 \%)$ are greater than $125 \%$.

Out of one hundred and thirty-three high range Strontium-90 LCSs, one $(0.75 \%)$ is less than $75 \%$, and one $(0.75 \%)$ is greater than $125 \%$.

Out of one thousand one hundred and eight-two Strontium carriers, seventeen $(1.44 \%)$ are less than the low yield of $50 \%$.

Out of ninety-nine Total Strontium yields, three (3.03\%) are less than the low yield of $50 \%$.

Out of twenty low range Total Strontium LCSs, two (10\%) are less than $125 \%$.

\section{Th Isotopic in Urine}

The Th-232 high and low LCS graphs showed no variation due to there being only one data point.

\section{Total Uranium in Urine}

Out of the ninety low range Total U LCSs, thirteen (14.44\%) were less than $75 \%$ and five $(5.56 \%)$ were greater than $125 \%$.

Out of ninety-seven high range Total Strontium LCSs, four (4.12\%) are less than $75 \%$, and one $(1.03 \%)$ is greater than $125 \%$.

\section{Tritium}

There are no observations for Tritium. 


\section{Uranium Isotopic in Urine}

Out of seven hundred and seventy-two Uranium-232 yields, fourteen $(1.81 \%)$ are less than $40 \%$, and one $(0.13 \%)$ is greater than $125 \%$.

Out of eighty-two Uranium-238 high range LCSs, one (1.22\%) is less than $75 \%$, and one $(1.22 \%)$ is greater then $125 \%$.

Out of seventy-eight low range Uranium-238 LCSs, six (7.69\%) are less than $75 \%$, and five $(6.41 \%)$ are greater than $125 \%$.

The Uranium-236 MB and LCS graphs show no variation due to there being only 1 data point.

Out of three Uranium-236 tracer yields, one (33.3\%) is greater than $125 \%$.

\section{Isotopic Am in Feces}

Out of twenty-one low range Americium-241 LCSs, six (28.6\%) are greater than $125 \%$.

Out of one hundred forty-four Americium-243 tracers, two (1.39\%) are less than the low yield of $50 \%$.

\section{Isotopic Pu in Feces}

Out of the thirty-one low range Plutonium-239/240 LCSs, one (3.23\%) was greater than $125 \%$.

Out of two hundred and seven Plutonium-242 tracer yields, ten $(4.83 \%)$ are below the low yield of $50 \%$. One $(0.48 \%)$ is below the minimum yield of $25 \%$. However the sample is a duplicate where the RER requirement was met, so the low recovery yield does not seem to have affected the analysis. Also, the requirement of one duplicate for every seven samples has been exceeded. Therefore, the results were reported.

\section{Isotopic $U$ in Feces}

The MDAs for Uranium-233/234 is greater than the CL of $0.02 \mathrm{dpm} / \mathrm{sample}$ due to elevated background levels; however, the U-235 MDA is below the CL.

Out of ten Uranium-232 tracer yields, one (10\%) is below the low yield requirement of $50 \%$.

The Uranium-233/234, Uranium-235/236, and Uranium-238 RER graph showed no variation due to there being only one dats point.

Out of the two Uranium-238 low LCSs, one (50\%) is greater than $125 \%$. 


\section{Incident Reports}

Incident Report for the inability to report Americium results for Tagwords 07B0518, 07B0522, 07B0526, 07B0528, 07B0557, 07B0558, 07B0561, 07B0565, 07B0567, and 07B0569 was submitted on April 6, 2007. The incident involved the inability to produce acceptable Americium tracer yields and was isolated to the technician. The analyses of the back-up samples were ordered and results were reported. Since the incident, the technician has been replaced with a newly trained analyst.

Incident Report for the inability to report Americium and Plutonium results for Tagword $07 \mathrm{E} 0520$ was submitted on June 11,2007 . This incident involved the cracking of a beaker and sample loss. The analysis of the back-up sample was ordered and results were reported.

Incident Report for the Americium error associated with work order 190378, August 27, 2007. The incident had no identifiable cause, so corrective action prevent the recurrence was not taken.

Incident Report for the Plutonium tracing error associated with work order 192606 , September 18, 2007. The incident involved an experienced analyst along with a witness to the spiking and tracing of the samples. The exact cause is still unknown; however, the fact the samples were not traced with Pu-242 has been established. Since there was a witness and the tracing error was isolated to one batch, no corrective action was taken.

Incident Report for the Strontium error associated with work order 195914, October 23 , 2007. The incident had occurred when the lab technician did not save the cluant while doing the column chemistry. Since this was done inadvertently, an incident report was created and no corrective action was necessary.

Incident Report for Tagword 07J0343 associated with work order 196484, November 5, 2007. The incident involved a laboratory technician forgetting to properly record a samples volume. An incident report was created and no further action was taken.

Incident Report for Tagwords 07K0317 and 07K0334 associated with work order 197610, November 13,2007. This incident involved the receipt of two leaking samples. The loss was less than $10 \%$, so an incident report was created. To resolve the issue, the RSC discussed how to properly tighten lids and purchased a different brand of tape to seal the container. No further action was taken. 
Incident Report for Tagwords $07 \mathrm{~K} 0154$ and $07 \mathrm{~K} 0121$ associated with work order 197626, November 15, 2007. This incident involved the combining of two separate samples. An incident report was created, and no further action was taken.

Incident Report for work order 201548, February 12, 2008. The incident involved results that were received by the client that did not match the data sent by EDD. The problem seemed to be a conversion error between the reports. The results in the original EDD were reported in $\mathrm{pCi} / \mathrm{mL}$ while the report units were in $\mathrm{dpm} / \mathrm{mL}$. The reason for this could not be determined. An incident report was created, and no further action was taken.

Incident Report for Tagwords 08B0150 and 08B0337, March 5, 2008. The incident involved the analyst accidentally knocking over the QC blank and LCS during the final filtering of the samples. We were able to count the samples and report with a FA qualifier, but the Quality Control samples did not exist. To resolve this incident the Group Leader of the Bioassay laboratory discussed the error with the employee, Technician, Benjamin Finley, and no further action was taken.

Incident Report for Tagwords 08A0058, 08A0121, 08A0149, 08A0168, 08A0186, 08A0202, 08A0238, 08A0245, 08A0286, and 08A0358, March 12, 2008. The incident involved a failed acceptance of a number of records that rejected in the electronic data deliverable (EDD). For each tagword the first line was rejected, and the second line showed in REX. Only the tritium results in the file were wrong. The problem was investigated. The data reported in the EDD sent to the client was in the units of $\mathrm{pci} / \mathrm{ml}$. The client required dpm/mL. Review of any possible audit changes to data, required units, client setup specifications, and EDD changes were evaluated, all with negative results. The problem was not reproducible with several re-runs of this work order through the EDD code. An incident report was created and no further action was taken.

Incident Report for Tagwords 08B0221, March 19, 2008. The incident involved a failed analysis for Am-243 due to laboratory error. Technician Tina Schoneman inadvertently poured a rinse from another sample, which had used Am-243 added as a tracer, onto $08 \mathrm{~B} 0221$. This error was identified by the technician at the time of the prep, and the count room was cautioned to verify the presence of Am-243. Upon completion of the analysis of 08B0221, the result showed Am-243 activity which we suspect is due to the aforementioned analytical error. No sample remained for a reanalysis. To resolve this issue, the Group Leader of the Bioassay laboratory discussed the error with the employee and no further action was taken. 
Incident Report for Tagwords 08C0214/08C 0215 and 08C0211/08C0212, March 24, 2008. The incident involved the mislabeling of kits that were delivered with bottles labeled for another person. The kit box for multiple analysis Tagwords $08 \mathrm{C} 0214 / 08 \mathrm{C} 0215$ was labeled properly on the outside, but the bottles were labeled for the person who was to receive a kit for Tagwords 08C0211/08C0212. Due to this confusion, both kits were replaced, and any samples collected in the original kits were discarded. The root cause of this error was established as inattention to detail. The incident was resolved when the incorrectly labeled kit for 08C0214/08C0215 was replaced with a correctly labeled kit. The other kit in question was canceled as per PNNL request and PNNL was putting on new tagwords to be delivered in the future. To resolve this incident the Group Leader of the Richland Service Center, Pete Wilber, has discussed the error with Wendy Mitchell, Courier who was responsible for preparing the kits. Attention to detail has been stressed. No further action was taken.

Incident Report for Tagwords 08C0462, April 11, 2008. The incident involved the wet ashing step of the preparatory process. The technician, Ben Finley, accidentally broke the glass vial holding the sample. The entire sample spilled onto the counter top and absorbent and the sample was lost. There is no sample available for re-prep. To resolve the issue the Group Leader of the Bioassay laboratory discussed the error with the employee and no further action was taken.

\section{Corrective Actions}

There are no corrective actions at this time. 


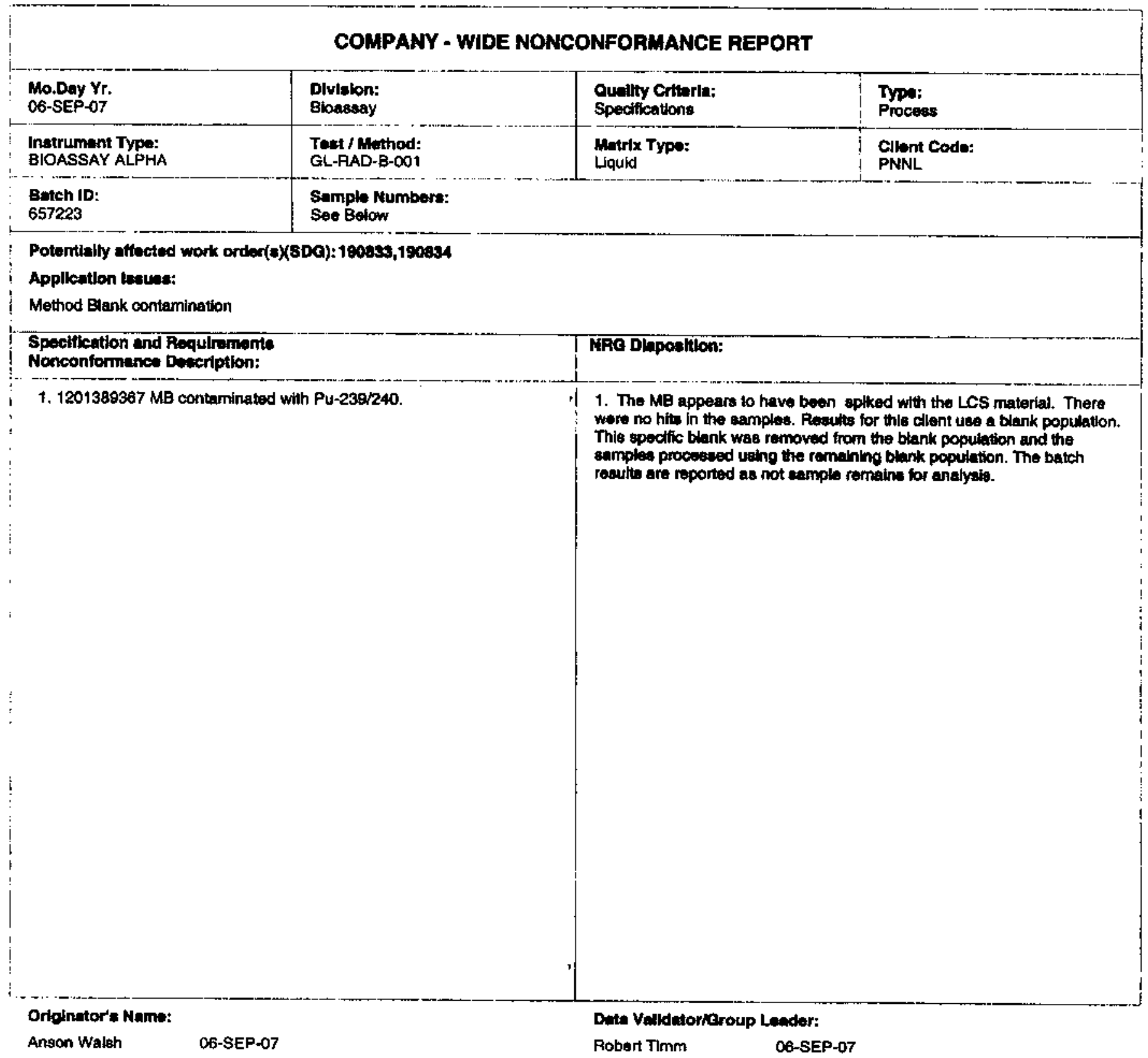

Quatity Revlow:

Director: 
APPENDIX C

GEL Duplicates

(Historical File Only) 


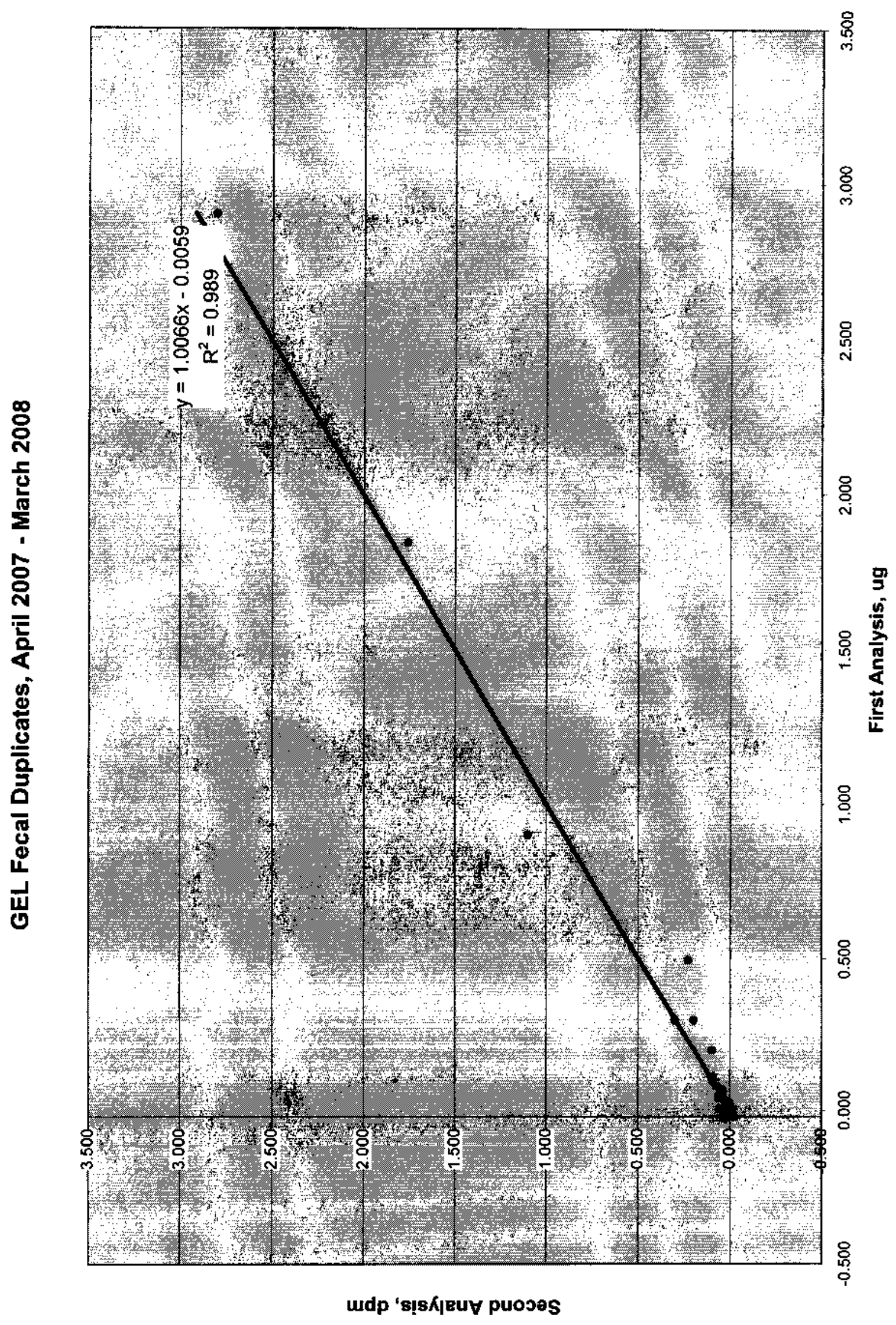




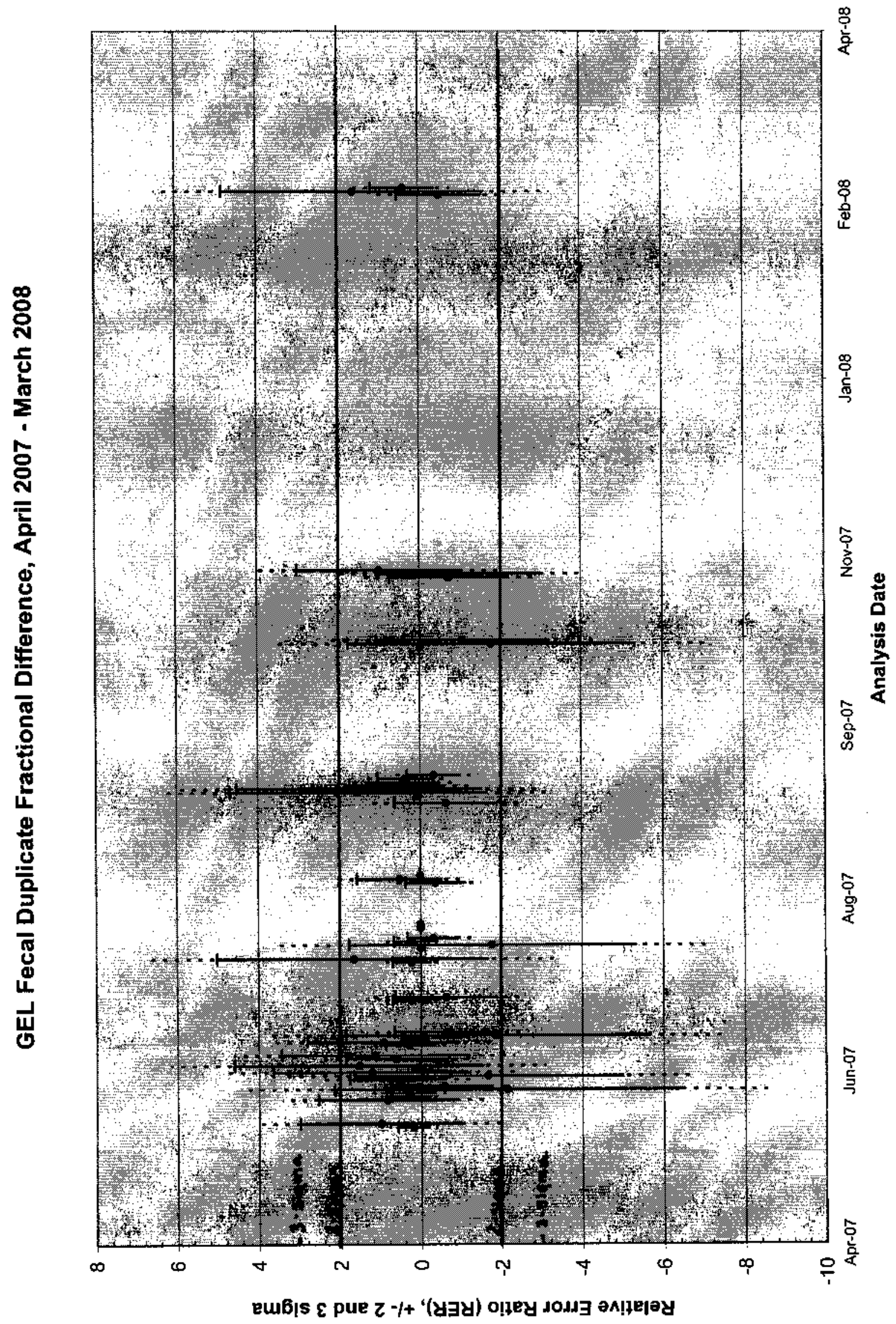


APPENDIX D

QUALITY CONTROL INTERCOMPARISON PARTICIPATION

RESULTS

(Historical File Only) 


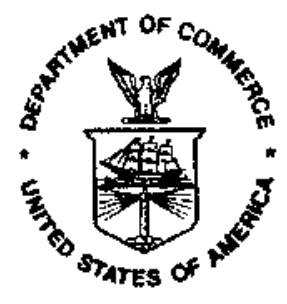

Test Identification:

Test Radionuclides:

Matrix Description:

Test Activity Range:

Reference Time:

U.S. DEPARTMENT OF COMMERCE

National institute of Standards and Technology

Gaithersburg, MD

\section{REPORT OF TRACEABILITY}

\section{General Engineering Laboratories, LLC Charleston, South Caroline}

NRIP-07-SU

${ }^{241} \mathrm{Am}^{243} \mathrm{Cm},{ }^{241} \mathrm{Am},{ }^{240} \mathrm{Pu},{ }^{238} \mathrm{Pu},{ }^{238} \mathrm{U},{ }^{235} \mathrm{U},{ }^{234} \mathrm{U},{ }^{230} \mathrm{Th},{ }^{226} \mathrm{Ra},{ }^{210} \mathrm{~Pb}$,

$2110 \mathrm{Po},{ }^{137} \mathrm{Cs},{ }^{50} \mathrm{Sr},{ }^{60} \mathrm{Co},{ }^{57} \mathrm{Co}$

Synthetic Urine

$30 \mathrm{mBq}$ sample ${ }^{-1}$ to $300 \mathrm{mBq} \cdot \mathrm{mample}^{-1}$

12:00 EST, April 1, 2007

Measurement Results

\begin{tabular}{|c|c|c|c|c|c|}
\hline \multirow[t]{2}{*}{ Nuclide } & \multicolumn{2}{|c|}{ NIST Value ${ }^{2+1}$} & \multicolumn{2}{|c|}{ Reported Value } & \multirow{2}{*}{$\begin{array}{l}\text { Difference }^{5} \\
( \pm \% \text { Bias })\end{array}$} \\
\hline & $\begin{array}{c}\text { Massic Activity } \\
\mathrm{Bq}^{-\mathrm{g}^{-1}}\end{array}$ & $\begin{array}{c}\text { Relative Expanded } \\
\text { Uncertainty }(\%, \mathrm{k}=2)\end{array}$ & $\begin{array}{c}\text { Massic Activity } \\
\mathrm{Bg}^{-1} \mathrm{~g}^{-1}\end{array}$ & $\begin{array}{c}\text { Relative Expanded } \\
\text { Uncertainty }(\%, \mathrm{k}=2)\end{array}$ & \\
\hline${ }^{211} \mathrm{Am}$ & 2.621 & 0.80 & 2.438 & 10.4 & -7.0 \\
\hline${ }^{240} \mathrm{Pu}$ & 1.112 & 0.76 & 1.050 & 11.2 & -5.6 \\
\hline${ }^{235} \mathbf{P u}$ & 0.901 & 0.68 & 0.860 & 11.6 & -4.6 \\
\hline${ }^{2.18} \mathrm{U}$ & 2.954 & 0.60 & 2.770 & 10.7 & -6.2 \\
\hline${ }^{234} \mathrm{U}$ & 2.846 & 0.98 & 2.706 & 10.7 & -4.9 \\
\hline${ }^{235} \mathrm{U}$ & 0.136 & 0.62 & 0.136 & 26.2 & -0.1 \\
\hline${ }^{230} \mathrm{Th}$ & 1.348 & 0.58 & 1.276 & 12.0 & -5.4 \\
\hline${ }^{226} \mathbf{R a}$ & 2.277 & 0.89 & 1.9 & 33.7 & -16 \\
\hline${ }^{210} \mathbf{P o}$ & 11.18 & 3.2 & 10.52 & 10.7 & -5.9 \\
\hline${ }^{137} \mathrm{Cs}$ & 516.9 & 0.68 & 533.2 & 10.4 & 3.1 \\
\hline${ }^{91} \mathrm{Sr}$ & 25.13 & 0.74 & 24.50 & 11.8 & -2.4 \\
\hline${ }^{60} \mathrm{Co}$ & 661.0 & 0.74 & 672.8 & 10.2 & 1.8 \\
\hline${ }^{57} \mathrm{Co}$ & 855.1 & 3.7 & 839.0 & 10.3 & -1.9 \\
\hline \multicolumn{6}{|c|}{ Methods } \\
\hline \multirow{2}{*}{\multicolumn{2}{|c|}{ Activity Measurements }} & \multicolumn{2}{|c|}{ NIST $^{5}$} & \multicolumn{2}{|c|}{ Reporting Laboratory } \\
\hline & & \multicolumn{2}{|c|}{$\begin{array}{c}\text { Alpha- and Be1a-Spectrometry } \\
\text { Mass Spectronetry }\end{array}$} & \multicolumn{2}{|c|}{ Alpha. Beta, and Gamma Spectrometry } \\
\hline
\end{tabular}

Evaluation (per ANSI N42.22 and N13.30)

\begin{tabular}{|c|c|c|c|c|}
\hline \multirow[t]{3}{*}{ Nuclide } & \multicolumn{2}{|c|}{$\mathrm{N} \$ 2.22^{\mathrm{B}}$} & \multirow{2}{*}{\multicolumn{2}{|c|}{$\begin{array}{c}\text { N13.30 } \\
\text { Results Acceptable per N13.30 Criteria } \\
\text { (Pass/Fail) }\end{array}$}} \\
\hline & \multirow[t]{2}{*}{$\begin{array}{c}\text { ANSI N42.22 } \\
\text { Truceable }\end{array}$} & \multirow{2}{*}{$\begin{array}{l}\text { Traceability } \\
\text { Limit } \\
\text { (t)Percent) }\end{array}$} & & \\
\hline & & & Bias & Precision \\
\hline $\begin{array}{c}{ }^{244} \mathrm{Am} \\
{ }^{140} \mathrm{Pu} \\
{ }^{2.14} \mathrm{Pu} \\
{ }^{238} \mathrm{U} \\
{ }^{236} \mathrm{U} \\
{ }^{23.15} \mathrm{U} \\
{ }^{230} \mathrm{Th} \\
{ }^{226} \mathrm{Ra} \\
{ }^{216} \mathrm{Po} \\
{ }^{1.37} \mathrm{Cs} \\
{ }^{90} \mathrm{Sr} \\
{ }^{60} \mathrm{Co} \\
{ }^{57} \mathrm{Co}\end{array}$ & $\begin{array}{l}\text { Yes } \\
\text { Yes } \\
\text { Yes } \\
\text { Yes } \\
\text { Yes } \\
\text { Yes } \\
\text { Yes } \\
\text { Yes } \\
\text { Yes } \\
\text { Yes } \\
\text { Yes } \\
\text { Yes } \\
\text { Yes }\end{array}$ & $\begin{array}{l}15 \\
16 \\
17 \\
15 \\
15 \\
39 \\
17 \\
42 \\
16 \\
16 \\
17 \\
16 \\
27\end{array}$ & $\begin{array}{l}\text { Pass } \\
\text { Pass } \\
\text { Pass } \\
\text { Pass } \\
\text { Pass } \\
\text { Pass } \\
\text { Pass } \\
\text { Pass } \\
\text { Pass } \\
\text { Pass } \\
\text { Pass } \\
\text { Pass } \\
\text { Pass }\end{array}$ & $\begin{array}{l}\text { Pass } \\
\text { Pass } \\
\text { Pass } \\
\text { Pass } \\
\text { Pass } \\
\text { Pass } \\
\text { Pass } \\
\text { Pass } \\
\text { Pass } \\
\text { Pass } \\
\text { Pass } \\
\text { Pass } \\
\text { Pass }\end{array}$ \\
\hline
\end{tabular}

Samples Distributed

October 1, 2007

Reporting Data Keceived December 4, 2007
For the Dinector

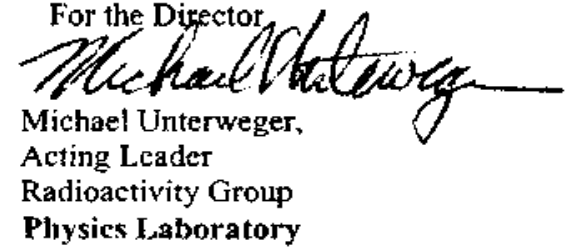

(Continued) 


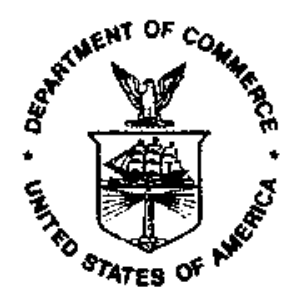

Test Identification:

Test Radionuclides:

Matrix Description:

Test Activity Range:

Reference Time:
U.S. DEPARTMENT OF COMMERCE

National Institute of Standards and Technology

Gathersburg, MD

\section{REPORT OF TRACEABILITY}

\section{General Engineering Laboratories, LLC Charleston, South Caroline}

NRIP-07-SU

${ }^{243} \mathrm{Cm},{ }^{241} \mathrm{Am},{ }^{240} \mathrm{Pu}_{4}{ }^{238} \mathrm{Pu}_{, 4}{ }^{238} \mathrm{U},{ }^{235} \mathrm{U},{ }^{234} \mathrm{U},{ }^{230} \mathrm{Tlt},{ }^{226} \mathrm{Ra},{ }^{210} \mathrm{~Pb}$.

${ }^{210} \mathrm{Po},{ }^{137} \mathrm{Cs},{ }^{30} \mathrm{Sr},{ }^{60} \mathrm{Co},{ }^{57} \mathrm{Co}$

Synthetic Uirine

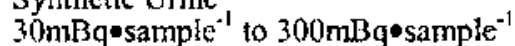

12:00 EST, April 1, 2007

Measurement Results

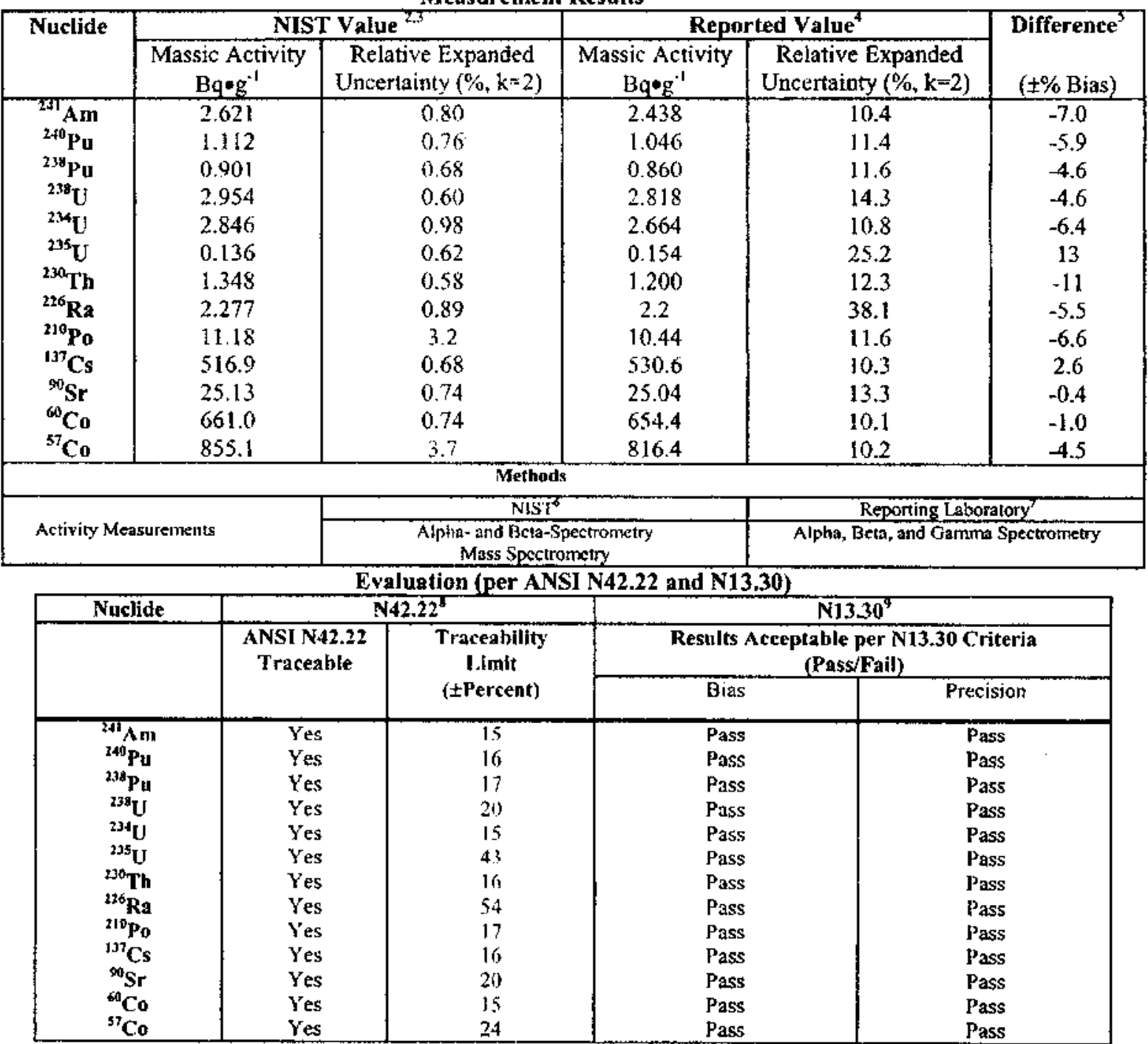

Samples Distributed

October 1, 2007

Reporting Data Received December 4, 2007
For the Director

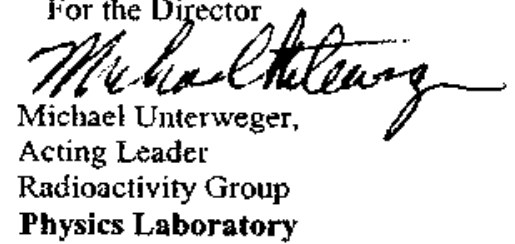

(Continued) 


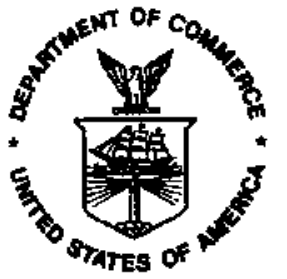

Test Identification: Test Radionuclides:

Matrix Description:

Test Activity Range: Reference Time:
U.S. DEPARTMENT OF COMMERCE

National Institute of Standards and Technology

Gaithersburg, MD

\section{REPORT OF TRACEABILITY}

\section{General Engineering Laboratories, LLC Charleston, South Caroline}

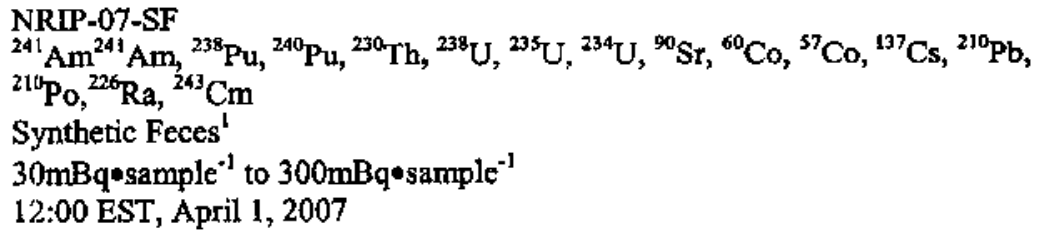

Measurement Results

\begin{tabular}{|c|c|c|c|c|c|}
\hline \multirow[t]{2}{*}{ Nuclide } & \multicolumn{2}{|c|}{ NIST Value ${ }^{2,3}$} & \multicolumn{2}{|c|}{ Reported Value } & \multirow{2}{*}{$\begin{array}{l}\text { Difference }^{5} \\
\text { (士\% Bias) }\end{array}$} \\
\hline & $\begin{array}{c}\text { Massic Activity } \\
\text { Bq }^{-1}\end{array}$ & $\begin{array}{c}\text { Relative Expanded } \\
\text { Uncertainty }(\%, k=2)\end{array}$ & $\begin{array}{l}\text { Massic Activity } \\
\text { Bq }^{-1}\end{array}$ & $\begin{array}{c}\text { Relative Expanded } \\
\text { Uncertainty }(\%, k=2)\end{array}$ & \\
\hline${ }^{241} \mathbf{A m}$ & 2.479 & 0.80 & 2.334 & 14.1 & -5.8 \\
\hline${ }^{238} \mathbf{P u}$ & 0.851 & 0.68 & 0.761 & 11.7 & -11 \\
\hline${ }^{240} \mathrm{Pu}$ & 1.052 & 0.76 & 0.962 & 11.3 & -8.5 \\
\hline${ }^{230} \mathrm{~Tb}$ & 1.275 & 0.68 & 1.292 & 11.7 & 1.3 \\
\hline${ }^{238} \mathbf{U}$ & 2.795 & 0.76 & 2.656 & 10.7 & -5.0 \\
\hline${ }^{234} \mathrm{U}$ & 2.692 & 0.80 & 2.508 & 10.9 & -6.8 \\
\hline${ }^{n 5} \mathrm{U}$ & 0.129 & 0.74 & 0.144 & 25.3 & 12 \\
\hline${ }^{90} \mathrm{Sr}$ & 23.69 & 0.68 & 23.14 & 10.3 & -2.3 \\
\hline \multicolumn{3}{|c|}{ NR= Not Reported } & & \multicolumn{2}{|c|}{ NA= Not Applleable } \\
\hline \multicolumn{6}{|c|}{ Methods } \\
\hline \multirow{2}{*}{\multicolumn{2}{|c|}{ Activity Measurements }} & \multicolumn{2}{|c|}{$\mathrm{NIST}^{\mathrm{s}}$} & \multicolumn{2}{|c|}{ Reporting Laboratory } \\
\hline & & \multicolumn{2}{|c|}{$\begin{array}{l}\text { Alpha- and Beta-Spectrometry } \\
\text { Mass Spectrometry }\end{array}$} & \multicolumn{2}{|c|}{ Alpha, Beta, and Gamme Spectrometry } \\
\hline
\end{tabular}

Evaluation (per ANSI N42.22 and N13.30)

\begin{tabular}{|c|c|c|c|c|}
\hline \multirow[t]{3}{*}{ Nuclide } & \multicolumn{2}{|c|}{$\mathrm{N} 42.22^{\circ}$} & \multirow{2}{*}{\multicolumn{2}{|c|}{$\begin{array}{c}\text { N13.30 } \\
\text { Results Acceptable per N13.30 Criteria } \\
\text { (Pass/Fail) }\end{array}$}} \\
\hline & \multirow[t]{2}{*}{$\begin{array}{c}\text { ANSI N42.22 } \\
\text { Traceable }\end{array}$} & \multirow{2}{*}{$\begin{array}{l}\text { Traceability } \\
\text { Limit } \\
\text { ( } \pm \text { Percent) }\end{array}$} & & \\
\hline & & & Bias & Precision \\
\hline 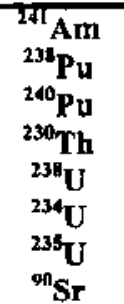 & $\begin{array}{l}\text { Yes } \\
\text { Yes } \\
\text { Yes } \\
\text { Yes } \\
\text { Yes } \\
\text { Yes } \\
\text { Yes } \\
\text { Yes }\end{array}$ & $\begin{array}{l}20 \\
16 \\
16 \\
18 \\
15 \\
15 \\
42 \\
15\end{array}$ & $\begin{array}{l}\text { Pass } \\
\text { Pass } \\
\text { Pass } \\
\text { Pass } \\
\text { Pass } \\
\text { Pass } \\
\text { Pass } \\
\text { Pass }\end{array}$ & $\begin{array}{l}\text { Pass } \\
\text { Pass } \\
\text { Pass } \\
\text { Pass } \\
\text { Pass } \\
\text { Pass } \\
\text { Pass } \\
\text { Pass }\end{array}$ \\
\hline
\end{tabular}

Samples Distributed

May 10,2007

Reporting Data Received
July 12,2007

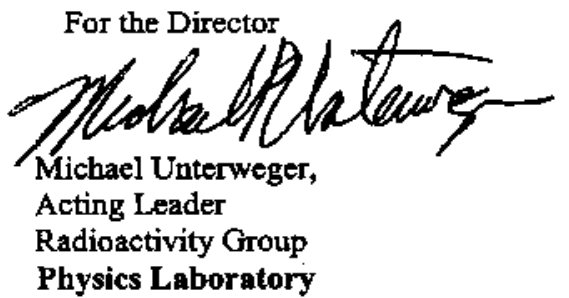

(Continued) 


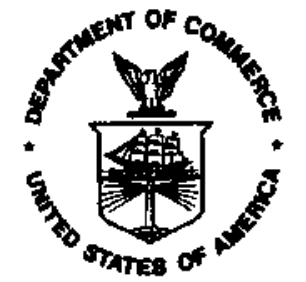

Test Identification:

Test Radionuclides:

Matrix Description:

Test Activity Range:

Reference Time:
U.S. DEPARTMENT OF COMMERCE

National Institute of Standards and Technology

Gaithersburg, MD

\section{REPORT OF TRACEABILITY}

\section{General Engineering Laboratories, LLC Charleston, South Caroline}

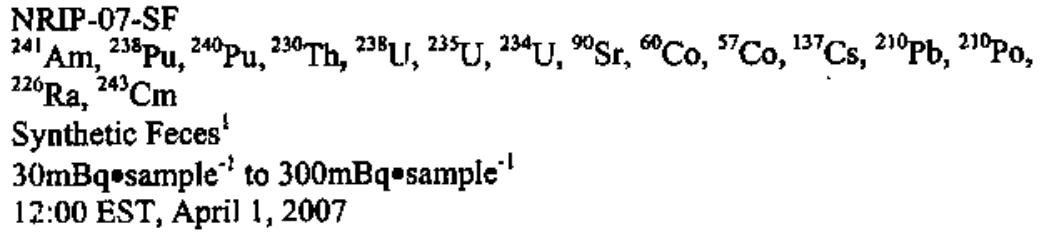

NRIP-07-SF

${ }^{241} \mathrm{Am},{ }^{238} \mathrm{Pu},{ }^{240} \mathrm{Pu},{ }^{230} \mathrm{Th},{ }^{238} \mathrm{U},{ }^{235} \mathrm{U},{ }^{234} \mathrm{U},{ }^{90} \mathrm{Sr},{ }^{60} \mathrm{Co},{ }^{57} \mathrm{Co},{ }^{137} \mathrm{Cs},{ }^{210} \mathrm{~Pb},{ }^{210} \mathrm{Po}$,

$30 \mathrm{mBq} \cdot$ sample $^{-2}$ to $300 \mathrm{mBq} \cdot \mathrm{sampl}^{-1}$

12:00 EST, April 1, 2007

Measurement Results

\begin{tabular}{|c|c|c|c|c|c|}
\hline \multirow[t]{2}{*}{ Nuclide } & \multicolumn{2}{|c|}{ NIST Value 2,3} & \multicolumn{2}{|c|}{ Reported Value } & \multirow{2}{*}{$\begin{array}{l}\text { Difference }^{3} \\
\text { ( } \pm \% \text { Bias) }\end{array}$} \\
\hline & $\begin{array}{c}\text { Massic Activity } \\
\mathrm{Bq}^{\circ \mathrm{g}^{-1}}\end{array}$ & $\begin{array}{c}\text { Relative Expanded } \\
\text { Uncertainty }(\%, \mathrm{k}=2)\end{array}$ & $\begin{array}{c}\text { Massic Activity } \\
\text { Bq }^{-1}\end{array}$ & $\begin{array}{c}\text { Relative Expanded } \\
\text { Uncertainty }(\%, k=2)\end{array}$ & \\
\hline${ }^{2 \pi t} \mathrm{Am}$ & 2.479 & 0.80 & 2.318 & 15.2 & -6.5 \\
\hline${ }^{239} \mathrm{Pu}$ & 0.851 & 0.68 & 0.796 & 16.0 & -6.5 \\
\hline${ }^{240} \mathbf{P u}$ & 1.052 & 0.76 & 0.991 & 11.7 & -5.8 \\
\hline${ }^{230} \mathrm{Th}$ & 1.275 & 0.68 & 1.232 & 23.1 & -3.4 \\
\hline${ }^{218} \mathrm{U}$ & 2.795 & 0.76 & 2.666 & 11.6 & -4.6 \\
\hline${ }^{234} \mathrm{U}$ & 2.692 & 0.80 & 2.514 & 10.9 & -6.6 \\
\hline${ }^{235} \mathrm{U}$ & 0.129 & 0.74 & 0.137 & 25.6 & 6.5 \\
\hline${ }^{90} \mathrm{Sr}$ & 23.69 & 0.68 & 24.06 & 10.4 & 1.5 \\
\hline \multicolumn{6}{|c|}{ NR- Not Reported } \\
\hline \multicolumn{6}{|c|}{ Methods } \\
\hline \multirow{2}{*}{\multicolumn{2}{|c|}{ Activity Meastrements }} & \multicolumn{2}{|c|}{$\mathrm{NIST}^{6}$} & \multicolumn{2}{|c|}{ Reporting Laborntory' } \\
\hline & & \multicolumn{2}{|c|}{$\begin{array}{l}\text { Alpha- and Beta-Spectrometry } \\
\text { Mass Spectrometry }\end{array}$} & \multicolumn{2}{|c|}{ Alpha, Beta, and Gamma Spectrometry } \\
\hline
\end{tabular}

Evaluation (per ANSI N42.22 and N13.30)

\begin{tabular}{|c|c|c|c|c|}
\hline \multirow[t]{3}{*}{ Nuclide } & \multicolumn{2}{|c|}{ N42.22 } & \multirow{2}{*}{\multicolumn{2}{|c|}{$\begin{array}{c}\text { N13.30 } \\
\text { Results Acceptable per N13.30 Criterig } \\
\text { (Pass/Fail) }\end{array}$}} \\
\hline & \multirow[t]{2}{*}{$\begin{array}{c}\text { ANSI N42.22 } \\
\text { Traceable }\end{array}$} & \multirow{2}{*}{$\begin{array}{l}\text { Traceability } \\
\text { Limit } \\
\text { ( } \pm \text { Percent) }\end{array}$} & & \\
\hline & & & Bias & Precision \\
\hline $\begin{array}{l}{ }^{241} \mathrm{Am} \\
{ }^{238} \mathrm{Pu} \\
{ }^{240} \mathrm{Pu} \\
{ }^{230} \mathrm{Th} \\
{ }^{238} \mathrm{U} \\
{ }^{234} \mathrm{U} \\
{ }^{235} \mathrm{U} \\
{ }^{90} \mathrm{Sr}\end{array}$ & $\begin{array}{l}\text { Yes } \\
\text { Yes } \\
\text { Yes } \\
\text { Yes } \\
\text { Yes } \\
\text { Yes } \\
\text { Yes } \\
\text { Yes }\end{array}$ & $\begin{array}{l}21 \\
22 \\
17 \\
34 \\
17 \\
15 \\
41 \\
16\end{array}$ & $\begin{array}{l}\text { Pass } \\
\text { Pass } \\
\text { Pass } \\
\text { Pass } \\
\text { Pass } \\
\text { Pass } \\
\text { Pass } \\
\text { Pass }\end{array}$ & $\begin{array}{l}\text { Pass } \\
\text { Pass } \\
\text { Pass } \\
\text { Pass } \\
\text { Pass } \\
\text { Pass } \\
\text { Pass } \\
\text { Pass }\end{array}$ \\
\hline
\end{tabular}

Samples Distributed

May 10,2007

Reporting Data Received July 12, 2007

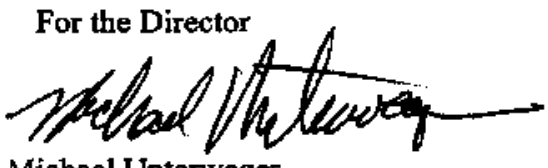

Michael Unterweger,

Acting Leader

Radioactivity Group

Physics Laboratory

(Continued) 


\section{DEPARTMENT OF ENERGY}

\section{LABORATORY ACCREDITATION PROGRAM}

\section{Summary Report}

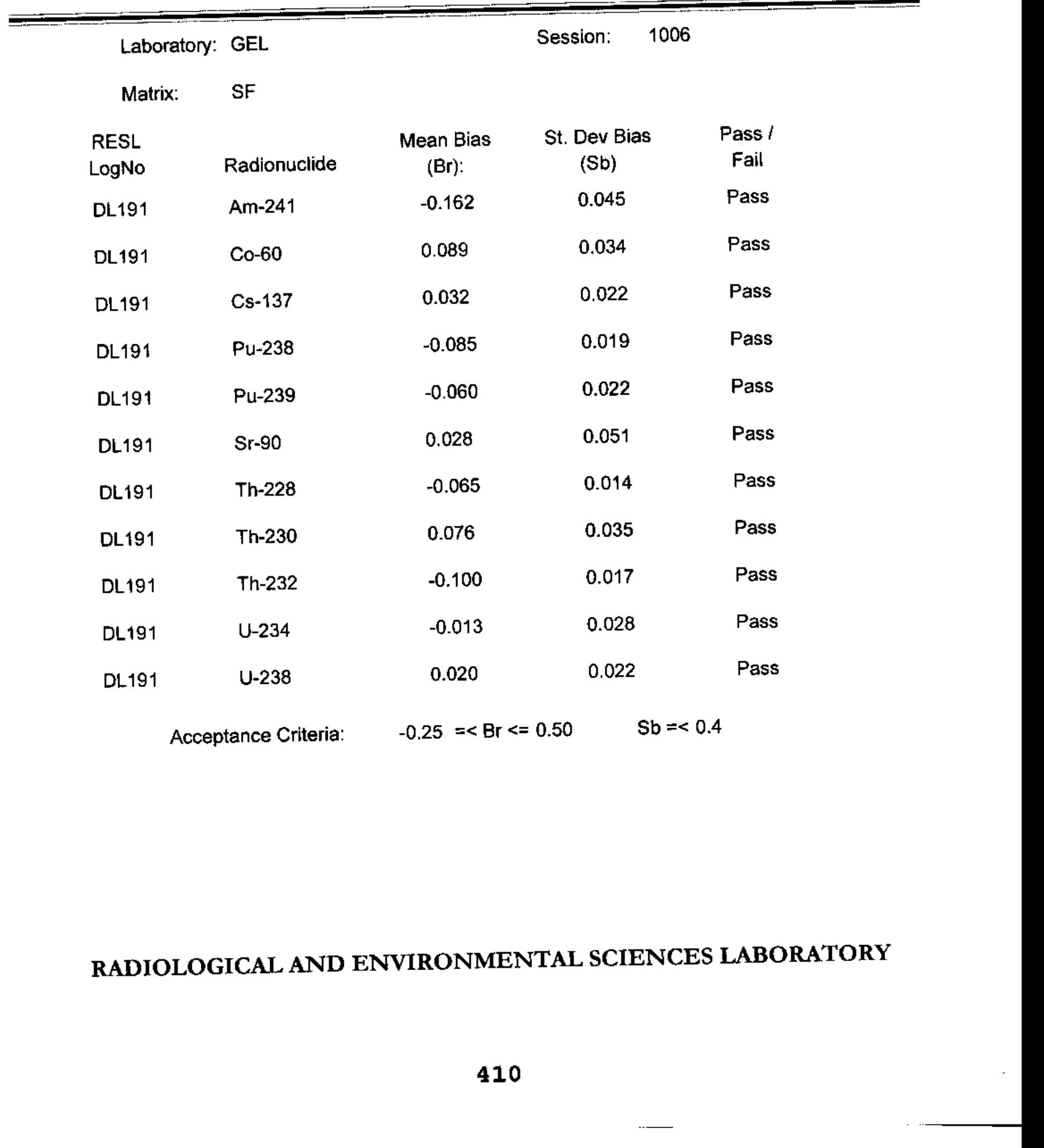




\section{ATTACHMENT 1}

\section{AUDIT SAMPLES}

(Historical File Only) 
From:

Sent:

To:

Cc:

Subject:

Attachments:
Swoboda, Robert G

Monday, July 07, 2008 12:06 PM

Antonio, Cheryl L

MacLellan, Jay; Carbaugh, Eugene H; Gieszler, Debbie L; Greenwood, Larry R

RE: Audit samples

RADREC_438-Pu-dil.XLS

Cheryl,

Preliminary data does indicate that there is some Am-241 contamination in my Pu-239 spike, but I am getting the same count rate $(\sim 20 \mathrm{cts} / 1000 \mathrm{~min})$ at the moment for Pu and Am which would only account for $\sim 0.02 \mathrm{dpm}$ equivalent Am-241. I too am glad that we have found at least a partial root cause. I want to quantify this source problem further, however this Pu-239 spike ( $W-145-3)$ is low on remaining volume. And it hails from a Malin Weiler prepared dilution legacy and had very long proven track record. I plan prepare a couple more direct mounts using most of the remaining $\sim 1-1.5 \mathrm{ml}$ of this spike and quantify the $\mathrm{Pu} / \mathrm{Am}$ ratio a little better. I am remembering using up a good portion of this spike directly in a previous round of standards checking done a couple years back.

I also had prepared a separate BA dilution level of Pu-239 --(R-438-f) material from an IPL source back in 2004 --- but I never implemented a switch based mainly on the consistent good performance of the W-145 --.- $0.5 \mathrm{dpm}$ std.

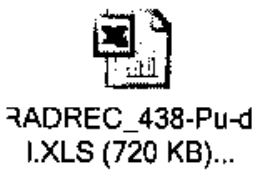

Btw - The Sr-90 spike directly mounted for AEA -- did not have any cts above bkg for 1000 min ct.

Thanks Bob --- 373-6089

\begin{tabular}{ll}
\hline From: & Antonio, Cheryl L \\
Sent: & Thursday, July 03, 2008 2:29 PM \\
To: & Swoboda, Robert G \\
Cc: & MacLellan, Jay; Carbaugh, Eugene H; Gieszler, Debbie L \\
Subject: & Audit samples \\
Importance: & High
\end{tabular}

Bob,

I think I might have good news for you, in a bad news way. We had you spike 5 samples in June with $0.02 \mathrm{dpm}$ Pu-239 and $10 \mathrm{dpm} \mathrm{Sr-90.} \mathrm{We} \mathrm{had} \mathrm{the} \mathrm{lab} \mathrm{analyze} \mathrm{the} \mathrm{samples} \mathrm{for} \mathrm{Pu-238,} \mathrm{Pu-239,} \mathrm{Am-241} \mathrm{and} \mathrm{Sr-90.} \mathrm{We} \mathrm{expected} \mathrm{results} \mathrm{less}$ than the decision level for Pu-238 and Am-241. The Pu-239, Pu-238 and Sr-90 results were within the acceptable range, but the Am-241 results were not blanks. The levels of Am-241 detected were consistent with what we were seeing in August 2007 through February 2008. Looking at the consistency of the results it really looks like either your Pu-239 or $\mathrm{Sr}-90$ tracer is contaminated, my money is on the Pu-239 tracer. The time has come to check your standards for Am-241 contamination. I am optimistic that we almost have this problem solved.

\begin{tabular}{ccccc}
$\begin{array}{c}\text { Sample } \\
\text { ID }\end{array}$ & $\begin{array}{c}\text { Sr-90 } \\
(\text { dpm })\end{array}$ & $\begin{array}{c}\text { Pu-239 } \\
(\text { dpm })\end{array}$ & $\begin{array}{c}\text { Pu-238 } \\
(\text { dpm })\end{array}$ & $\begin{array}{c}\text { Am-241 } \\
(\mathbf{d p m})\end{array}$ \\
\hline GEL080602 & 10.1 & 0.0204 & $<\mathrm{D}_{\mathrm{L}}$ & 0.0727 \\
GEL080603 & 8.18 & 0.0206 & $<\mathrm{D}_{\mathrm{L}}$ & 0.078 \\
GEL080604 & 8.84 & 0.0215 & $<\mathrm{D}_{\mathrm{L}}$ & 0.0667 \\
GEL080606 & 10.2 & 0.017 & $<\mathrm{D}_{\mathrm{L}}$ & 0.0861 \\
GEL080605 & 6.93 & 0.0154 & $<\mathrm{D}_{\mathrm{L}}$ & 0.0788
\end{tabular}


Thanks,

Cheryl 


\section{Antonio, Cheryl L}

From:

Sent:

To:

Cc:

Subject:

Attachments:
Swoboda, Robert G

Monday, August 04, 2008 2:17 PM

Antonio, Cheryl $L$

MacLellan, Jay

RE: Audit samples

Cheryl, RADREC_544-Pu-0.5dpm.XLS; RADREC_542-Am.XLS

Here's owe you a hard copy of these final reports.

Let me know if you'd like a $5 \mathrm{ml}$ ampoule of each for archive or for direct validation by GEL.

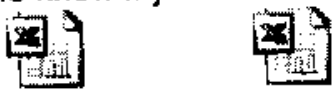

RADREC_544-PU-ORADREC_542-Am.

$.5 \mathrm{dpm} . \mathrm{XLS}(450 \ldots \quad \mathrm{XLS}(2 \mathrm{MB})$

Thanks Bob --- 373-6089

\begin{tabular}{ll}
\hline From: & Antonio, Cheryl L \\
Sent: & Monday, August 04, 2008 10:32 AM \\
To: & Swoboda, Robert G \\
Cc: & Gieszler, Debbie L; MacLellan, Jay \\
Subject: & FW: Audit samples
\end{tabular}

Bob, I haven't heard back from you yet. Debbie would like to go bring you samples tomorrow, are you ready to spike samples for americium-241, or should we just send you uranium samples and wait a bit on the plutonium and americium?

Thanks,

Cheryl

\begin{tabular}{ll}
\hline From: & Antonio, Cheryl L \\
Sent: & Tuesday, July 29, 2008 9:22 AM \\
To: & Swoboda, Robert G \\
Cc: & Gieszler, Debbie L; MacLellan, Jay \\
Subject: & Audit samples
\end{tabular}

Bob,

Next week we plan to send you 5 urine samples to be spiked with plutonium-239 only and another 5 samples to be spiked with plutonium-239 and americium-241. This will be in addition to the uranium samples. Do you think you will be ready for americium-241 sampling?

Debbie, these will be scheduled as AU001 etc.. 
From:

Sent:

To:

Cc:

Subject:
Greenwood, Larry R

Wednesday, June 04, 2008 4:30 PM

MacLellan, Jay

Swoboda, Robert G; Carbaugh, Eugene H; Antonio, Cheryl L

RE: Possibility of different lab space

Jay,

I will discuss this with Bob and my management and let you know what we can do. Given the relatively low cost of glassware, pipettes, etc, we should be able to dedicate equipment to this effort and/or use clean equipment for each preparation. Fume hood space should also be dedicated, if possible, or thoroughly cleaned prior to each prep. It is also possible to prepare blanks with each batch as a way of checking on contamination.

Larry Greenwood, Pacific Northwest National Laboratory

Laboratory Fellow

Phone: 509-376-6918, Fax: 509-373-6001

\begin{tabular}{ll}
\hline From: & MadLellan, Jay \\
Sent: & Wednesday, June 04, 2008 16:03 \\
To: & Greenwood, Larry R \\
Cc: & Swoboda, Robert G; Carbaugh, Eugene H; Antonio, Cheryl L \\
Subject: & Possibility of different lab space
\end{tabular}

Larry,

As you know, Bob Swoboda prepares audit samples for double blind submittal to the Hanford excreta bioassay contractor GEL as a key part of our QC oversight of GEL. In the past few months the Am-241 results from GEL have been consistently higher than the spike level Bob has reported to us. The problem seems to be limited to the samples from Bob's lab, as we are not seeing abnormal false-positive rates in our worker samples, and the GEL-originated lab control samples also don't show a problem. Last month we asked GEL to analyze for Am-241 a U spike Bob had prepared, and that result was a non-detect. We are taking that as a limited indication that the problem is not general contamination in Bob's lab. Bob and you have also checked his standard solutions and those showed the expected levels.

Bob has suggested that the problem may be trace contamination in his lab associated with higher level samples that have been processed there. If that is the case, it would appear to be specific to lab ware or equipment associated with spiking of urine samples with Pu and Am (they have only been done together for the last year). Can you think of any way to check for equipment contamination? The basic problem is we are asking Bob to spike at levels far below what is normally of concern in 325 . Bob has also expressed concern that future work planned for his lab may exacerbate the problem. His recommendation was that we inquire of you about the possibility of making alternate lab space available for our low-level audit sample preparation. If you can find new space, we may be able to fund some new lab ware and pipettes for a clean start.

\section{Jay MacLellan, CHP}

Radiation and Health Technology

Pacific Northwest National Laboratory

Phone: 509-376-7247

Fax: 509-376-8161

jay.maclellan@pnl.gov 
From:

Sent:

To:

Cc:

Subject:
Swoboda, Robert G

Thursday, June 05, 2008 2:24 PM

MacLellan, Jay

Carbaugh, Eugene H; Antonio, Cheryl L; Greenwood, Larry R

RE: Possibility of different lab space

Jay,

I am still perplexed as to how contamination could occur in my lab with the current controls I have in place --- there is little chance other than Chicken Little (falling out of air) that can cause contamination simply considering the very few cross contamination points--- let alone a consistent 3-4 times the $0.02 \mathrm{dpm}$ target activity during the timeframe of these audits. The only logical suspect seemed to be that the spike level was higher than expected target level - but this was investigated and found not to be the case. --- I again double checked my calculations on spike aliquots on audits in question and they were correct. (i.e. for Aug $2007 .-2 \mathrm{dpm} * 0.040 \mathrm{ml} /$

Pool of $4=0.02 \mathrm{dpm} / \mathrm{s}$.

Short of working in a clean plastic tent, I will re-place the following with new and again isolate:

-- Carboy for compositing

-- Pipette (replace end barrel) --- and obtain new box of tips

-- Water storage bottle and transferring container

-- Diaper paper working surface (always new)

-- this is it --- NOTHING else to isolate other that the passage of room air over the open containers.

Also,

-- I cleaned up the Quartz distiller several months ago and am now back on track using this double distilled water, although there is nothing wrong with nanopure system -- both came out comparable to BKG based on ICP-MS measurements.

-- I am archiving the last ampoule of current $2 \mathrm{dpm}$ standard -- this is available for you to send off to GEL if you wish.

--- I will do activity verification check on Am-241 intermediate standard -- then I will prepare a larger set of a new series of ampoulized standards at $0.5 \mathrm{dpm}$ (better level to provide larger spiking aliquot with more precision i.e. $0.02 \mathrm{dpm}=40 \mathrm{pl}$ )--and will replace with a new ampoule after every couple of uses.

I would also like to recommend that an occasional $10 \mathrm{X}--0.02 \mathrm{dpm}$ be requested (same for $\mathrm{Pu}$ ) --- this would help getting to potential root cause of problem.

FINAL Word --- I expect this contamination problem will go away but I do find it odd that this Am-241 contamination coincides time wise with a Pu-238 (this has the same AEA energy peak) incident from PNNL (could have extended somehow to my lab here (but I am dubious) or with associated bioassays sent out). Regardless, I am surprised that GEL did not have any problems with cross contamination @ $4.9 \mathrm{MeV}$ ROI.

Thanks Bob --- 373-6089 
From:

Sent:

To:

Cc:

Subject:
Swoboda, Robert G

Tuesday, July 01, 2008 10:42 AM

MacLellan, Jay

Carbaugh, Eugene H; Antonio, Cheryl L; Greenwood, Larry R

RE: TRIM: RE: Possibility of different lab space

Jay, I don't have all the BA samples in which the Am-241 data was high, but it does appear that for Aug, Oct, '07 and Jan '08 that Pu-239 was added @ $0.02 \mathrm{dpm}$ level to all samples and also that Sr-90 was added @ $10 \mathrm{dpm}$ level. So the possibility does exist. I will do a little investigating..... of both standards for Alpha@5.5 Mev.

-- stay tuned......

Thanks Bob -.- 373-6089

\begin{tabular}{ll}
\hline From: & Macletlan, Jay \\
Sent: & Friday, June 27, 2008 9:11 AM \\
To: & Swoboda, Robert G \\
Cc: & Carbaugh, Eugene H; Antonio, Cheryl L \\
Subject: & RE: TRIM: RE: Possibility of different lab space
\end{tabular}

Bob,

Anita Bhatt, the DOELAP administrator, was in town for another reason and Gene took the opportunity to ask her for unofficial thoughts concerning our problem. After some thought she asked if we had checked the Pu standard for Am contamination. Is that a possibility?

Jay MacLellan, CHP

Radiation and Health Technology

Pacific Northwest National Laboratory

902 Battelle Boulevard

Richland, WA 99352-USA

P.O. Box 999, MSIN BI-60

Phone: 509-376-7247

Fax: 509-376-8161

jay.maclellan@pnl.gov

Www.pnl.cov

From: MacLellan, Jay

Sent: Thursday, June 05, 2008 2:37 PM

To: Swoboda, Robert G

Cc: Carbaugh, Eugene H; Antonio, Cheryl L; Greenwood, Larry $\mathrm{R}$

Subject: TRIM: RE: Possibility of different lab space

Bob,

It is perplexing to us all. There doesn't appear to be gross wide-spread contamination (nothing in the blanks), and the high bias of the results has been rather consistent. I also double checked your calculations and didn't find any errors. We have been leaning toward a contaminated pipette, but I would have guessed the bias from that cause would be more variable. Consistent double or triple spiking of the samples would explain the problem, but that doesn't seem probable. I'll leave it to you and Cheryl to work through the practicality of some high level spikes. Gene will be back on Monday, and may also have additional thoughts.

As with many aspects of our work the shotgun approach may be the only recourse, and an identified cause may continue to elude us. 


\title{
Jay MacLellan, CHP
}

Radiation and Health Technology

Pacific Northwest National Laboratory

Phone: 509-376-7247

Fax: 509-376-8161

jay.maclellan@pnl.gov

\author{
From: Swoboda, Robert $\mathrm{G}$ \\ Sent: Thursday, June 05, 2008 2:24 PM \\ To: MacLellan, Jay \\ Cc: Carbaugh, Eugene H; Antonio, Cheryl L; Greenwood, Larry R \\ Subject: RE: Possibility of different lab space
}

Jay,

I am still perplexed as to how contamination could occur in my lab with the current controls I have in place -- there is little chance other than Chicken Little (falling out of air) that can cause contamination simply considering the very few cross contamination points--- let alone a consistent 3-4 times the $0.02 \mathrm{dpm}$ target activity during the timeframe of these audits. The only logical suspect seemed to be that the spike level was higher than expected target level -- but this was investigated and found not to be the case. --- I again double checked my calculations on spike aliquots on audits in question and they were correct. (i.e. for Aug 2007 -- $2 \mathrm{dpm}{ }^{*} 0.040 \mathrm{ml} /$

Pool of $4=0.02 \mathrm{dpm} / \mathrm{s}$ )

Short of working in a clean plastic tent, I will re-place the following with new and again isolate:

-- Carboy for compositing

- Pipette (replace end barrel) -.- and obtain new box of tips

-- Water storage bottle and transferring container

-- Diaper paper working surface (always new)

-- this is it --- NOTHING else to isolate other that the passage of room air over the open containers.

Also,

-- I cleaned up the Quartz distiller several months ago and am now back on track using this double distilled water, although there is nothing wrong with nanopure system -- both came out comparable to BKG based on ICP-MS measurements.

- I am archiving the last ampoule of current $2 \mathrm{dpm}$ standard --. this is available for you to send off to GEL if you wish. - I will do activity verification check on Am-241 intermediate standard --- then I will prepare a larger set of a new series of ampoulized standards at $0.5 \mathrm{dpm}$ (better level to provide larger spiking aliquot with more precision i.e. $0.02 \mathrm{dpm}=40 \mathrm{\mu l}$ )--and will replace with a new ampoule after every couple of uses.

I would also like to recommend that an occasional $10 \mathrm{X}--0.02 \mathrm{dpm}$ be requested (same for $\mathrm{Pu}$ ) --- this would help getting to potential root cause of problem.

FINAL Word -- I expect this contamination problem will go away but I do find it odd that this Am-241 contamination coincides time wise with a PU-238 (this has the same AEA energy peak) incident from PNNL (could have extended somehow to my lab here (but I am dubious) or with associated bioassays sent out). Regardless, I am surprised that GEL did not have any problems with cross contamination @ $4.9 \mathrm{MeV}$ ROI.

Thanks Bob --- 373-6089

\begin{tabular}{ll}
\hline From: & Greenwood, Larry R \\
Sent: & Wednesday, June 04, 2008 4:30 PM \\
To: & MacLellan, Jay \\
Cc: & Swoboda, Robert G; Carbaugh, Eugene H; Antonio, Cheryl L \\
Subject: & RE: Possibility of different lab space
\end{tabular}

Jay,

I will discuss this with Bob and my management and let you know what we can do. Given the relatively low cost of 
glassware, pipettes, etc, we should be able to dedicate equipment to this effort and/or use clean equipment for each preparation. Fume hood space should also be dedicated, if possible, or thoroughly cleaned prior to each prep. It is also possible to prepare blanks with each batch as a way of checking on contamination.

Larry Greenwood, Pacific Northwest National Laboratory

Laboratory Fellow

Phone: 509-376-6918, Fax: 509-373-6001

\begin{tabular}{ll}
\hline From: & Macl.ellan, Jay \\
Sent: & Wednesday, June 04, 2008 16:03 \\
To: & Greenwood, Larry R \\
Cc: & Swoboda, Robert G; Carbaugh, Eugene H; Antonio, Cheryl L \\
Subject: & Possibility of different lab space
\end{tabular}

Larry,

As you know, Bob Swoboda prepares audit samples for double blind submittal to the Hanford excreta bioassay contractor GEL as a key part of our QC oversight of GEL. In the past few months the Am-241 results from GEL have been consistently higher than the spike level Bob has reported to us. The problem seems to be limited to the samples from Bob's lab, as we are not seeing abnormal false-positive rates in our worker samples, and the GEL-originated lab control samples also don't show a problem. Last month we asked GEL to analyze for Am-241 a U spike Bob had prepared, and that result was a non-detect. We are taking that as a limited indication that the problem is not general contamination in Bob's lab. Bob and you have also checked his standard solutions and those showed the expected levels.

Bob has suggested that the problem may be trace contamination in his lab associated with higher level samples that have been processed there. If that is the case, it would appear to be specific to lab ware or equipment associated with spiking of urine samples with Pu and Am (they have only been done together for the last year). Can you think of any way to check for equipment contamination? The basic problem is we are asking Bob to spike at levels far below what is normally of concern in 325 . Bob has also expressed concern that future work planned for his lab may exacerbate the problem. His recommendation was that we inquire of you about the possibility of making alternate lab space available for our low-level audit sample preparation. If you can find new space, we may be able to fund some new lab ware and pipettes for a clean start.

\section{Jay MacLellan, CHP}

Radiation and Health Technology

Pacific Northwest National Laboratory

Phone: 509-376-7247

Fax: 509-376-8161

jay.maclellan@pnl.gov 
From:

Sent:

To:

Cc:

Subject:

Attachments:
Swoboda, Robert G

Friday, July 25, 2008 2:14 PM

Antonio, Cheryl L

Soderquist, Chuck Z; Swoboda, Robert G

RE: Am-241 evaluation

RADREC_544-Pu-0.5dpm.XLS; RADREC_542-Am.XLS

Cheryl, I prep'd a new series (10 ampoules @ 5mL each) of Am-241 and Pu-239 @ $0.5 \mathrm{dpm}$ and am re-verifying activity and purity of intermediate parent --- still awaiting data form counting room. The Sr-90 R-444-b standard showed no alpha above bkg upon AEA counting of

Due to 1yr expiration on opened ampoules usage I will be breaking into a new source material R-484 (series prep) --- I will check an aliquot of this standard upon opening for purity.

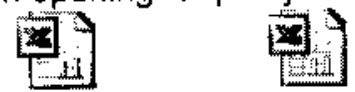

RADREC_544-PU-ORADREC_542-Am. $.5 \mathrm{dpm} . X \mathrm{XS}(452 \ldots \quad$ XLS (2 MB)

Here are temporary prep records---

Btw-- the W-145-3 Pu-239 material got counted for $7200 \mathrm{~min}$ and the Am-241/Pu-238 ROI is about $1.5-2$ times the Pu-239 ROI -.. Chuck and I looked and evaluated the spectral data -- I will send out a formal report. This only accounts for $\sim 1 / 2$ the Am-241 you were seeing in the audits, but hopefully with all the new standards and change out again of all associated equip \& materials, we will be $\mathrm{OK}$ in future.

Thanks Bob --- 373-6089

\begin{tabular}{ll}
\hline From: & Antonio, Cheryl L \\
Sent: & Thursday, July 24, 2008 1:23 PM \\
To: & Swoboda, Robert G \\
Cc: & MacLellan, Jay \\
Subject: & RE: Am-241 evaluation
\end{tabular}

Bob, we are getting ready to send another batch of samples to you for spiking. What is the status of Am-241? Also, I may have missed an email but have you checked the strontium source for potential cross contamination? All of the samples since August were spiked with $\mathrm{Pu}-239$ and $\mathrm{Sr}-90$.

Take care,

Cheryl

\begin{tabular}{ll}
\hline From: & Swoboda, Robert G \\
Sent: & Thursday, July 17, 2008 11:53 AM \\
To: & Soderquist, Chuck Z \\
Cc: & Trang-Le, Truc T, Antonio, Cheryl L \\
Subject: & Am-241 evaluation
\end{tabular}

Chuck,

Can you evaluate the Pu-239 (W-145-3-a,b,c) direct plated loooooow level source checks that are just finishing counting on our new AEA detectors for Am-241/Pu-238 corresponding activity.. All I really need is a good ratio of the 2 energies so I can get a good idea of exactly the maximum contamination was contributed by this source. The Pu-239 activity should be @ $0.2 \mathrm{ml}^{*} 0.54 \mathrm{dpm} / \mathrm{ml}=1.08 \mathrm{dpm}$. I think the AEA efficiencies are based on co-ppt geometries so l expect nominal total recovery to be greater than $100 \%$.

I am not seeing the same relative levels of Am-241 as BAQC program folks are seeing so I need secondary input on this concern.

Charge your time to K99326 for this effort.----

Thanks Bob -.- 373-6089 
